Maria Fernanda Malaman

\title{
Avaliação diagnóstica do exantema máculo- papular e urticária tardia induzidos por antibióticos beta-lactâmicos
}

Tese apresentada à Disciplina de Imunologia Clínica e Alergia da Faculdade de Medicina da Universidade de São Paulo para obtenção do título de Doutor em Ciências

Área de concentração: Imunologia Clínica e Alergia

Orientador: Prof. Dr. Fabio Fernandes Morato Castro

São Paulo

2006 
Aos meus pais, Marilene e Sergio

Aos meus irmãos, Silvia e Paulo Ao meu grande companheiro, Sergio 


\section{Agradecimentos}

Aos meus pais, Marilene e Sergio, que me guiaram gentil e sabiamente pela vida e que serão sempre meus mentores.

Aos meus irmãos, Silvia e Paulo, por estarem sempre ao meu lado.

Ao meu marido, Sergio: Sem seu apoio e compreensão, este trabalho não seria possível. Obrigada por seu carinho durante esta difícil jornada.

Ao Prof. Jorge Kalil pela oportunidade.

Ao meu orientador, Prof. Fabio Castro: um empreendedor. Obrigada pela confiança e pela liberdade durante a realização deste trabalho.

Ao meu co-orientador, Prof. Abílio Motta pelo estímulo constante.

Aos amigos: Profa. Inês Camelo Nunes, Prof. Flavio Sano, Prof. Clóvis Galvão pelas ricas sugestões durante a fase embrionária deste projeto.

À Dra. Cristina Kokron pelo empenho na realização dos experimentos laboratoriais e valiosa contribuição.

À Tânia, pelo apoio e esforço sem tamanho para finalizar este trabalho.

À equipe do LIM-60: Anete, Ruth, Carlos, Elza, Santa e Sergio. Pela boa vontade e incrível capacidade técnica.

Aos funcionários do ambulatório de Imunologia Clínica e Alergia da Faculdade de Medicina da Universidade de São Paulo: Leoni, Serafin, Hilário, Rosana, Genair.

Ao Dr. João Ferreira de Mello e Wilson Tartuce Aun pelo estímulo no estudo das reações adversas a drogas desde o início da minha formação profissional.

Aos meus amigos do Hospital do Servidor Público Estadual de São Paulo por acreditarem sempre em mim.

Ao Dr. Franklin Adkinson do Johns Hopkins Asthma and Allergy Center, Baltimore, MD, USA pela idéia deste projeto e pelas valiosas opiniões durante sua realização.

À Fapesp, pelo apoio e financiamento deste projeto.

Aos meus pacientes. 


\section{Sumário:}

Lista de abreviaturas

Lista de Tabelas

Resumo

Summary

I. Introdução. $\ldots 1$

II. Objetivos .12

III. Revisão de

literatura

1. Classificações das reações a antibióticos $\beta$ -

lactâmicos 13

2. Imunopatologia das reações tardias a

medicamentos 20

3. Processamento e Apresentação do

Antígeno. 23

4. Resposta T

helper. .27

5. O Envolvimento das Celulas

$\mathrm{T}$. 30

6. Fatores de risco associados às reações imunológicas a drogas......34 
IV. Justificativa.

36

V. Métodos

38

1. Origem da população de

estudo. .38

2. Definições

Operacionais .38

3. Critérios de

Inclusão .39

4. Critérios de Exclusão

39

5. Identificação dos Pacientes e

Recrutamento 40

6. Estudos

Imunológicos 40

a. Teste de hipersensibilidade

imediata. .40

b. Pesquisa in vitro de IgE específica a penicilina, amoxacilina e ampicilina. .42 
c. Testes de hipersensibilidade tardia: teste de contato e intradérmico

43

d. Proliferação Linfocitária

45

e. Dosagem de

citocinas .51

VI. Análise

estatística .55

VII. Resultados

56

1. Características

demográficas. .56

2. Testes cutâneos de leitura

imediata .58

3. Testes cutâneos de leitura tardia: intradérmico e de contato 58

4. Determinação sérica de $\lg E$ específica in vitro. 61

5. Proliferação

linfocitária..... 62

6. Dosagem de citocinas no sobrenadante da cultura de linfócitos.......76 
VIII. Discussão

78

IX.

Conclusões. .84

X. Referências

Bibliográficas. .85

XI. Bibliografia

consultada. .94

XII. Anexos. .1 00

\section{Lista de Figuras:}

Figura 1a: Estrutura química dos antibióticos beta-

lactâmicos. 8

\section{Figura 1b:}

Aminopenicilinas... .9

Figura 2 a e 2b: montagem da placa para cultura linfocitária. .50 
Figura 3a: Aspecto final da placa para dosagem de TNF-alfa no sobrenadante da cultura linfocitária. .53

Figura 3b: Aspecto final da placa para dosagem de IL-5 no sobrenadante da cultura

linfocitária. .54

Figura 4a: Paciente APG - leitura de 48h teste cutâneo intradérmico positivo para ampicilina, amoxicilina e penicilina. .59

Figura 4b: Paciente RCL - leitura de 72 horas teste intradérmico positivo para ampicilina, amoxicilina e penicilina .59

Figura 4c: Paciente WOF - leitura 72 horas teste intradérmico positivo para ampicilina, amoxicilina e penicilina .60

Figura 5a: Paciente $\mathrm{RCL}$ - teste de contato leitura de 72 horas positivo para ampicilina, amoxicilina penicilina. .60

Figura 5b: Paciente WOF - leitura 72 horas teste de contato positivo para ampicilina, amoxicilina e penicilina. 61

Figura 6a: Média do índice de estimulção (I.E.) na proliferação linfocitária com ampicilina em diferentes concentrações: Pacientes $X$ Controles .66 
Figura 6b: Média do índice de estimulção (I.E.) na proliferação linfocitária com amoxicilina em diferentes concentrações: Pacientes $X$ Controles 69

Figura 6c: Média do índice de estimulção (I.E.) na proliferação linfocitária com penicilina em diferentes concentrações: Pacientes $\mathrm{X}$ Controles 71

\section{Lista de Tabelas:}

Tabela 1: Classificação Imunopatológica das Reações Alérgicas a Medicamentos .4

Tabela 2: Relação entre apresentação clínica e tipos de hipersensibilidade....19

Tabela 3: Resultados da detecção de $\lg E$ sérica específica. .43

Tabela 4: Características populacionais baseadas nas respostas obtidas pela aplicação do questinário do JHAAC .57

Tabela 5a: Média do índice de proliferação com ampicilina em diferentes concentrações, desvio padrão e comparação entre pacientes e controles....63

Tabela 5b: Média do índice de proliferação com amoxicilina em diferentes concentrações, desvio padrão e comparação entre pacientes e controles......64 
Tabela 5c: Média do índice de proliferação com penicilina em diferentes concentrações, desvio padrão e comparação entre pacientes e controles....65

Tabela 6a: Sensibilidade, especificidade, valor preditivo positivo e negativo da proliferação linfocitária com ampicilina em diferentes concentrações .75

Tabela 6b: Sensibilidade, especificidade, valor preditivo positivo e negativo da proliferação linfocitária com amoxicilina em diferentes concentrações 75

Tabela 6c: Sensibilidade, especificidade, valor preditivo positivo e negativo da proliferação linfocitária com pencicilina em diferentes concentrações .75

Tabela 7 a: Sensibilidade, especificidade, valor preditivo positivo e negativo da dosagem de IFN-gama no sobrenadante da cultura linfocitária. .76

Tabela 7b: Sensibilidade, especificidade, valor preditivo positivo e negativo da dosagem de TNF-alfa no sobrenadante da cultura linfocitária. .77

Tabela 7c: Sensibilidade, especificidade, valor preditivo positivo e negativo da dosagem de IL-5 no sobrenadante da cultura linfocitária. .77

Tabela 8a: Resultados dos testes cutâneos de leitura tardia, teste de contato, proliferação linfocitária, IgE sérica específica, dosagem de citocinas 
no sobrenadante da cultura linfocitária (pacientes

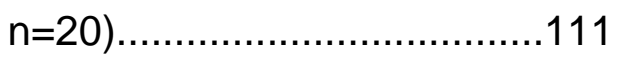

Tabela 8a: Resultados dos testes cutâneos de leitura tardia, teste de contato, proliferação linfocitária, IgE sérica específica, dosagem de citocinas no sobrenadante da cultura linfocitária (controles $n=15)$ 112

Lista de abreviaturas: 
AMX: amoxicilina

AMP: ampicilina

PEN: penicilina

LTT: lymphocyte transformation test

PPL: peniciloil polilisina

MDM: mistura de determinantes menores

RAD: reações adversas a drogas

I.E.: índice de estimulação

Ig: imunoglobulina

AINH: antinflamatórios não hormonais

LES: lupus eritematoso sistêmico

FcєRI: receptor de alta afinidade para $\lg E$

TCR: receptor de células T

Células Th1: linfócitos T helper (auxiliares) tipo1

Células Th2: linfócitos T helper (auxiliares) tipo2

IFN- $\gamma$ : interferon gama

TNF- $\alpha$ : fator de necrose tumoral alfa

IL: interleucina

CD: cluster differentiation

CTL: células citotóxicas

ADCC: citotoxicidade celular dependente de anticorpos

NK: natural killer

MHC: complexo principal de histocompatibilidade

LMP: grandes partículas proteolíticas multicatalíticas 
TAP: transportadores associados a apresentação antigênica MDR: transportadores resistentes a multidrogas

NET: necrólise epidérmica tóxica

APC: célula apresentadora de antígeno 


\section{Summary:}

The beta-lactam antibiotic, mainly aminopenicillins: ampicillin (AMP) and amoxicillin (AMX), are frequently cited as causes of morbiliforme eruptions and late onset urticaria. A major problem with existing data on beta-lactam reactions of the delayed type includes a lack of standardized testing methods. Objectives: The goal of this study is to establish the frequency and significance of positive skin testing in patients with history of beta-lactam induced maculo-papular exanthema and late onset urticaria and the sensibility/specificity of in vitro tests for drug allergy investigation: lymphocyte proliferation assay and cytokine detection. Methods: Patients were submitted to complete penicillin (PEN) allergy test: specific detection for serum IgE antibody to benzyl penicilloyl polylysine, amoxicilloyl polylysine and ampicilloyl polylysine; puncture and intradermal skin test with benzyl penicilloyl polylysine and minor determinants mixture, benzylpenicillin (10.000 Ul/ml), amoxicillin $(2 \mathrm{mg} / \mathrm{ml})$, ampicillin $(2 \mathrm{mg} / \mathrm{ml})$ were performed and read at 20 minutes, 48 hours and 72 hours. All patients had epicutaneous patch testing done with the same drugs (5\% amoxicillin, $5 \%$ ampicillin and $5000 \mathrm{IU} / \mathrm{g}$ penicillin $\mathrm{G}$ all in petrolatum). All tests were performed in duplicate with positive and negative controls. All subjects had blood collected for lymphocyte proliferation assay ( $\mathrm{H}^{3}$-thymidine incorporation assay) and IL-5, TNF-alpha and IFN-gamma profile were analyzed in culture supernatant by ELISA. Results: None of the patients or controls had positive immediated skin test. Only three patients reacted positively to the 48 and 72 hours 
reading of intradermal skin test and patch test with the same reagents. There was no positive skin test result among the control group. The lymphocyte proliferation test (LTT) was positive in only two control subjects, while in the study group, 10 patients had positive proliferation tests (50\%). The LTT sensitivity varied from $25 \%$ to $55 \%$ depending on the drug and concentration tested. The specificity ranged from $80 \%$ to $100 \%$. IFN-gamma and IL-5 detection had a high specificity, but low sensitivity, while TNF-alpha showed high sensitivity (95\%) and low specificity (40\%). 


\section{Resumo:}

Os antibióticos beta-lactâmicos, principalmente as aminopenicilinas (ampicilina e amoxicilina) são causa freqüente de exantema maculo papular e urticária tardia em pacientes tratados com estes medicamentos. Entretanto, a falta de métodos para diagnóstico destas reações constitui uma lacuna na abordagem destes indivíduos. Objetivos: Os objetivos deste estudo foram determinara a freqüência e significância de testes cutâneos positivos em pacientes com história de exantema maculo-papular e urticária tardias induzidos por antibióticos beta-lactâmicos e determinar a sensibilidade e especificade dos testes diagnósticos in vitro para o diagnóstico de alergia a drogas: proliferação linfocitária e dosagem de citocinas no sobrenadante da cultura linfocitária.. Métodos: Os pacientes foram submetidos à dosagem de IgE específica para os seguintes determinantes: benzilpeniciloil, amoxiciloil e ampiciloil. Testes cutâneos de puntura e intradérmico com benzilpeniciloil polilisina, mistura de determinantes menores da penicilina, benzilpenicilina (10.000 $\mathrm{Ul} / \mathrm{ml})$, amoxicilina $(2 \mathrm{mg} / \mathrm{ml})$ e ampicilina $(2 \mathrm{mg} / \mathrm{ml})$ foram realizados em todos os pacientes com leituras após 20 minutos, 48 horas e 72 horas. Foi realizado teste de contato com os mesmos medicamentos (amoxicilina 5\%, ampicilina 5\% e penicilina G 5000Ul/g de vaselina sólida). Todos os testes foram feitos em duplicata com controles positivo e negativo. Amostras de sangue foram coletadas para a proliferação linfocitária (incorporação de timidina triciada) e dosagem de citocinas no sobrenadante da cultura (IL-5, IFN-gama e TNF- 
alfa) através de ELISA. Resultados: Foram estudados 20 pacientes e 15 controles. Nenhum dos pacientes ou controles apresentou teste cutâneo de leitura imediata positivo. Três pacientes reagiram positivamente aos testes cutâneos de leitura tardia nas leituras de 48 e 72 horas. Não houve nenhum resultado positivo dos testes cutâneos no grupo controle. A proliferação linfocitária mostrou-se positiva em somente 2 controles (13\%) e 10 pacientes (50\%). A sensibilidade dos experimentos de proliferações linfocitária variou entre $25 \%$ com penicilina na concentração de $250 \mu \mathrm{g} / \mathrm{ml}$ até $55 \%$ com ampicilina $1000 \mu \mathrm{g} / \mathrm{ml}$. Sua especificidade foi de $80 \%$ a $100 \%$.

Conclusão: os testes cutâneos de leitura tardia não constituíram métodos diagnósticos eficazes para as reações tardias aos antibióticos betalactâmicos. A proliferação linfocitária apresentou baixa sensibilidade, porém, alta especificidade para o diagnóstico das mesmas reações. A detecção de IFN-gama e IL-5 evidenciaram alta especificidade e baixa sensibilidade, enquanto a dosagem de TNF-alfa mostrou-se altamente sensível (95\%), porém, pouco específica $(40 \%)$. 


\section{Introdução:}

Reações adversas a medicamentos constituem um problema comum na prática médica diária. A avaliação de uma provável reação adversa e identificação da droga implicada é uma tarefa sempre difícil. Estima-se que 5 a $10 \%$ dos pacientes desenvolvam reações adversas a alguma medicação durante o curso do tratamento (Weiss, 1998). Cerca de $30 \%$ dos pacientes hospitalizados experimentam ao menos uma reaçãoo adversa a droga (Hunziker, 1997) . Aproximadamente 3\% de todas as admissões em serviços médicos de emergência e $0,3 \%$ de todas as admissões hospitalares são atribuídas a reações adversas a medicações (Hunziker, 1997). Reações fatais ocorrem em $0,1 \%$ dos pacientes clinicos internados e $0,01 \%$ dos pacientes cirúrgicos (De Swarte, 1989).

As Reações Adversas a Medicamentos podem ser divididas em Previsíveis e Imprevisíveis. As primeiras podem ocorrer em qualquer indivíduo e incluem: (De Swarte, 1989; Hunziker, 1997)

1. Overdose: reações tóxicas causadas por doses excessivas da droga ou comprometimento no mecanismo de excreção e/ou metabolização da mesma ;

2. Efeito colateral: constituem efeitos indesejáveis, porém, potencialmente inevitáveis uma vez que decorrem do efeito farmacológico de uma determinada medicação, como exemplo os tremores causados pelo uso dos $\beta-2$ agonistas; 
3. Efeitos secundários: são efeitos indesejáveis não relacionados a ação farmacológica primária da droga, como candidiase oral com o uso de corticosteróides inalatórios;

1.4. Interação Medicamentosa: envolve a interação de dois ou mais medicamentos causando toxicidade que de outra forma não ocorreria, um bom exemplo seria a toxicidade cardiológica pelo uso concomitante de terfenadina e eritromicina.

Outros tipos de reações só ocorrem em pacientes susceptíveis e, portanto, são imprevisíveis. Deste grupo fazem parte:

1. Intolerância: decorrente de uma baixa tolerância a ação farmacológica normal de uma droga, como tinnitus após uso de baixas doses de salicilatos em alguns pacientes;

2. Idiossincrasia: geralmente causadas por alterações metabólicas geneticamente determinadas ou deficiência enzimática que não se expressa sob situações normais, como anemia hemolítica em pacientes com deficiência de glucose-6-fosfato desidrogenase após uso de uma droga oxidante;

3. Reações Alérgicas: por definição envolvem um mecanismo imunológico caracterizado pela especificidade, possibilidade de transferência de anticorpos ou linfócitos sensibilizados, e recorrência do quadro numa possível re-exposição. Contribuem com 5 a $10 \%$ das reações adversas a medicamentos.

4. Reações Pseudo-alérgicas: são aquelas que possuem apresentação clínica semelhante às reações alérgicas (como por 
exemplo, a liberação de histamina), mas cujo mecanismo não envolve células imunes efetoras (anticorpos ou linfócitos sensibilizados). 
Tabela 1: Classificação Imunopatológica das Reações Alérgicas a Medicamentos

Classificação

Tipo I

Tipo II

Tipo III

Tipo IV

\section{Reação}

Hipersensibilidade Imediata

IgE mediada

Anafilaxia, Urticária,

Angioedema, alguns

Exantemas

Reações Citotóxicas

$\lg \mathrm{G}$ e $\lg \mathrm{M}$ mediadas

Citopenias, algumas

Vasculites

Reações por Imunocomplexos IgG e IgM mediadas

Doença do Soro,

Vasculites

Reações Mediadas por Linfócitos Sensibilidade por Contato, Exantema Inflamação em órgãos

Classificação didática das reações imunológicas a drogas baseada na classificação dos tipos de hipersensibilidade descritos por Gell \& Coombs e exemplos clínicos. 
A maior parte das RAD não envolve mecanismos imunológicos específicos. Historicamente, as reações imunológicas a drogas foram descritas no contexto da classificação de Gell e Coombs (tabela 1). Este modelo continua a ser útil clinicamente em algumas situações. De fato, a demonstração da presença de anticorpos $\lg E$ penicilina-específicos no contexto de uma história clínica compatível, possui um importante valor preditivo. Este tipo de abordagem, porém, tem valor limitado quando aplicado a outras drogas como AINH (antiinflamatórios não hormonais), contrastes iodados e opióides onde as reações podem se apresentar como urticária, angioedema, broncoespasmo, etc, indistinguíveis de uma reação anafilática mediada por $\lg \mathrm{E}$, embora não requeiram sensibilização e não pareçam constituir antígenos completos ou haptenos alergênicos. As reações alérgicas a drogas mimetizam muitas doenças como infecções virais, (hepatite e exantema), doenças auto-imunes (LES e trombocitopenia), discrasias sanguíneas (agranulocitose), doenças neurológicas agudas (Sd. De Guillain-Barre), graves doenças cutâneas (bollhosas, necrólise epidérmica tóxica), doenças intersticias pulmonares e renais, febre isoladamente, vasculites, etc.

Pacientes com reações incomuns são geralmente diagnosticados como infecções virais, doenças autoimunes ou idiopáticas. Uma causa alérgica para uma hepatite grave, febre, linfadenopatia é ainda muito difícil de ser suspeitada para a maioria dos clínicos e, na muitas vezes, o diagnóstico é retardado. Além disso, as doenças induzidas por drogas podem nos ensinar muito sobre a fisiopatologia da doença original. 
Identificar corretamente qual é o medicamento responsável pela reação é sempre um desafio. Na maioria dos casos, múltiplas medicações estão em uso concomitante, e as manifestações clínicas se sobrepõem às da doença de base. Um exemplo comum é do paciente que desenvolve exantema, sendo difícil diferenciar o viral daquele causado por antibiótico.

A falta de conhecimento atual sobre a imunoquímica do metabolismo das drogas e a imunoreatividade de seus metabólitos compromete muito nossa habilidade em utilizar procedimentos diagnósticos para a avaliação destas reações. Exceto pela penicilina e, em menor grau, anticonvulsivantes e sulfonamidas, nossa compreensão permanece um tanto limitada. Atualmente são utilizados alguns testes a fim de avaliar a resposta imune especifica a drogas, porém não sabemos ainda os reais valores preditivos positivos e negativos destes procedimentos diagnósticos. Este fato é compreensível uma vez que existem poucos estudos onde um número grande de pacientes com resultados positivos e negativos tenham sido submetidos à provocação com a droga suspeita.

Apesar de todas estas dificuldades, o empenho em elucidar o correto diagnóstico é de extrema importância, principalmente no que concerne ao uso futuro de outras medicações e manejo correto da atual reação. Rotular um indivíduo equivocadamente de alérgico a uma determinada medicação é de grande responsabilidade, uma vez que pode implicar no uso futuro de drogas mais tóxicas e menos eficazes como substitutos à medicação de escolha. 
Estudos epidemiológicos mostram que a lesão cutânea mais freqüente envolvida nestes eventos é o exantema máculo-papular, podendo ocorrer entre 56 e $91 \%$ dos casos, seguido pela urticária e vasculites cutâneas (Bachot, 2003; Bibby, 2001; Adkinson, 1998; Romano, 2004). Os antibióticos do grupo das penicilinas são os medicamentos mais comumente relacionados a estas reações (44 a 54\%) (Adkinson, 1984; Fiszenson-Albala, 2003; Hunziker, 1997; Rademarker, 1995).

Um estudo brasileiro publicado em 2000 (Malaman, 2000) mostrou que, em pacientes ambulatoriais, as aminopenicilinas foram a segunda causa mais comum de reação adversa a drogas e que a lesão cutânea mais relacionada a estes grupo de medicamentos, foi o exantema máculo-papular. Em 2004, Dracoulakis e colaboradores estudou 44 casos de pacientes internados com quadro de reação adversa a medicamentos e constatou que os antibióticos beta-lactâmicos foi a droga mais comumente envolvida e a lesão cutânea mais comum foi o exantema máculo-papular.

Os antibióticos do grupo dos beta-lactâmicos são os principais antibióticos prescritos em decorrência de sua eficácia e segurança. Entretanto, uma das desvantagens destes medicamentos é a alta incidência de reações alérgicas. Os sintomas são muito variáveis incluindo: urticária, anafilaxia, citopenias, vasculites e exantemas. As penicilinas, assim como as aminopenicilina, cefalosporinas, carbapenens e monobactans, são denominadas beta-lactâmicos pela presença de um anel beta-lactâmico comum em sua estrutura química (figura 1a e 1b). 


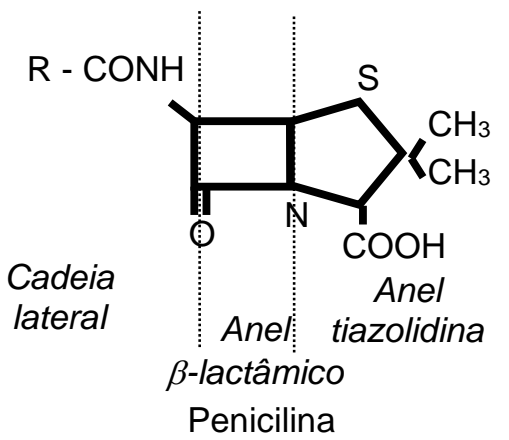

Penicilina

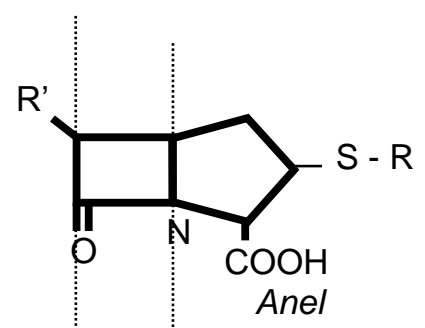

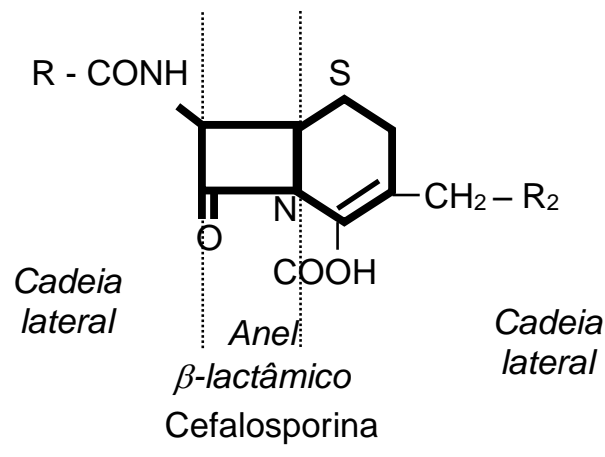

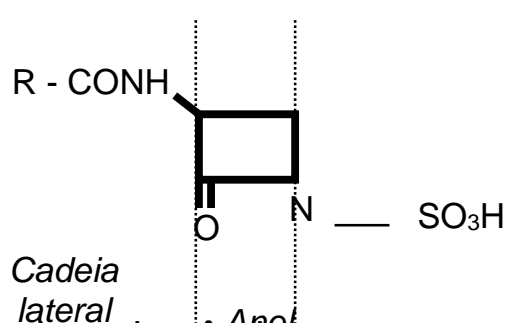

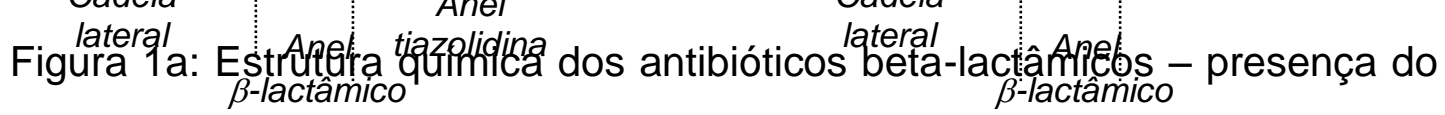

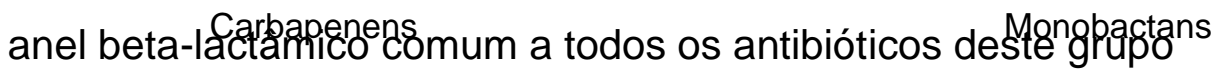

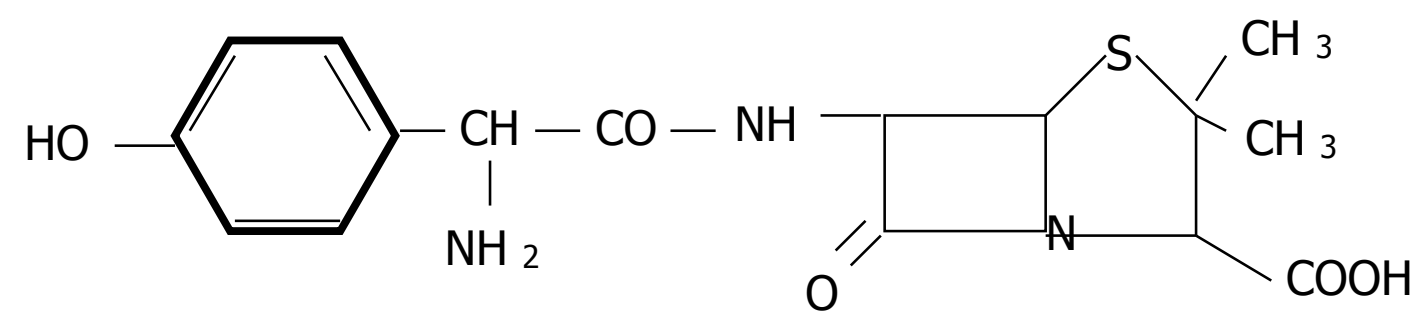

Amoxicilina
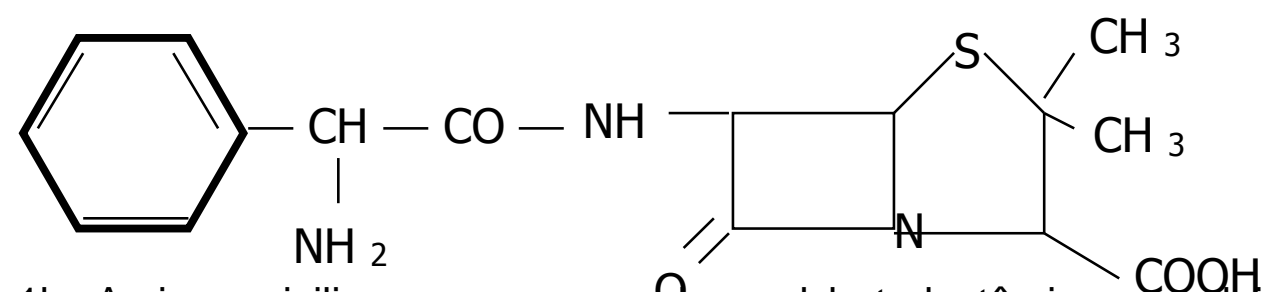

Figura 1b: Aminopenicilinas - presença Qo anel beta-lactâmico e cadelas laterais semelhantes

Ampicilina 
As penicilinas possuem um anel tiazolidina acoplado ao anel beta-lactâmico e uma cadeia lateral individual também ligada a ele pelo grupamento $\mathrm{NH}_{2}$ na posição $\mathrm{C}_{6}$. $\mathrm{O}$ anel beta-lactâmico se liga a grupamentos grupos de aminoácidos não nucleofílicos de proteínas levando à abertura deste anel e formação do grupo penicioloil, que compõe cerca de $90 \%$ dos grupos reativos entre proteínas. $O$ grupo peniciloil é o principal determinante antigênico responsável pela formação de anticorpos lgE específicos e também para a ativação de células T (Sachs, 2004; Weltzien, 1998). As penicilinas também podem formar outros determinantes antigênicos, os quais são produzidos em menor quantidade e, por isso, denominados de determinantes menores ou secundários. Precursores conhecidos dos determinantes menores incluem benzilpenicilina, seu produto de hidrólise alcalina (benzilpeniciloato) e seu produto de hidrólise ácida (benzilpeniloato), coletivamente chamado de mistura de determinantes menores. As reações anafiláticas a penicilina são geralmente mediadas por anticorpos da classe IgE contra os determinantes menores, por outro lado, algumas reações anafiláticas já foram descritas em pacientes com anticorpos lgE especificamente dirigidos contra o grupo peniciloil (Weltzien, 1998).

Durante muitos anos, achava-se que as cadeias específicas laterais possuíam menor importância na formação de epítopos para células T e B. Por isso, esperavam-se reações cruzadas entre todas as penicilinas, desta forma pacientes com história de alergia a penicilina eram rotulados como tal e orientados a evitar qualquer antibiótico deste grupo pela vida toda. Este 
tipo de abordagem levava a uma grande limitação na prescrição de antibioticoterapia e obrigava o uso de medicamentos com custo mais alto e que, muitas vezes, não condiziam com o padrão de sensibilidade bacteriana ideal descrita nos antibiogramas (Sachs, 2004).

As reações imediatas às penicilinas são, atualmente, muito bem estudadas. Entretanto, os mecanismos envolvidos no desenvolvimento do exantema maculo-papular e outras reações tardias mais graves, permanecem pouco compreendidos (Yawalkar, 2001a). Nos últimos anos, estudos desenvolvidos por diversos grupos utilizando métodos histopatológicos e imunohistológicos em biópsias cutâneas, além da análise de células $T$ específicas e clones de células $T$, mostraram que células $T$ droga-específicas desempenham um importante papel na patogênese do exantema induzido por medicamentos (Friedmann, 2003; Gerber, 2004; Gruchalla, 2001; Hertl, 1993a; Hertl, 1993b;Merk, 2002; Padovan, 1998; Pichler, 2003; Sachs, 2001a; Yawalkar, 2001a). 


\section{Objetivos:}

1. Estabelecer a freqüência de testes cutâneos positivos em pacientes com história de exantema maculo-papular e urticária tardia induzidos por antibióticos beta-lactâmicos;

2. Determinar a especificidade e sensibilidade dos métodos diagnósticos in vitro para reações tardias a medicamentos: linfoproliferação e dosagem de citocinas no sobrenadante de cultura de linfócitos. 


\section{Revisão da Literatura:}

\section{Classificações das reações a antibióticos $\beta$-lactâmicos:}

Em 1966, Levine e colaboradores propuseram uma classificação para as reações adversas a medicamentos baseada no tempo de início dos sintomas. Reações imediatas ocorrem dentro da primeira hora após a administração da droga e se manifestam clinicamente por urticária, rinite, chiado, dispnéia, edema laríngeo e de face, hipotensão e choque. As reações classificadas como aceleradas ocorrem 1 a 72 horas após a administração da droga e se manifestam, na maioria das vezes, com urticária, porém edema laríngeo é visto somente de forma ocasional. As reações tardias se iniciam mais de 72 horas após o início do tratamento com a droga e incluem: exantema máculo-papular, febre induzida por drogas, 
anemia hemolítica, nefrite, leucopenia, dermatite exfoliativa, síndrome de Stevens-Johnson e doença do soro. Esta última pode incluir febre, artralgia, adenopatia, lesões cutâneas e envolvimento renal.

Outra forma de classificar as reações imunológicas a medicamentos, baseia-se nos mecanismos imunopatológicos envolvidos, ou seja, a classificação dos tipos de hipersensibilidade proposta por Gell \& Coombs (Weiss, 1998).

\section{Tipo I: Hipersensibilidade Imediata}

Reações do tipo I resultam da síntese de lgE específica contra antígenos $\beta$-lactâmicos (determinantes maiores, menores ou cadeias laterais). A interação destes antígenos com a lgE específica ligada aos mastócitos ou basófilos via $\mathrm{F} c \varepsilon \mathrm{RI}$ (receptor de alta afinidade para $\lg \mathrm{E}$ ) leva à liberação de mediadores pré-formados ( histamina, triptase, etc) e neoformados (prostaglandinas, leucotrienos, PAF, etc) (von Greyerz, 1999). Estas reações geralmente ocorrem imediatamente, dentro de 20 a 30 minutos após a administração da droga e podem manifestar-se por urticária, edema laríngeo, broncoespasmo, hipotensão e colapso cardiovascular (Weiss, 1998).

Nos Estados Unidos da América, as penicilinas constituem a primeira causa de anafilaxia e são responsáveis por aproximadamente $75 \%$ dos 
episódios fatais a cada ano. Penicilina mostrou ser a causa de anafilaxia $0,002 \%$ da população geral ou 500 a 1000 mortes por ano dentre os usuários desta classe de drogas (Neugut, 2001). Os casos de anafilaxia não fatais induzidos por penicilina varia de 0,7 a $10 \%$ da população geral nos EUA (Neugut, 2001).

\section{Tipo II: Anticorpos Citotóxicos}

As reações citotóxicas podem ser graves. Elas ocorrem quando antígenos $\beta$-lactâmicos ligam-se à superfície das células sanguíneas ou do interstício renal. Anticorpos específicos das classes lgG e IgM interagem com estes antígenos, levando à ativação do sistema complemento e, consequentemente, lise celular. Este fenômeno ocorre mais frequentemente em pacientes com uso prolongado de penicilinas e antibióticos relacionados (Weiss, 1998). As manifestações clínicas incluem anemia hemolítica, trombocitopenia, granulocitopenia ou nefrite induzida por droga.

\section{Tipo III: Reações por Imunocomplexos}

Anticorpos $\beta$-lactâmico-específicos das classes lgG e IgM podem formar complexos circulantes com os antígenos $\beta$-lactâmicos. Estes imunocomplexos podem levam a fixação de complemento e se depositar em diversos tecidos, causando reações similares a doença do soro e, possivelmente, é um dos mecanismos envolvidos na febre induzida por drogas (Weiss, 1998). Clinicamente, apresenta-se com febre, erupções 
cutâneas, urticária, linfoadenopatia e artralgia que tipicamente surgem 1 a 3 semanas após a administração da última dose da droga.

\section{Tipo IV: Hipersensibilidade Mediada por Células}

São reações mediadas por linfócitos $\mathrm{T}$, os quais reconhecem antígenos $\beta$-lactâmicos e/ou porções da molécula carreadora através do receptor de células T (TCR), desencadeando a liberação de citocinas, recrutamento de outros tipos celulares e inflamação tecidual. Uma das apresentações clínicas mais clássicas é a dermatite de contato alérgica e, o grande número de casos de dermatite de contato com uso de penicilina tópica, levou a sua retirada do mercado (Weiss, 1998).

Este sistema de classificação das reações imunológicas a drogas tem sido útil na prática clínica diária e auxilia decisões diagnósticas. Entretanto, o termo "reações de hipersensibilidade tardia", originalmente utilizadas para descrever reações a tuberculina mediadas por células $\mathrm{T}$, mostrou-se como um leque variado de reações com participação de linfócitos $T$ com várias apresentações clínicas distintas (Pichler, 2003). Sabe-se que as células T são capazes de secretar diferentes padrões de citocinas resultando em diferentes doenças. Células T auxiliares tipo I (Th1) estimulam macrófagos a secretarem grandes quantidades de IFN- $\gamma$ com conseqüente produção de anticorpos fixadores de complemento, resposta pró-inflamatória (produção de TNF- $\alpha$, IL-12) e ativação da resposta citotóxica (células T CD8+). Enquanto isso, células T auxiliares do tipo II (Th2) secretam um padrão diferente de citocinas, com predomínio de IL-4 e IL-5. Estas citocinas 
estimulam a produção de $\lg E$ e $\lg G 4$ pelos linfócitos $B$, ativação de macrófagos, mastócitos e eosinófilos (Luque, 2001).

As células $T$ são capazes de reconhecer pequenos peptídios, mas também estão envolvidas na resposta imune a substâncias químicas pequenas. As descrições originais das reações imunes celulares são baseadas na resposta a haptenos, e muitas, como a dermatite de contato a pequenos químicos, já foi exaustivamente estudada. Entretanto, o mesmo não ocorre com as reações tardias a medicamentos, uma vez que sua apresentação clínica é muito heterogênea e não existem modelos animais estabelecidos para estudos.

Estudos recentes mostram o envolvimento de resposta de células $T$ em alguns casos de reações tardias a penicilina. Linfócitos de pacientes com estas reações proliferam in vitro após estimulação com o $\beta$-lactâmico responsável. Clones de linfócitos $T$ antígenos específicos provenientes destas culturas pertencem aos fenótipos CD4+ ou CD8+ e apresentam um padrão de citocinas heterogêneo após estimulação específica. Em estudos realizados em lesões cutâneas, o fenótipo de linfócito $T$ identificado foi principalmente CD8+ que expressa atividade citolítica contra os queratinócitos e celulas B autólogas (Padovan, 1998).

Histologicamente, biópsias de lesões de exantema maculo-papular mostram um infiltrado mononuclear superficial leve a moderado, principalmente perivascular, com eosinofilia. Estudos de imunofenotipagem do infiltrado celular mostram que este é composto em sua maioria por células T CD3+ com predominância de células CD4+, porém, algumas 
células CD8+ também estão presentes (Brander, 1995; Kuechler, 2004; Yawalkar, 2001b). Cerca de 20\% das células deste infiltrado expressam perforina e granzima B (Posadas, 2002; Yawalkar, 2000a), importante mediadores das reações celulares citotóxicas. Além deste comportamento citotóxico, as células T específicas liberam uma série de citocinas de padrão heterogêneo, incluindo citocinas de padrão Th1 e Th2. Existem relatos da ocorrência de expressão moderada de IFN- $\gamma$ e grandes quantidades de IL-5 (Brugnolo, 1999; Choquet-Kastylevsky, 1998; Gaspard, 2000; Halevy, 2005; Padovan, 1999; Posadas, 2000; Sachs, 2002; Yawalkar, 2000b). Outras citocinas têm sido implicadas no ambiente pró-inflamatório descrito durante estas reações, entre elas: IL-6, IL-1 $\alpha$ e TNF- $\alpha$ (Posadas, 2000; Yawalkar, 2000b).

Em 2003, Pichler, em um artigo de revisão sobre reações tardias a drogas, aplica pela primeira vez estes conceitos na classificação das reações alérgicas a drogas. Este autor subdivide as reações tardias mediadas por células em quatro subtipos: IVa, IVb, IVc e IVd (tabela 2)._O tipo IVa apresenta um mecanismo de resposta imune predominante Th1 com secreção de IFN-gama e ativação de monócitos, clinicamente representada pelos eczemas. O tipo IVb, possui uma ativação predominante Th2 e secreção de IL-4 e IL-5 com migração de eosinófilos para o sítio inflamatório; clinicamente começam a surgir o exantema máculo-paular e as lesões bolhosas. No tipo IVc, já ocorre uma ativação maior de células citotóxicas com expressão de granzima B e perforina. Estas, por sua vez, levam à lise da células alvo e surgimento de lesões cutâneas como o exantema máculo- 
papular, lesões bolhosas de maor gravidade. No tipo IVd, existe uma ativação maior de IL-8 com quimiotaxia de neutrófilos para o sítio inflamatório, originando a formação de pústulas estéreis na pustulose exantemática aguda generalizada.

Tabela 2: Relação entre apresentação clínica e tipos de hipersensibilidade

\begin{tabular}{|c|c|c|c|c|c|}
\hline $\begin{array}{l}\text { Gell \& } \\
\text { Coombs } \\
\text { Modificada }\end{array}$ & $\begin{array}{l}\text { Resposta } \\
\text { Imune }\end{array}$ & $\begin{array}{l}\text { Caract. } \\
\text { Patológica }\end{array}$ & $\begin{array}{l}\text { Quadro } \\
\text { Clínico }\end{array}$ & $\begin{array}{l}\text { Tipo de } \\
\text { Ligação }\end{array}$ & $\begin{array}{l}\text { Tipo } \\
\text { Celular }\end{array}$ \\
\hline Tipo I & $\lg \mathrm{E}$ & $\begin{array}{l}\text { Degranulação } \\
\text { mastócitos }\end{array}$ & $\begin{array}{l}\text { Urticária } \\
\text { Anafilaxia }\end{array}$ & Covalente & Cél. B / Ig \\
\hline Tipo II & $\overline{\lg G}$ & ADCC & $\begin{array}{l}\text { Discrasias } \\
\text { sanguíneas }\end{array}$ & Covalente & Cél. B / Ig \\
\hline Tipo III & $\begin{array}{l}\text { IgG } \\
\text { Complemento }\end{array}$ & Deposição IC & Vasculite & Covalente & Cél. B / Ig \\
\hline Tipo IVa & Th1 (IFN-Y) & $\begin{array}{l}\text { Ativação } \\
\text { Monócitos }\end{array}$ & Eczema & $\begin{array}{l}\text { Covalente e } \\
\text { não covalente }\end{array}$ & Céls. T \\
\hline Tipo IVb & $\begin{array}{l}\text { Th2 (IL-5 e } \\
\text { IL-4) }\end{array}$ & $\begin{array}{l}\text { Inflamação } \\
\text { eosinofílica }\end{array}$ & $\begin{array}{l}\text { Exantema MP } \\
\text { e bolhoso }\end{array}$ & $\begin{array}{l}\text { Covalente e } \\
\text { não covalente }\end{array}$ & Céls. T \\
\hline Tipo IVc & $\begin{array}{l}\text { CTL } \\
\text { (perforina e } \\
\text { granzima) }\end{array}$ & $\begin{array}{l}\text { Morte cel por } \\
\text { CD4 e CD8 }\end{array}$ & $\begin{array}{l}\text { Exantema } \\
\text { MP, bolhoso e } \\
\text { pustuloso }\end{array}$ & $\begin{array}{l}\text { Covalente e } \\
\text { não covalente }\end{array}$ & Céls. T \\
\hline Tipo IVd & Céls. T (IL-8) & $\begin{array}{l}\text { Ativação e } \\
\text { recrutamento } \\
\text { neutrófilos }\end{array}$ & $\begin{array}{l}\text { Pustulose } \\
\text { exantemática }\end{array}$ & $\begin{array}{l}\text { Covalente e } \\
\text { não covalente }\end{array}$ & Céls. T \\
\hline
\end{tabular}


CTL: células citotóxicas; IFN: interferon; Ig: imunoglobulina; IL: interleucina; Th: célula T helper (auxiliar); ADCC: citotoxicidade celular dependente de anticorpos Somente a reação predominante é demonstrada. No exantema máculo-papular, os tipos IVb e IVc podem ocorrer ao mesmo tempo; na pustulose exantemática, os tipos IVb, IVc, e IVd podem ocorrer de forma concomitante; no exantema bolhoso, os tipos IVc, IVb e IVa podem aparecer ao mesmo tempo. Na maioria dos casos, um subtipo predomina clinicamente.

\section{Imunopatologia das reações tardias a medicamentos:}

As características mais particulares das drogas, e que contrasta com a maioria dos outros antígenos, é que, com rara exceções ( como Lasparginase, insulina, soros heterólogos e fatores da coagulação ), elas são pequenas ( $<1000$ d ) e não protéicas. O sistema imune se desenvolveu para responder primeiramente e de forma mais eficiente à grandes partículas protéicas, que são metabolizadas em peptídios menores, os quais iniciam a resposta imune. A especificidade antigênica deriva do reconhecimento de um único epítopo pelo sistema imune, que por sua vez se liga a receptores tanto em linfócitos B (através de uma imunoglobulina de superficie) ou linfócito T (através de seu receptor - TCR). Em contraste, drogas são partículas muito pequenas para interagir diretamente, tanto à uma imunoglobulina de superficie como ao TCR, e, desta forma, devem ligar-se 
de forma covalente a substâncias carreadoras maiores, geralmente um peptídio, antes de se tornarem imunogênicas. Assim, as drogas não constituem por si só, um antígeno completo e são denominadas haptenos. A maioria das drogas não possui a capacidade de formar ligações covalentes com componentes tissulares e portanto, não são imunogênicas. Entretanto, algumas, como os antibióticos beta-lactâmicos, são altamente reativos e após sua introdução no organismo, rapidamente se ligam a proteínas autólogas. Em contrapartida, outras drogas não são intrinsicamente reativas com proteinas autólogas, mas precisam ser metabolizadas até uma forma que possa se ligar covalentemente ao carreador. Por exemplo: as sulfonamidas, fenitoína, carbamazepina, dapsona e rifampcina so metabolizadas pelo fígado via $\mathrm{N}$-acetilação ou $\mathrm{N}$-oxidação pelo citocromo P450 em suas formas imunologicamente ativas. Variações individuais nas vias de metabolização, como taxa de acetilação, pode contribuir para uma maior susceptibilidade em desenvolver alergia a droga e à predisposição familiar deste tipo de reação. Por exemplo, defeitos hereditários na enzima que metaboliza arilaminas pode ser responsável pela síndrome de hipersensibilidade a fenitoína. A influência de uma única característica individual no desenvolvimento deste tipo de reação é, de alguma forma, análoga àquela observada na atopia; o componente familiar envolve uma predisposição inespecífica no desenvolvimento $\lg \mathrm{E}$ especifica contra inalantes. No caso dos haptenos, o componente familiar pode envolver um padrão geneticamente determinado de metabolismo e processamento do antígeno. Isto poderia explicar a característica familiar das reações de 
hipersensibilidade a drogas, mas existem também caracteríscas individuais de exposição, genes da resposta imune e o papel ainda incerto das infecções (Borish, 1998).

Um dos desafios em estudar alergia a drogas é nossa limitação em determinar a forma haptenizada da droga. Apesar dos pontos de contato entre a forma antigênica completa do hapteno e a imunoglobulina de superficie ou TCR presumivelmente incluir a droga, estes domínios de ligação dos antígenos também incluem ligações não-covalentes com a molécula carreadora. Muitas novas descobertas vêm deste conceito. Primeiramente, tornou-se impossível estudar adequadamente a imunologia da alergia a droga sem ter disponível a forma imunogênica da mesma. Apesar de ser importante saber qual classe de linfócitos $T$ responde ao hapteno ( $\gamma \delta, C D 4+, C D 8+$ ou NK - natural killer), o fenótipo e o repertório de citocinas das células envolvidas na resposta (TH1ou TH2), e a localização tecidual das células $T$ responsivas, isto não é factível sem o conhecimento da proteína ou carreador ao qual a droga esta ligada, a fonte tecidual deste carreador, e a forma metabolizada e haptenizada da droga. Existe uma consequência adicional deste conceito de que a resposta imune a uma droga ou hapteno represente de fato uma interação entre o sistema imune e drogas ligadas covalentemente a uma proteína carreadora autóloga. Apesar deste conceito permitir o desenvolvimento de uma resposta imune específica IgE mediada, este processo pode também contribuir para muitos dos aspectos inflamatórios sistêmicos da alergia a drogas. Uma resposta citotóxica, celular ou humoral específica a uma droga ligada de forma 
covalente a um substrato tecidual, possui claramente o potencial de produzir dano a este tecido. Por exemplo, uma resposta imune dirigida contra uma droga ligada de forma covalente a pele ou eritrócitos pode levar a uma erupção cutanea induzida por droga ou anemia hemolítica, respectivamente. Por outro lado, como a proteína autóloga torna-se um dos componentes da forma imunogênica da droga, a resposta imune pode se desenvolver contra a proteína carreadora, ultrapassando os mecanismos internos de tolerância e levando ao desenvolvimento de doenças autoimunes (Borish, 1998).

\section{Processamento e Apresentação do Antígeno:}

Não importa qual forma antigênica funcional a droga "haptenizada" possa tomar, o processo suseqüente que leva ao desenvolvimento de uma resposta de hipersensibilidade deve envolver o processamento do antígeno e sua apresentação. Existem duas forma principais de processamento e apresentação. A primeira envolve o processamento de antígenos gerados internamente na célula, sua apresentação pelo MHC (complexo principal de histocompatibilidade) classe I e ativação de linfócitosT CD8+ citotóxicos. Por outro lado, antígenos externos, após serem processados, são apresentados por moléculas de MHC de classe II, resultando em ativação de linfócitosT CD4+ helper. A resposta imune a drogas haptenizadas e processadas imunologicamente desta maneira demonstraríam restrição ao MHC, um mecanismo que poderia contribuir para a propensão familiar da alergia a 
drogas. Da mesma forma, polimorfismos enzimáticos e de transportadores envolvidos no processamento e apresentação podem contribuir para esta susceptibilidade genética (Borish,1998).

Um terceiro mecanismo através do qual as drogas podem desencadear resposta imune é por interação direta de forma covalente as moléculas do MHC, pelo menos em alguns tipos de hipersensibilidade a beta-lactamicos, epítopos imunogênicos penicilina-específicos podem ser apresentados a clones de linfócitosT sem a necessidade de processamento do antígeno (Borish,1998).

O mecanismo interno de processamento antigênico foi primeiramente desenvolvido para permitir ao sistema imune combater infecções virais. Caracteristicamente, proteínas derivadas de vírus recém-sintetizados no retículo endoplasmático rugoso de células infectadas são ligadas de forma não covalente às também recém-sintetizadas moléculas de MHC de classe I. Este processo tem início através da clivagem proteolítica dos novos peptídios virais dentro dos proteossomos por um conjunto de enzimas polimórficas denominadas grandes partículas proteolíticas multicatalíticas (LMP). Estes proteossomos lisam o peptídio intacto em pequenos pedaços com 8 a 12 aminoácidos, que possuem o tamanho ideal para ligar-se às moléculas do MHC. No estágio subsequente, estes peptídios são transportados ativamente através do retículo endoplasmático por um complexo de transportadores inespecíficos denominados transportadores associados a apresentação antigênica (TAP-1 e TAP - 2). Assim como as enzimas LMP, as proteínas do TAP são polimórficas e codificadas dentro do 
complexo do MHC. Um vez dentro do retículo endoplasmático, o peptidio viral se liga de forma não covalente às moléculas recém-sintetizadas do MHC classe I. Este complexo então trafega até a superfície celular onde é reconhecido pelo linfócitoT CD8+ citotoxico, que destrói a célula infectada, prevenindo novas replicações virais. Uma vez que todas as células nucleadas expressam MHC I em sua superficie, este torna-se um mecanismo muito eficiente e virtualmente todas as células do organismo são capazes de se tornar imunologicamente ativas contra vírus (Borish,1998).

Algumas evidências físicas mostram que este tipo de mecanismo pode estar envolvido nas reaões de hipersensibilidade a drogas. Apesar de ser pouco provável que grandes proteínas extracelulares possam ser processadas dentro dos proteassomos e posteriormente transportadas pelas proteínas do TAP para dentro do retículo endoplasmático, isto pode não ser completamente verdade para as drogas. Muitas drogas são bases fracas que tipicamente possuem carga neutra em pH fisiológico e, desta forma, podem rapidamente se difundir através das membranas celulares e ter acesso a estruturas citoplasmáticas. As moléculas do TAP estão intimamente relacionadas ao transportadores resistentes a multidrogas (MDR), e compartilham a habilidade de transportar numerosos compostos complexos não relacionados através das membranas. Os transportadores TAP podem ser capazes de bombear drogas para dentro do retículo endoplasmático e permitir que estas sejam apresentadas pelo MHC I aos linfócitosT CD8+. É interessante especular que assim como somente os transportadores do MDR podem conferir resistência a numerosas drogas 
quimioterapicas, um processo semelhante envolvendo os transportadores TAP podem levar a uma tendência de desenvolver hipersensibilidade a numerosas drogas não relacionadas, o que é observado na síndrome de sensibilidade a múltiplas drogas. Polimorfismos tanto nas proteinas do TAP como nas enzimas LMP nos proteossomas, podem influenciar uma susceptibilidade individual de sensibilidade a droga e produzir uma predisposição familiar. Inicia-se assim, a reação tipo citotóxica mediada por linfócitosT CD8+ restritos ao MHC I (apesar de ser independente do processamento do antígeno) se a droga ou seu metabólito legarem-se diretamente a molecula do MHC expressa na superficie celular (Borish, 1998).

Apesar dos linfócitosT CD8+ citotóxicos ativados não produzirem reações alérgicas IgE-mediadas, este tipo de resposta pode ser relevante para uma das mais comuns formas de hipersensibilidade a droga. Existem relatos do sugimento de clones $\mathrm{CD} 8+$ restritos ao $\mathrm{MHC}$ I em indivíduos com sensibilidade a beta-lactâmicos, sulfametoxazol, fenitoína e carbamazepina. A hipótese destas células citotóxicas poderem contribuir para o desenvolvimento de reações cutâneas é reforçada pela demonstração de que linfócitosT CD8+ constituem o subtipo celular predominante em biópsias cutâneas de indivíduos com erupções vesico-bolhosas, necrólise epidérmica tóxica (NET) e exantema máculo-papular por beta-lactâmicos. Estes trabalhos demonstram clones de células $\mathrm{T}$ restritos ao $\mathrm{MHC}$ I penicilinaespecíficos. Fatores liberadores de histamina, como citocinas produzidas por estas células, podem produzir prurido e urticária geralmente associados a 
estes exantemas, e podem não requerer o desenvolvimento de IgE drogaespecífica (Borish,1998).

\section{Resposta T helper:}

A ligação do TCR com o complexo droga ou seu carreador e MHC II fornece o chamado primeiro sinal para ativação celular. Somente na presença do segundo sinal, o linfócito T é ativado e responde através de proliferação e produção de citocinas. O mais importante segundo sinal de ativação celular é a interação das moleculas B7 (B7.1 ou CD 80 e B7.2 ou CD86) expressas na superfície da célula apresentadora de antígenos (APC) com o CD28 expresso na membrana da célula T. Outros segundos sinais adicionais podem ser fornecidos pelo LFA-3 na APC com LFA-2 ou CD2 no linfócito T, ou mesmo por sinais secretórios (citocinas) como IL-1 ou IL-6. A ligação do TCR na ausência do segundo sinal, como em condições onde há excesso de antígeno, processamento inadequado ou apresentação do 
mesmo, não só impede a ativação da célula $\mathrm{T}$, como pode torná-la permanentemente irresponsiva ou tolerante, mesmo se, em exposições subsequentes, o antigeno for apresentado de forma correta. Este pode ser o mecanismo base da tolerância a alérgenos, como ocorre na indução de tolerância a drogas (desensibilização). Apesar deste ser um processo lento para explicar as desensilizações a drogas pela técnica de rush (rápidas), parece ser o mecanismo envolvido nas induções de tolerância lentas como com sulfametoxazol e fenitoína (Borish, 1998).

A ativação das células T esta associada a sua proliferação e secreção de citocinas. Proliferação linfocitária tem sido relatada com freqüência variável em associação com exposição a drogas e reações de hipersensibilidade, especialmente $\beta$-lactâmicos e sulfonamidas. O valor desta reação como método diagnóstico é prejudicada pela ausência de um antígeno completo relevante, isto é, "haptenizado", com o qual poderíamos realizar o teste; entretanto, quando positivo, ele provavelmente reflete o que ocorre in vivo. $\mathrm{O}$ repertório de citocinas produzidas por estas células T CD4+ restritas ao MHC II determina o tipo de resposta imune subseqüente. A produção de citocinas padrao TH1 incluindo TNF- $\alpha$ e IFN- $\gamma$, levam a ativação de macrófagos capazes de eliminar patógenos, células tumorais e outros alvos durante a resposta imune celular. Este tipo de resposta é responsavel pelas reações cutâneas de contato; entretanto, este mecanismo tambem pode contribuir para reações de hipersensibilidade pulmonares como no caso da nitrofurantoina e da nefrite intersticial induzida por drogas. Exantemas induzidos por drogas também podem ser decorrentes de uma resposta do 
tipo celular, já que podem estar associados a um teste de contato positivo com agente causal. Apesar do predomínio de células mononucleares neste tipo de reação sugerir uma resposta imune celular, na ausência de estudo especificos com imunofluorescência, o teste de contato não pode ser usado para distinguir uma resposta mediada por linfócitos T CD4+ de uma mediada po linfócitosT CD8+ citotóxicos.

Por outro lado, a produção de citocinas indutoras de resposta humoral, como IL-7, IL-10 1 IL-14, pode levar ao desenvolvimento de uma resposta mediada por anticorpos. Isto inclui a producao de $\lg G$ especifica e doenças mediadas por imunocomplexos como doença do soro ou danos diretos, como trambocitopenia e anemia hemolitica. Uma resposta imunológica não patogênica contra um medicamento pode ocorrer freqüentemente e pode ser evidenciada em indivíduos que apresentam transformação blástica de linfócitos frente a uma droga na ausência de reação de hipersensibilidade. Além disso, aproximadamente $40 \%$ dos pacientes que recebem mais que $2 \mathrm{~g}$ de penicilina por um período maior que 10 dias apresenta anticorpos IgG contra os determinantes antigênicos maiores da panicilina na ausência de reação de hipersensibilidade clinicamente evidente (Borish, 1998). 


\section{O Envolvimento das Celulas T:}

O envolvimento de anticorpos droga-específicos em algumas reações a medicamentos como anafilaxia, urticária, angioedema e anemia hemolítica já é bem conhecido. Por outro lado, o papel das células T droga-específicas ainda é controverso. Existem duas explicações possíveis: Pensava-se que as células T só poderiam reconhecer peptídios, e não haptenos ou drogas. De acordo com o modelo hapteno/carreador, os linfócitos $T$ são responsáveis pelo reconhecimento da molécula carreadora, mas são incapazaes de reconhecer os haptenos, ao contrário dos anticorpos (Di Piro, 1993); Apesar das amplas evidências de que infiltrados de células T estão presentes em várias reações alérgicas cutâneas, a função destas células T lesionais não eram bem compreendidas (Pichler, 2000). 
Entretanto, a experiência clínica em estudos laboratoriais indicam que as células T participam de várias reações alérgicas a drogas. Além disso, estudos recentes demonstram de forma convincente que substâncias não peptídicas naturais ou sintetizadas de baixo peso molecular, podem ser reconhecidas pelos linfócitos T. Tanto $\mathrm{LT} \alpha \beta$ como $\gamma \delta$ estão envolvidos no reconhecimento destes antígenos não peptídicos que são apresentados por moléculas do MHC ou MHC-like, como o CD1. Estes antígenos não peptídicos podem ser classifcados de acordo com sua estrutura em lipídios, prenil-pirofosfatos, açúcares, metais e drogas. Parece que o reconhecimento de alguns destes antígenos não peptídicos é importante para a resposta imune natural contra patógenos uma vez que, por exemplo, prenilpirofosfatos produzidos por micobactérias são reconhecidos por linfócitos T $\gamma \delta$ e podem desviar a resposta imune na direção do fenótipo Th1 (Pichler,2000).

Pichler, 2000, 2003 e 2004 vem estudando intensivamente o papel das células $\mathrm{T}$ nas alergias a drogas. Durante seus trabalhos este autor foi capaz de clonar células $\mathrm{T}$ específicas periféricas de pacientes alérgicos sensibilizados a penicilinas, cefalosporinas, sulfametoxazol, lidocaína e mepivacaína. Estes clones foram de grande valor para o estudo do mecanismo através do qual as células $T$ reconhecem as drogas e a função que estas desempenham in vivo. Outros achados também são relevantes:

1. Clones de células T droga-específicos são do tipo $\alpha \beta$ CD 4+ ou CD8+. Todos os clones são MHC restritos, porém 5 a 10\% deles são capazes de reconhecer drogas através de um mecanismo não restrito ao $\mathrm{MHC}, \mathrm{o}$ 
que pode contribuir para aumentar a capacidade de apresentação da droga.

2. Drogas quimicamente reativas como os antibioticos $\beta$-lactâmicos, podem modificar proteínas e peptídios diretamente de forma covalente e também modificar os peptídios ligados ao MHC. Esta alteração no hapteno pode gerar novos determinantes antigênicos e possibilita a imunogenicidade de um peptídio autólogo. A maioria das drogas é, entretanto, quimicamente inerte. Elas podem tornar-se imunogênicas através de seu metabolismo, uma vez que através dele podem ser gerados intermediários reativos que funcionem como haptenos. Por outro lado, drogas quimicamente inertes como lidocaína e sulfametoxazol, parecem não necessitar de processamento antes de se ligarem a proteínas ou peptídios, uma vez que APC fixas podem apresentar estas drogas, e que clones específicos começam a reagir quase imediatamente após o encontro da droga com a APC. Estudos concluiram que certas medicações possuem a propriedade de ligar-se diretamente, de forma não covalente, ao complexo MHC/peptidio/TCR. Esta ligação, apesar de fraca, é suficiente para estimular os clones de células T.

3. A maioria dos clones droga-específicos expressa fenotipo CD4+: grande parte deles secreta altos níveis de IL-5 e IL-4, mas alguns clones CD4+ e, particularmente, células T CD8+ possuem um padrão de citocinas Th1 bem definido (altas concentrações de IFN- $\gamma$, baixas níveis de IL-4 e IL-5). O aumento de IL-5 poderia explicar a eosinofilia freqüentemente presente 
tanto periférica como tecidual em pacientes alérgicos a determinadas drogas.

4. Muitos clones de células $T$ específicas são citotóxicos: não somente CD8+, mas também células CD4+ são capazes assumir este fenótipo citotóxico.

Estudos realizados com biópsias cutâneas de pacientes apresentando exantema do tipo máculo-papular generalizado induzido por drogas demonstrou que o infiltrado inflamatório cutâneo era composto predominantemente por células $\mathrm{T}$ ativadas. Este infiltrado apresentva células CD3+ ( 40 a 70\% ) com predominância de CD4+ (2/3) em relação às células tipo CD8+ ( $1 / 3)$. Cerca de $20 \%$ delas expressavam perforina e granzima $B$, tanto $C D 4+$ como $C D 8+$, fornecendo evidências do envolvimento de células CD4+ citotóxicas na patogênese das erupções a drogas in vivo. IFN- $\gamma$ foi detectado em linfócitos $\mathrm{T}$ do infiltrado, o que pode contribuir para o aumento da expressão de moléculas do MHC II nos queratinócitos. Em estudos imunohistoquímicos, estes queratinócitos mostraram-se positivos para HLA-DR e ICAM-1. A expressão destas moléculas poderia facilitar a ligação e ativação de células T citotóxicas, tornando-os mais susceptíveis à citotoxicidade mediada pelos linfócitos T. A IL-12 produzida por macrófagos e células dendríticas, é um potente fator estimulador e de maturação tanto para células T citotóxicas como para células NK, e um importante indutor da produção de IFN- $\gamma$. A presença desta interleucina em grande quantidade no infiltrado mononuclear no presente estudo 
pode representar um fator adicional responsável pela citotoxicidade mediada por células nas erupções cutâneas a drogas (Yawalkar,2000a).

\section{Fatores de risco associados às reações imunológicas a drogas:}

Já foram descritos alguns fatores de risco associados às reações imunológicas a drogas. A idade do pacientes é um destes fatores. Sabe-se que indivíduos entre 29 e 49 anos são mais susceptíveis a reações agudas a penicilina (Adkinson, 1984). Além disso, a responsividade imunológica e predisposição genética individual foram apontadas como fatores de risco importantes. Estudos desenvolvidos em animais e humanos indicam que a habilidade de um determinado indivíduo em responder imunologicamente a uma variedade de haptenos e polímeros de baixo peso molecular envolve uma predisposição genética (Adkinson, 1984). Adkinson e colaboradores, em 1984, demonstraram que somente metade dos adultos apresentam 
capacidade de desenvolver níveis detectáveis de IgG ou IgM em resposta à administração de penicilina.

Não há nenhuma evidência que sustente a hipótese de que atopia apresente algum papel na indução de uma resposta lgE-mediada específica a drogas. Por outro lado, uma história de atopia foi encontrada com maior frequência dentre indivíduos que sofreram episódios graves ou fatais de anafilaxia induzida por drogas. Uma constituição atópica relaciona-se a um maior risco de reações anafiláticas graves uma vez que a resposta mediada por IgE já foi desencadeada (Adkinson, 1984).

A administração parenteral de penicilina produz um maior número de reações alérgicas quando comparada à administração via oral. Entretanto, ainda não está totalmente esclarecido se este fenômeno está relacionado a menor dose que geralmente é administrada por esta última via, ou se está relacionada a variações destas diferentes vias em manejar e absorver os antígenos da penicilina.

As reações anafiláticas aos $\beta$-lactâmicos, assim como todas as reações imunologicamente mediadas, requerem uma exposição prévia para que exista sensibilização. Em casos raros, a sensibilização pode ocorrer durante a primeira exposição caso esta seja suficientemente longa. Além disso, raramente podem ocorrer exposições ambientais ocultas como no leite e na carne (von Greyerz,1999). 
IV. Justificativa:

Muito já se sabe sobre a fisiopatologia e diagnóstico das reações $\lg E$ mediadas por penicilinas, como descrito a seguir no item "Teste Cutâneos de Leitura Imediata". Os haptenos principais destas drogas já foram isolados e extratos para teste cutâneo de leitura imediata já foram padronizados em vários países. Por outro lado, poucas informações são disponíveis acerca das reações tardias como o exantema máculo-papular e urticária de início tardio relacionados aos antibióticos $\beta$-lactâmicos. Na última década, muitos investigadores encontraram evidências de que estas manifestações envolvem um mecanismo de hipersensibilidade tardia mediada por células ( 
tipo IV de Gell e Coombs ), e estão associadas a testes de contato e/ou teste cutâneo intradérmico de leitura tardia positivos (Romano,1999) Além disso, estudos realizados com biópsias cutâneas mostraram características histologicamente semelhantes à dermatite de contato e, em alguns casos, a provocação oral com a droga envolvida levou ao aparecimento de lesões cutâneas de início tardio (Romano,1999).

Em 1999, Romano e colaboradores mostraram que cerca de 50\% dos pacientes que apresentaram exantema máculo-papular durante tratamento com aminopenicilinas, apresentavam testes de hipersensibilidade tardia positivos com a droga responsável. Por outro lado, Primeau e colaboradores mostraram em 2002 que, em 16 pacientes com história de reação tardia a peniclinas, nenhum apresentou testes cutâneos intradérmico ou de contato positivos e realizados sob as mesmas condições dos estudos de Romano, porém em uma população diferente. Ambos os grupos são unânimes em salientar a importância da realização de novos estudos utilizando-se estes métodos diagnósticos.

Outro ponto importante a ser salientado é a freqüência de reações cruzadas entre os diversos antibióticos pertencentes a este grupo e que poderá ser, ao menos em parte, elucidado em nossa população.

O uso de antibióticos alternativos em pacientes com história de reação adversa prévia a penicilina é uma prática freqüente para a maior parte dos profissionais de saúde. Porém, muitas vezes, estas alternativas terapêuticas são mais caras, podem ser mais tóxicas do que os antibióticos $\beta$-lactâmicos, além do potencial em colaborar com a ocorrência de 
resistência bacteriana. Desta forma, a elucidação correta do diagnóstico da reação aos $\beta$-lactâmicos torna-se uma questão crucial sob todos esses aspectos.

\section{Métodos:}

1. Origem da população de estudo: Todos os indivíduos participantes de nosso estudo foram recrutados no ambulatório de Reações Adversas a Drogas do Serviço de Imunologia Clínica e Alergia do Hospital das Clínicas da Faculdade de Medicina da Universidade de São Paulo no período de janeiro de 2003 a janeiro de 2006. Foram estudados vinte pacientes com reações adversas a antibióticos betalactâmicos e quinze indivíduos controles. Todos assinaram o termo de consentimento pós informado. Este projeto foi aprovado pela comissão de ética para Análise de Projetos de Pesquisa - CAPPesq da Diretoria Clínica do Hospital das Clínicas e da Faculdade de 
Medicina da Universidade de São Paulo - Protocolo de Pesquisa número 934/02.

\section{Definições Operacionais:}

a) Reação Adversa a Droga: qualquer efeito colateral não intencional com um impacto negativo no indivíduo exposto.

b) Reação Imunológica a Droga: reação adversa a droga com característica, pela história, de uma síndrome lgE-dependente (anafilaxia, urticária), síndromes que envolvem anticorpos citotóxicos (citopenias, nefrite induzida por drogas), síndromes que envolvem imunocomplexos (febre, doença do soro-like, vasculites), ou síndromes com envolvimento de linfócitos $T$ (sensibilidade de contato, erupções cutâneas máculopapulares com ou sem prurido ou exfoliação, síndrome de Stevens-Johnson, necrólise epidérmica tóxica).

c) Reação alérgica ou imunológica de início tardio: baseada na classificação de Levine, 1966 são aquelas que se iniciam mais de 72 horas após a início do tratamento com a droga.

\section{Critérios de Inclusão:}

a) Idade $\geq 12$ anos

b) História de reação alérgica de início tardio a antibiótico $\beta$ lactâmico há menos de 1 ano. 


\section{Critérios de Exclusão:}

a) Presença de condição clínica associada a função imunológica anormal (Síndrome da imunodeficiência adquirida, imunodeficiência comum variável).

b) Necessidade de terapia imunossupressora contínua (prednisona $\geq 30 \mathrm{mg} / \mathrm{dia}$ nos últimos 15 dias, ciclosporina, quimioterapia nos últimos 2 anos, imuran, citoxan).

c) Comprometimento da memória ou habilidade de compreensão do termo de consentimento (analfabetismo, demência, retardo mental ou qualquer comprometimento do nível de consciência).

d) Pacientes com história de dermatite exfoliativa, Síndrome de Stevens-Johnson e Necrólise Epidérmica Tóxica.

e) Pacientes em uso de drogas $\beta$-bloqueadoras.

f) Pacientes com história de reações imediatas com as drogas estudadas.

g) Gravidez.

\section{Identificação dos Pacientes e Recrutamento:}

Pacientes em potencial foram entrevistados utilizando o questionário já validado no Johns Hopkins Asthma and Allergy Center em Baltimore, USA (Anexo 2) destinado ao diagnóstico de reações imunológicas a medicamentos.

Controles foram indivíduos maiores que 12 anos, com exposição prévia a antibióticos $\beta$-lactâmicos, porém sem história de reações. 
Os prontuários dos pacientes foram consultados quando o entrevistador apresentou dificuldades na classificação dos casos.

\section{Estudos Imunológicos:}

Os estudos imunológicos foram realizados nos indivíduos classificados como caso e nos controles. Os seguintes estudos imunológicos foram efetuados:

a) Teste de hipersensibilidade imediata:

\section{Reagentes:}

- BPO-PPL: benzilpeniciloil-polilisina Merck - Espanha

- MDM: mistura de determinantes menores Merck - Espanha

- Amoxicilina $1 \mathrm{mg} / \mathrm{ml}$ e $20 \mathrm{mg} / \mathrm{ml}$ :

- Ampicilina $1 \mathrm{mg} / \mathrm{ml}$ e $20 \mathrm{mg} / \mathrm{ml}$ :

- Histamina $1 \mathrm{mg} / \mathrm{ml}$ e Solução salina 0,9\%: IPI ASAC

Os testes cutâneos de hipersensibilidade imediata foram realizados em todos os pacientes com história de reação alérgica de início tardio a antibióticos $\beta$-lactâmicos, e nos indivíduos controles.

- Peniclina: Os reagentes utilizados foram PPL (peniciloil polilisina) e MDM (mistura de determinantes menores), ambos disponíveis comercialmente. $\mathrm{O}$ teste cutâneo de leitura imediata a penicilina é considerado um procedimento seguro quando realizado por pessoal treinado e com a técnica correta. Estavam disponíveis durante a realização de todos os testes, equipamento e medicações de emergência para tratar anafilaxia. Os testes 
cutâneos foram realizados em duplicata, com controles positivo (histamina $10 \mathrm{mg} / \mathrm{ml}$ ) e negativo (solução salina $0,9 \%$ ).

Técnica: Após assepsia da face volar do antebraço foram realizados os testes cutâneos por punctura. Em não ocorrendo formação de pápula no local ou sintomas sistêmicos depois de 15 minutos, era realizada injeção intradérmica com os mesmos reagentes conforme descrito adiante.

Anti-histamínicos, antidepressivos tricíclicos e drogas adrenérgicas foram suspensos por um período de 5 a 30 dias antes do procedimento, dependendo do medicamento em questão.

Riscos do procedimento: A frequência de reações sistêmicas durante os testes cutâneos de leitura imediata com regentes de penicilina está entre 0,12 a $1,2 \%$ dos pacientes com história positiva de reação a imediata a penicilina e 2,3 a $9,4 \%$ dos indivíduos com teste positivo (Schnyder, 2000). Geralmente estas reações são leves e resolvem totalmente com tratamento. Casos fatais são raros, porém episódios de anafilaxia foram relatados na literatura mundial, geralmente relacionados a falhas técnicas como administração de doses maiores do que as previstas inicialmente ou aplicação intradérmica não precedida de punctura (Sogn, 1992; Voorhost, 1980).

Não existem evidências que os reagentes utilizados durante o teste cutâneo possam sensibilizar os pacientes (Voorhost, 1980). A administração de penicilina a indivíduos com teste cutâneo negativo, leva a reações agudas em 0,5\% daqueles com história negativa de reação e 2,9\% 
daqueles com história positiva de reações prévias a penicilina. Estes casos são geralmente leves e auto-limitados (Sogn, 1982).

- Amoxicilina a Ampicilina: Ambas as drogas foram testadas utilizandose a mesma técnica acima descrita para penicilina na concentração de 2 mg/ml como previamente descrito por Romano e colaboradores em 2004.

b) Pesquisa in vitro de IgE específica a penicilina, amoxacilina e ampicilina (Blanca, 2001):

A determinação de lgE sérica específica foi realizada através do método UniCAP ${ }^{\circledR} 100$ baseado na tecnologia ImmunoCAP ${ }^{\circledR}$ e utiliza o mesmo ensaio fluoenzimático (FEIA), Pharmacia CAO System, Suécia. A fase sólida consiste em um recipiente revestido com cadeias de polímeros hidrofóbicos flexíveis. O carreador é um derivado de celulose ativada com $\mathrm{CNBr}$ (brometo de cianogênio). O sistema usa combinações de anticorpos IgE específica e anticorpos monoclonais conjugados a beta-galactosidase e gerando fluorescência através da quebra do substrato fluorescente 4metillumbelliferil-beta-D-galactoside em 4-metillumbelliferon. $\mathrm{O}$ experimento é calibrado pelos padrões de referência da Organização Mundial de Saúde e inclui 2 conjuntos de calibradores.

Os antígenos utilizados foram: penicilina G (c1), ampiciloil (c5) e amoxaciloil (c6) do mesmo fornecedor (Pharmacia®, Suécia).

Os resultados da detecção de IgE específica serão expressos segundo a tabela abaixo:

Tabela 3: Resultados da detecção de IgE sérica específica

\begin{tabular}{|l|l|l|}
\hline $\begin{array}{l}\text { Resultado } \\
\text { quantitativo }\end{array}$ & $\begin{array}{l}\text { Níveis do anticorpo } \\
\text { alérgeno-específico }\end{array}$ & $\begin{array}{l}\text { Resultado- } \\
\text { semiquantitativo }\end{array}$ \\
\hline
\end{tabular}




\begin{tabular}{|l|l|l|}
\hline$\left(\boldsymbol{k U} \mathbf{I}_{\boldsymbol{A}} / \mathbf{l}\right)$ & & $\begin{array}{l}\text { (Classe de } \mathbf{l g} \boldsymbol{E} \\
\text { específica) }\end{array}$ \\
\hline$<0,35$ & Ausente ou indetectável & 0 \\
\hline $0,35 \mathrm{a}<0,7$ & Baixo & 1 \\
\hline $0,7 \mathrm{a}<3,5$ & Moderado & 2 \\
\hline $3,5 \mathrm{a}<17,5$ & Alto & 3 \\
\hline $17,5 \mathrm{a}<50$ & Muito alto & 4 \\
\hline $50 \mathrm{a}<100$ & Muito alto & 5 \\
\hline 100 ou mais & Muito alto & 6 \\
\hline
\end{tabular}

Os valores de lgE sérica específica são expressos em kUA/l onde $A$ representa anticorpos alérgeno específicos. Valores de $0,35 \mathrm{kUA} / \mathrm{l}$ ou mais representam um aumento progressivo na concentração de anticorpos alérgeno-específicos. Resultados inferiores a $0.35 \mathrm{kUA} / \mathrm{l}$ indicam ausência ou níveis indetectáveis de anticorpos específicos.

\section{c) Testes de hipersensibilidade tardia: teste de contato e intradérmico:}

Os testes de contato de hipersensibilidade tardia e teste intradérmico foram baseados na técnica descrita por Romano e colaboradores, 2004.Os testes intradérmicos foram aplicados na face volar do antebraço usando seringa e agulha de insulina; um volume de $0,02 \mathrm{ml}$ dos seguintes reagentes: peniciloil-polilisina com concentração plena ( $\left.6 \begin{array}{llll}6 & 10 & -5 & \mathrm{mEq}\end{array}\right)$, mistura de determinantes menores (10 $\mathrm{mM}$ de benzilpenicilina, benzilpeniciloato e benzilpeniloato), amoxacilina $(2 \mathrm{mg} / \mathrm{ml})$, ampicilina $(2 \mathrm{mg} / \mathrm{ml})$ e diluente (solução fisiológica $0,9 \%$ ). Todos os reagentes foram preparados em solução salina tampão, em pH de 7,4 e diluídos em diluentes regulares para extratos alergênicos, o teste intradérmico foi sempre precedido por punctura. O local de realização do teste foi examinado após 20 minutos para resposta imediata e qualquer sinal de reação local foi marcado e anotado. O sítio de 
cada aplicação foi marcado com caneta indelével e novamente avaliado após 48 horas. Um teste intradérmico foi considerado positivo quando da presença de pápula maior que $5 \mathrm{~mm}$ quando comparada ao controle diluente (Torres,2001).

O teste de contato foi realizado utilizando os seguintes reagentes: benzilpenicilina (5.000 Ul/grama de vaselina sólida), ampicilina (5\% em vaselina sólida), amoxacilina ( $5 \%$ em vaselina sólida) e controle (vaselina pura) conforme descrito por Romano e colaboradores (2004). Os reagentes foram armazenados a $-20^{\circ} \mathrm{C}$ e aplicados em duplicata utilizando o sistema Finn Chamber on Scampor (FDA Allergic, Brasil). Os testes de contato foram avaliados após 48 e 72 horas de acordo com os critérios do Grupo Internacional de Dermatites de Contato (Adams, 1981). O teste de contato também foi realizado em duplicata.

\section{d) Proliferação Linfocitária:}

\section{Material Utilizado:}

- Luvas de látex estéreis

- Tubos Falcon de $50 \mathrm{ml}$

- Tubos de $12 \mathrm{ml}$

- Pipetas sorológicas

- Pipetas de Pasteur

- Pipetas Gilson

- Ponteiras 
- Solução salina

- Meio RPMI 1640

- Ficoll-Hypaque (d=1,076 g/ml)

\section{Procedimentos Técnicos:}

1. Obtenção das amostras de sangue:

Amostras de sangue venoso periférico foram coletadas dos indivíduos que apresentarem testes cutâneos positivos. Foram utilizadas luvas de látex não estéreis e tubos de coleta a vácuo contendo heparina sódica: agulha número $20(3,8 \mathrm{~cm})$ (Vacutainer, Becton-Dickinson) e um suporte de agulha descartável. As agulhas e suportes não eram re-utilizados, e ambos foram descartados em caixas especiais para materiais pérfuro-cortantes perigosos. Preferencialmente, as amostras eram coletadas pela manhã (entre $8 \mathrm{~h}$ e 10h).

Foram coletados $60 \mathrm{ml}$ de sangue heparinizado e $10 \mathrm{ml}$ de sangue em tubo seco.

2. Tempo e condições de armazenamento:

Amostras de sangue total foram mantidas a temperatura ambiente até o momento da análise realizada dentro de no máximo 8 horas após a coleta. Os resultados foram comparados com controles normais cujas amostras foram coletadas e tratadas de forma semelhante.

3. Retirada e processamento do soro: 
O tubo seco foi deixado à temperatura ambiente para retração do coágulo por aproximadamente 30 minutos e posteriormente centrifugado por 10 minutos a 2000 rpm. Foi retirado o soro livre de hemácias e inativado em banho-maria a $56^{\circ}$.C por 30 minutos.

4. Separação de mononucleares:

O sangue heparinizado foi diluído v/v em solução salina estéril 0,9\% e foram adicionados $10 \mathrm{ml}$ desta solução sobre um volume de $3 \mathrm{ml}$ de FicollHypaque. Posteriormente, centrifugado por 25 minutos a $1800 \mathrm{rpm}$. Foi retirada a nuvem de mononucleares localizada entre a interface do FicollHypaque e a solução salina.Esta nuvem foi coletada com o auxílio da pipeta de Pasteur e recolhida em um tubo de $50 \mathrm{ml}$ (Falcon).Foi adicionada solução salina até completar o volume final de $50 \mathrm{ml}$ do tubo e este foi centrifugado durante 10 minutos a $2000 \mathrm{rpm}$.

Após a centrifigação, o sobrenadante foi aspirado e o botão celular ressuspenso em $2 \mathrm{ml}$ de RPMl passando para um tudo de $15 \mathrm{ml}$. O tubo Falcon foi lavado com $2 \mathrm{ml}$ de meio por mais duas vezes e colocado no tubo de $15 \mathrm{ml}$. Após completar este último tubo para um volume final de $6 \mathrm{ml}$, foi centrifugado durante 8 minutos a $1800 \mathrm{rpm}$. O sobrenadante foi aspirado, as células ressuspensas em $3 \mathrm{ml}$ de meio e posteriormente contadas na câmara de Neubawer. Acertar a concentração das células para $2 \times 10^{6}$ com RPMl e soro inativado de modo que no volume final contenha $20 \%$ de soro. O total de células necessárias para todos os experimentos (proliferação e coleta do sobrenadante de cultura para dosagem de citocinas) foi de $55,5 \times 10^{6}$. 
5. Concentrações dos antígenos/mitógenos:

Geralmente, mitógenos como PHA foram incubados com as células por 72 horas. As drogas usadas como antígenos foram obtidas dos fabricantes: Penicilina G (5.000.000 UI - Tafarma - Brasil - lote 35FB05)), amoxicilina (SP Farma - lote 19256) e ampicilina (Strides Arcolab - Índia lote PLL4002) e utilizadas em concentrações que variaram entre 125 e 1000 $\mu \mathrm{l} / \mathrm{ml}(125,250,500$ e $1000 \mu \mathrm{l} / \mathrm{ml})$ (Nyfeler,1997; Pichler,2004).

Cada um dos medicamentos foi colocado em um tubo de Eppendorf. Os tubos vazios foram identificados e pesados vazios. Posteriormente, as drogas foram adicionadas dentro do fluxo laminar e os tubos, novamente pesados. Após subtração do peso do tubo cheio do peso do tubo vazio, obtivemos a quantidade de droga presente em cada um deles. Cada uma delas foi diluída em meio RPMI 1640 na concentração de $1 \mathrm{mg} / \mathrm{ml}$.

6. Montagem do experimento:

As placas de cultura de 96 poços com fundo em "U" (Becton Dickson, Lincoln Park, $\mathrm{NJ}$ ) foram envoltas em filme plástico e incubadas a $37^{\circ} \mathrm{C}$ em estufa com atmosfera umidificada a 95\% com $5 \%$ de CO2.

7. Distribuição na placa:

Todos os testes foram analisados em triplicata.

O controle não estimulado era composto por $100 \mu \mathrm{l}$ de células $\left(2 \times 10^{6}\right)$ $+100 \mu \mathrm{l}$ de RPMI, enquanto o controle estimulado era constiruído por $100 \mu \mathrm{l}$ 
de células $\left(2 \times 10^{6}\right)+100 \mu l$ de antígeno diluído na concentração determinada pela titulação.

8. Coleta e contagem celular:

Na manha do último dia de incubação das placas em atmosfera umidificada com $5 \%$ de $\mathrm{CO}_{2}$ e a $37^{\circ}$. C, as células foram pulsadas com 0,5 $\mu \mathrm{Ci} /$ poço de timidina triciada (Amersham Life Sciences). Após 6 horas, as células foram recolhidas em coletor específico (Cell-Harvest - Pharmacia) e a contagem da incorporação da timidina foi realizada através do método de cintilação líquida para radiação $\beta$, no contador Beta-Plate (WallacPharmacia, Suécia).

9. Cálculos:

O índice de estimulação foi calculado pela média das triplicatas para cada um dos antígenos, em com (contagem por minuto), dividido pela média da triplicata do controle negativo. Foram considerados positivos, valores de I.E. (índice de estimulação) acima de 3,0. 
As figuras $2^{\mathrm{a}}$ e $2 \mathrm{~b}$ mostram o aspecto da placa da cultura linfocitária: 


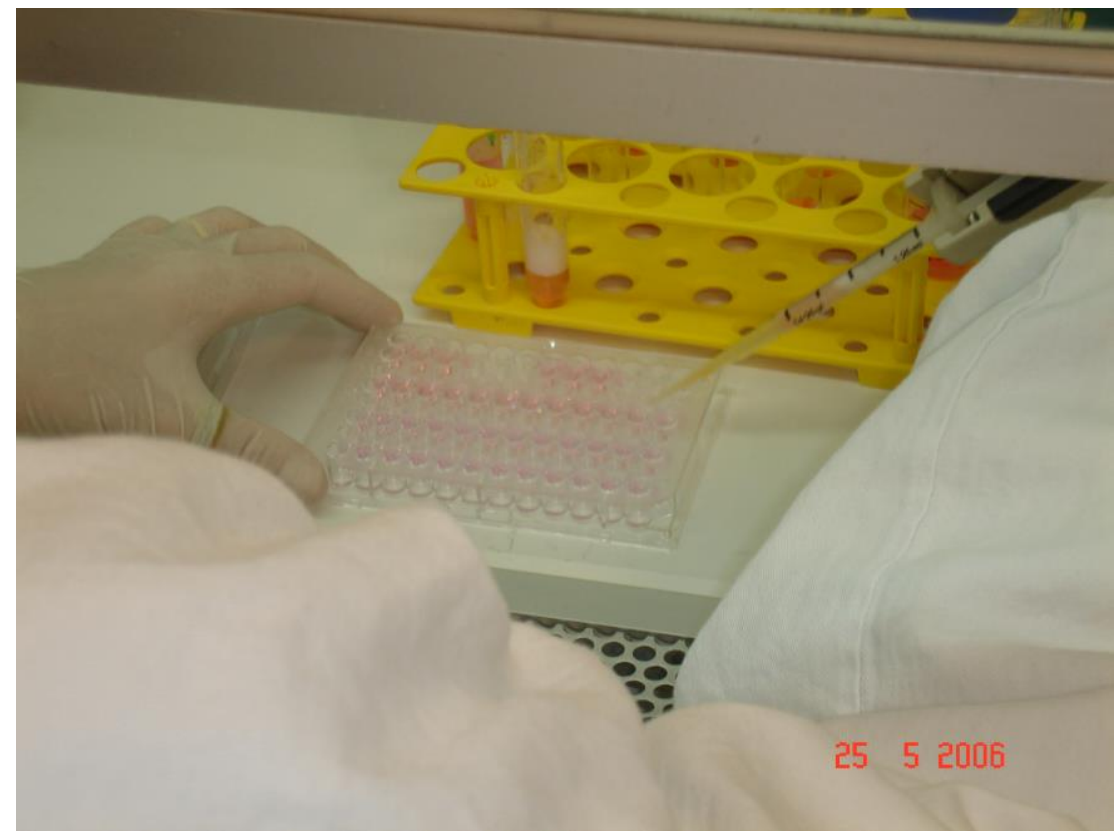

Figura 2 a: montagem da placa para cultura linfocitária

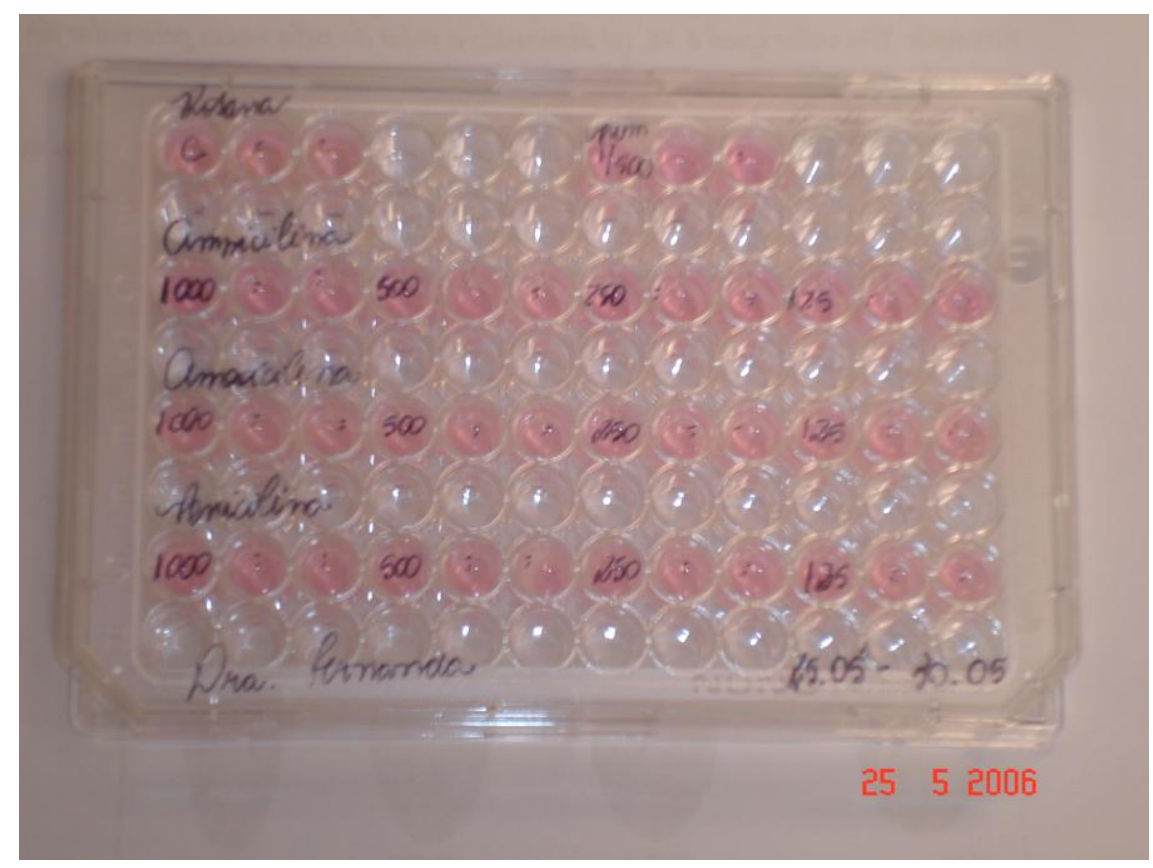

Figura 2b: Aspecto final da placa de cultura linfocitária

e) Dosagem de citocinas: 
Foram dosados os níveis de IL-5, TNF- $\alpha$ e IFN- $\gamma$ no sobrenadante da cultura tecidual utilizando-se ELISA.

\section{Material:}

- Placa de 48 poços de fundo chato

- Anticorpos de captura e detecção para IL-5, TNF- $\alpha$ e IFN- $\gamma$

- Solução Substrato ABTS (Sigma $\left.{ }^{\circledR}\right)$

- Solução de ligação: NaHPO4 0,1 M pH ajustado para 9,0 com NaH2PO4 $0,1 \mathrm{M}$

- Solução PBS: NaCl 80g, Na2HPO4 11,6g, KH2PO4 2g, KCl 2g qs para 10 $\mathrm{L} ; \mathrm{pH} 7,0$

- PBS/Tween®: 0,5 ml de Tween®-20 em 1 L PBS

- Solução tampão bloqueadora: soro bovino fetal 10\% (FBS) ou BSA $1 \%$ em PBS filtrada antes do uso.

- Solução tampão bloqueadora/Tween®: Adicionar 0,5ml de Tween-20® em $1 \mathrm{~L}$ de solução tampão bloqueadora.

- Solução H2O2 3\%

\section{Protocolo de ELISA para procedimentos gerais:}

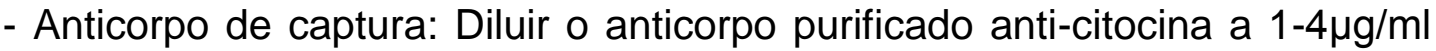
em solução ligante. Adicionar $100 \mu \mathrm{l}$ de anticorpos diluídos aos poços da placa. Selar a mesma para evitar evaporação e incubar durante a noite a $4 \stackrel{0}{ } \cdot$.

- Bloqueio: Remover a solução de anticorpo de captura e bloquear as ligações não específicas através da adição de $200 \mu \mathrm{l}$ de solução 
bloqueadora em cada poço. Selar a placa e incubá-la por 1 a 2 horas. Lavar 3 vezes com PBS/Tween®.

- Controles e amostras: Adicionar $100 \mu \mathrm{l}$ dos controles e amostras diluídas em solução bloqueadora/Tween®. Selar a placa e incubar por 2 a 4 horas ou durante a noite a $4^{\circ}$.C. Lavar 4 vezes em PBS/Tween ${ }^{\circledR}$

- Detecção do anticorpo: Diluir o anticorpo anti-citocina em 0,5 a $2 \mu \mathrm{l} . \mathrm{mg}$ de solução bloqueadora/Tween $\circledast$. Adicionar $100 \mu \mathrm{l}$ do anti-soro diluído a cada poço, selar a placa e incubá-la por 1 hora em temperatura ambiente. Lavar 4 vezes em PBS/Tween®.

- AV-HRP: Diluir o conjugado AV-HRP ou outro conjugado enzimático para sua concentração ideal em solução bloqueadora/Tween ${ }^{\circledR}$ e adicionar $100 \mu \mathrm{l}$ em cada poço. Selar a placa e incubá-la em temperatura ambiente por 30 minutos. Lavar 5 vezes em PBS/Tween ${ }^{\circledR}$.

- Substrato: Adicionar $100 \mu \mathrm{l}$ de $\mathrm{H} 2 \mathrm{O} 23 \%$ em $11 \mathrm{ml}$ de substrato. Colocar imediatamente $100 \mu \mathrm{l}$ em cada poço. Incubar em temperatura ambiente por 5 a 80 minutos para revelação da cor. Realizar a leitura por densidade óptica para cada placa com leitor de microplaca ajustado para $405 \mathrm{~nm}$.

As figuras monstram um exemplo do aspecto final das placas para dosagem de citocinas no sobrenadante da cultura linfocitária: 


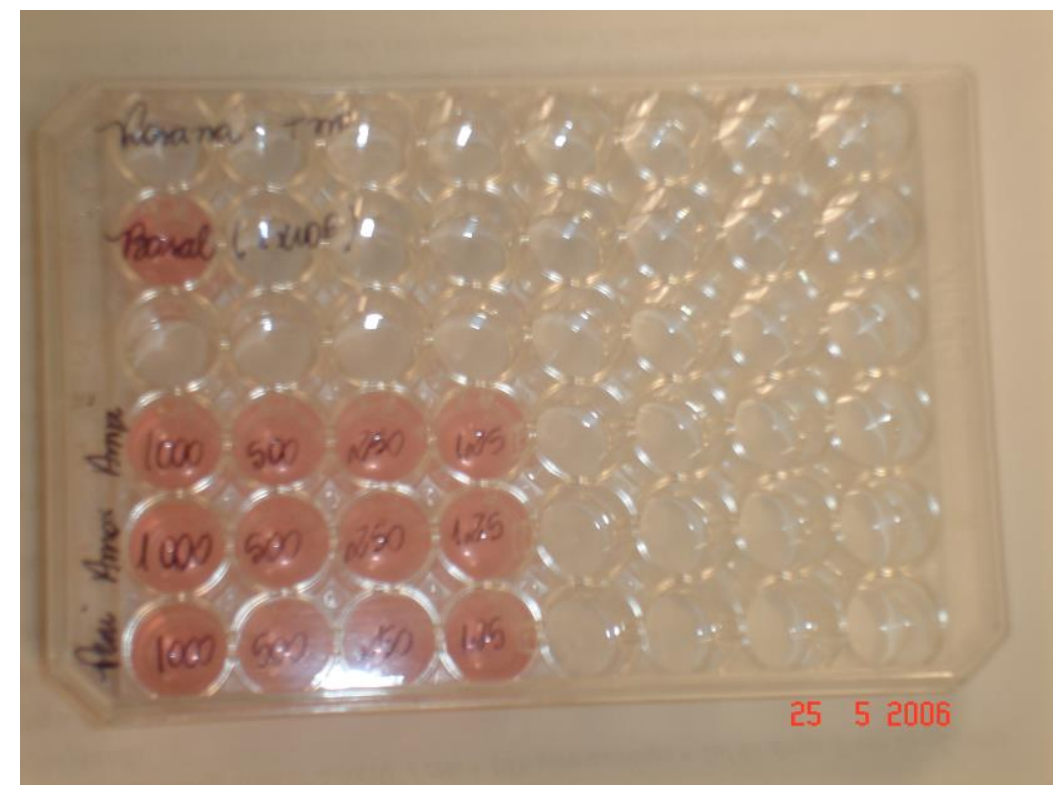

Figura 3a: Aspecto final da placa para dosagem de TNF-alfa no sobrenadante da cultura linfocitária

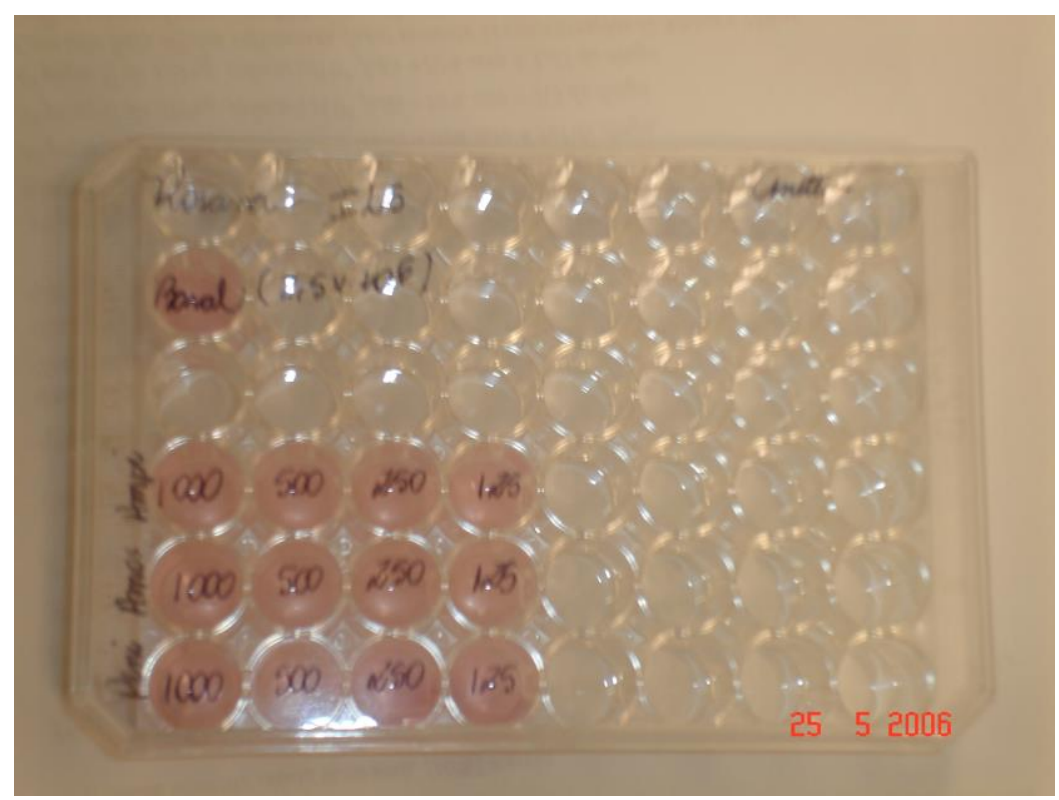

Figura 3b: Aspecto final da placa para dosagem de IL-5 no sobrenadante da cultura linfocitária 


\section{Análise Estatística:}

Os testes estatísticos e análises descritivas utilizados nessas análises foram obtidos através do programa estatístico SPSS 12.0 (Statistical Package for Social Sciences). Já os gráficos foram feitos no Excel.

Método: Teste Qui-Quadrado e Teste exato de Fisher

O teste utilizado na análise dos dados demográficos foi o teste estatístico Qui-Quadrado. Este teste serve para testar a hipótese de que duas variáveis categorizadas são independentes. 


\section{Resultados:}

\section{Características demográficas:}

A análise estatística foi realizada com 20 pacientes (14 mulheres e 6 homens) e 15 controles (4 homens e 11 mulheres). A média de idade foi de 38,05 anos no grupo de pacientes e de 30,46 no grupo controle. A média de tempo transcorrido entre a reação aguda e realização da investigação imunológica foi de 5 meses e 12 dias nos pacientes estudados. Quarenta e cinco porcentos destes indivíduos estavam em uso contínuo de alguma medicação como anticoncepcionais orais, inibidores de bomba de prótons e inibidores da enzima de conversão da angiotensina. O mesmo número de pacientes referiram história familiar de reações adversas a medicamentos, mas em somente um deles, a reação foi relacionada a um antibiótico do grupo dos beta-lactâmicos. Nove pacientes (45\%) apresentavam história pessoal de reação adversa a drogas: 4 deles com uma ou mais dos seguintes antibióticos: sulfametoxazol, ciprofloxacina e beta-lactâmico, os

outros 5 indivíduos com uso de antiinflamatórios não hormonais. Sessenta porcento dos pacientes eram atópicos (teste de puntura positivo para os seguintes aeroalérgenos: D. pteronissinus, Blomia tropicalis, epitélio de cão e epitélio de gato).

As características populacionais entre pacientes e controles, não houve diferença estatisticamente significante, exceto a média de idade, superior nos pacientes quando comparada com os indivíduos controle (teste exato de Fisher foi utilizado para análise destas variáveis - tabela 4). 
Tabela 4: Características populacionais baseadas nas respostas obtidas pela aplicação do questinário do JHAAC

\begin{tabular}{|l|l|l|}
\hline Característica & Pacientes & Controles \\
\hline Gênero & 6 homens/14 mulheres & 4 homens/11 mulheres \\
\hline Média de idade (anos) & $38,05- \pm 14,96$ & $30,46 \pm 7,04$ \\
\hline $\begin{array}{l}\text { Uso contínuo de } \\
\text { medicações\# }\end{array}$ & $45 \%$ & $53,3 \%$ \\
\hline $\begin{array}{l}\text { História pessoal de RAD } \\
\text { \#\# }\end{array}$ & $45 \%$ & $40 \%$ \\
\hline $\begin{array}{l}\text { História pessoal de } \\
\text { atopia }\end{array}$ & $60 \%$ & $60 \%$ \\
\hline $\begin{array}{l}\text { História familiar de RAD } \\
\text { Uso de mais que 3 } \\
\text { cursos de antibióticos } \\
\text { nos últimos 5 anos\#\#\# }\end{array}$ & $20 \%$ & $40 \%$ \\
\hline $\begin{array}{l}\text { Última exposição a } \\
\text { antibiótico beta- } \\
\text { lactâmico (meses) }\end{array}$ & $5,41 \pm 3,41$ & $>12$ \\
\hline
\end{tabular}

\# Uso contínuo de medicações: uso contínuo de um medicamento por período igual ou superior a 1 ano

\#\# RAD: Reação adversa a droga

\#\#\# Uso de mais que 3 cursos de antibióticos (período igual ou superior a 7 dias) nos últimos 5 anos

Resultados obtidos através da aplicação de questionário aplicado pelo próprio pesquisador na primeira visita após assinatura do termo de consentimento pósinformado.

Amoxicilina estava envolvida em $100 \%$ das reações. Somente 1 paciente havia feito uso de benzilpenicilina injetável 1 dia antes do início do uso da amoxicilina. Quinze pacientes (75\%) apresentavam história de 
exantema máculo-papular com uso do antibiótico envolvido, 3 indivíduos apresentaram urticária tardia (15\%). Outras reações encontradas foram o exantema morbiliforme e o eritema nodoso.

\section{Testes cutâneos de leitura imediata:}

Nenhum paciente ou controle apresentou teste cutâneo de leitura imediata positivo.

\section{Testes cutâneos de leitura tardia: intradérmico e de contato:}

Somente três pacientes apresentaram testes cutâneos de leitura tardia positivos nas leitura de 48 e 72 horas com amoxicilina $2 \mathrm{mg} / \mathrm{ml}$, Ampicilina 2mg/ml e penicilina G $10.000 \mathrm{Ul} / \mathrm{ml}$ (figura 4a, 4b e 4c) e teste de contato positivo com os mesmos reagentes (figura $5 a$ e $5 b$ ). Nenhum deles apresentou reação tardia positiva com PPL e MDM. Não houve resultados positivos dos testes cutâneos de leitura tardia (teste intradérmico e teste de conatato) no grupo controle. 


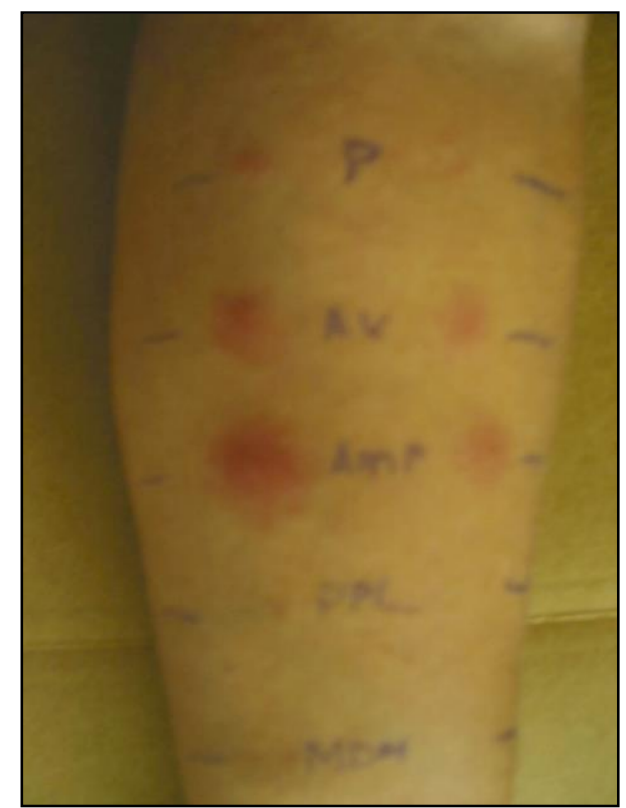

Figura 4a : Paciente APG - leitura de 48h teste cutâneo intradérmico positivo para ampicilina, amoxicilina e penicilina

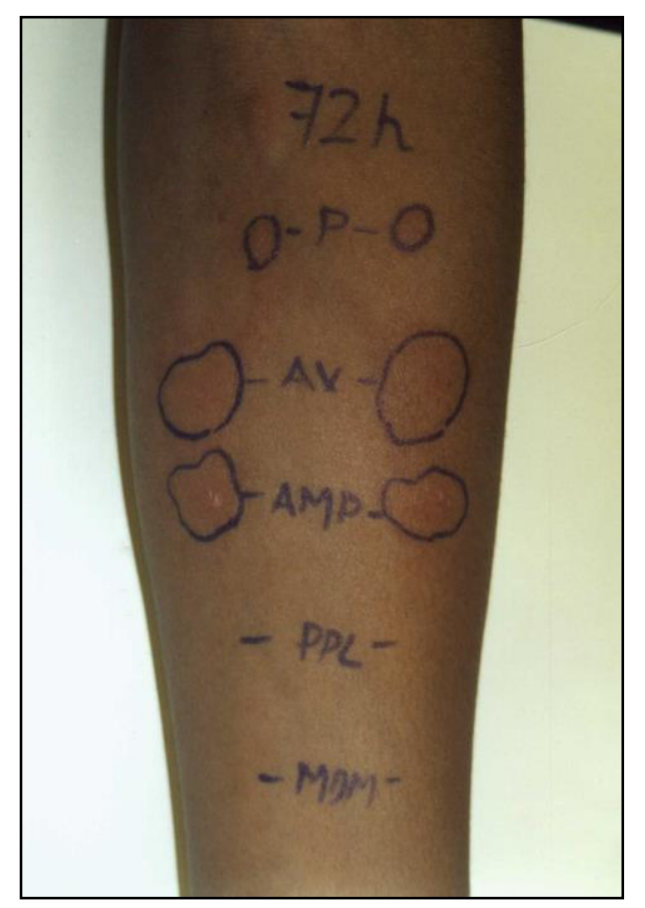

Figura 4b: Paciente RCL - leitura de 72 horas teste intradérmico positivo para ampicilina, amoxicilina e penicilina 


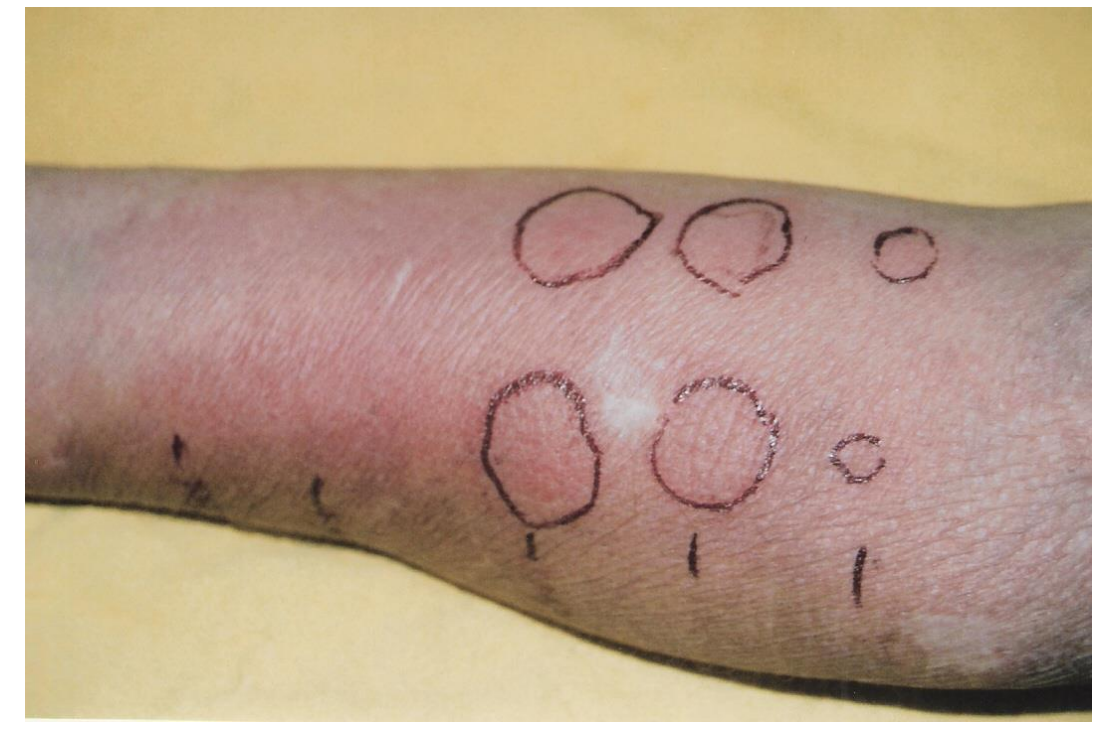

Figura 4c: Paciente WOF - leitura 72 horas teste intradérmico positivo para ampicilina, amoxicilina e penicilina

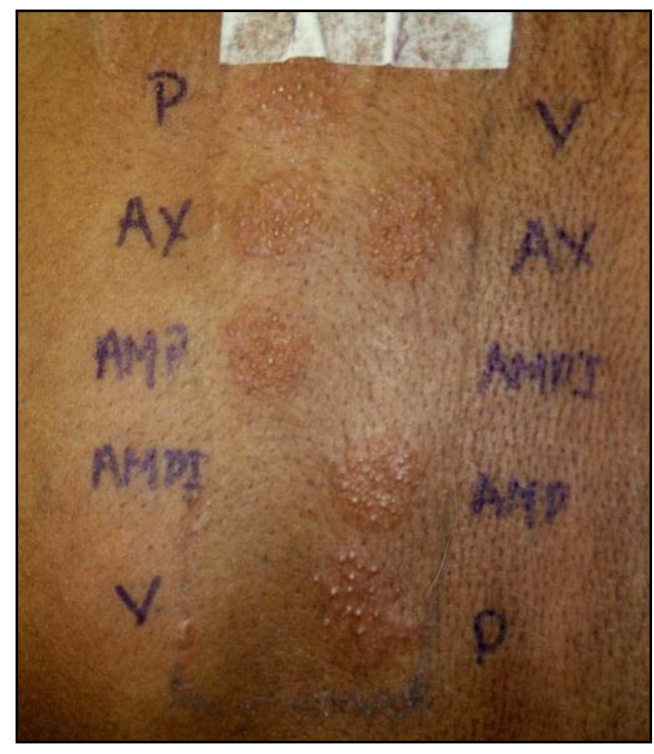

Figura 5a : Paciente RCL - teste de contato leitura de 72 horas positivo para ampicilina, amoxicilina e penicilina 


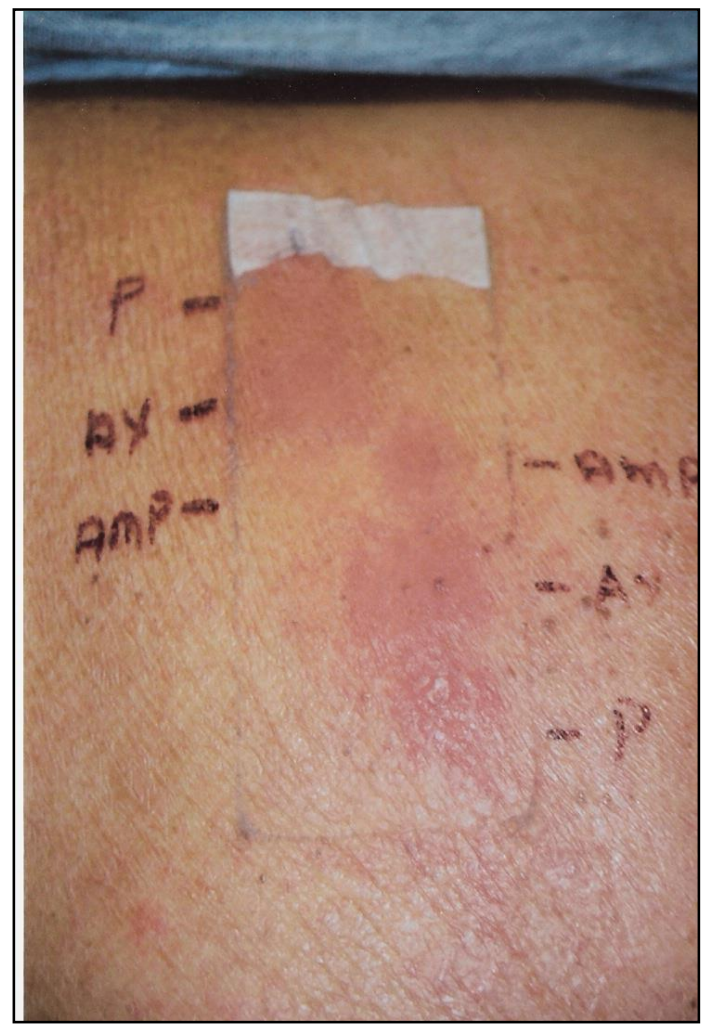

Figura 5b: Paciente WOF - leitura 72 horas teste de contato positivo para ampicilina, amoxicilina e penicilina

\section{Determinação sérica de IgE específica in vitro:}

A determinação sérica de $\lg E$ específica sérica para penicilina $\mathrm{G}$ (c1), ampiciloil (c5) e amoxaciloil (c6) foi negativa em todos os pacientes e controles $(<0,35 \mathrm{kU} / \mathrm{l})$. 


\section{Proliferação linfocitária:}

A proliferação linfocitária mostrou-se positiva em somente 2 controles (13\%) e 10 pacientes (50\%). Um dos pacientes apresentou mononucleose infecciosa durante o exantema induzido por amoxicilina e seu estudo de proliferação linfocitária foi negativo. A paciente APG, cuja história era de exantema induzido por amoxicilina, apresentou testes cutâneos de leitura tardia positivos com amoxicilina, ampicilina e penicilina (figura 1a e 1b), porém, nos experimentos de proliferação, houve resultado positive somente com ampicilina.

As tabelas $5 a, 5 b$ e $5 c$ mostram a média do índice de estimulação linfocitária para cada um dos medicamentos em suas diferentes concentrações, desvio padrão e comparação destas médias entre pacientes e controles, assim como sua significância estatística. Houve diferença estatisticamente significante entre as médias do índice de estimulação somente com ampicilina nas concentrações de 125 e $250 \mathrm{mcg} / \mathrm{ml}$. 
Tabela 5a: Média do índice de proliferação com ampicilina em diferentes concentrações, desvio padrão e comparação entre pacientes e controles:

\begin{tabular}{|c|c|c|c|c|c|}
\hline & Grupo & $\mathbf{N}$ & Média & $\begin{array}{l}\text { Desvio } \\
\text { padrão }\end{array}$ & $\begin{array}{l}\text { p(intervalo de } \\
\text { confiança } \\
95 \%)\end{array}$ \\
\hline \multirow[t]{2}{*}{$\mathrm{AMP}_{1} 1000$} & Controles & 15 & 10,2267 & 27,58790 & ,712 \\
\hline & Pacientes & 20 & 13,1950 & 19,57892 & \\
\hline \multirow[t]{2}{*}{ AMP_500 } & Controles & 15 & 1,8733 & 1,03542 & ,052 \\
\hline & Pacientes & 20 & 5,6950 & 7,24718 & \\
\hline \multirow[t]{2}{*}{ AMP_250 } & Controles & 15 & 1,8400 & ,79084 & ,042 \\
\hline & Pacientes & 20 & 3,8750 & 3,65036 & \\
\hline \multirow[t]{2}{*}{ AMP_125 } & Controles & 15 & 1,3133 & ,41034 & ,031 \\
\hline & Pacientes & 20 & 3,0150 & 2,89178 & \\
\hline
\end{tabular}

Comparação entre as médias do índice de estimulação na proliferação linfocitária com ampicilina entre pacientes e controles. Observa-se diferença estatisitcamente significante somente nas concentrações de 250 e $125 \mathrm{mcg} / \mathrm{ml}$ de ampicilina 
Tabela 5b: Média do índice de proliferação com amoxicilina em diferentes concentrações, desvio padrão e comparação entre pacientes e controles:

\begin{tabular}{|c|c|c|c|c|c|}
\hline & grupo & $\mathbf{N}$ & Média & $\begin{array}{l}\text { Desvio } \\
\text { padrão }\end{array}$ & $\begin{array}{l}\text { p(intervalo de } \\
\text { confiança } \\
95 \%)\end{array}$ \\
\hline \multirow[t]{2}{*}{$A X \_1000$} & Controle & 15 & 1,9200 & 1,09948 & ,088 \\
\hline & Pacientes & 20 & 3,4750 & 3,28279 & \\
\hline \multirow[t]{2}{*}{ AX_500 } & Controle & 15 & 1,6333 & ,62868 & ,054 \\
\hline & Pacientes & 20 & 3,3950 & 3,35692 & \\
\hline \multirow[t]{2}{*}{ AX_250 } & Controle & 15 & 1,4533 & ,52081 & ,056 \\
\hline & Pacientes & 20 & 3,3850 & 3,73057 & \\
\hline \multirow[t]{2}{*}{ AX_125 } & Controle & 15 & 1,3333 & ,32660 & ,055 \\
\hline & Pacientes & 20 & 3,1000 & 3,41298 & \\
\hline
\end{tabular}

Comparação entre as médias do índice de estimulação na proliferação linfocitária com amoxixilina entre pacientes e controles. Não houve diferença estatisticamente significante entre as médias em nenhuma das concentrações de amoxicilina testadas 
Tabela 5c: Média do índice de proliferação com penicilina em diferentes concentrações, desvio padrão e comparação entre pacientes e controles:

\begin{tabular}{|c|c|c|c|c|c|}
\hline & Grupo & $\mathbf{N}$ & Média & $\begin{array}{l}\text { Desvio } \\
\text { padrão }\end{array}$ & $\begin{array}{l}\text { p (intervalo de } \\
\text { confiança 95\%) }\end{array}$ \\
\hline \multirow[t]{2}{*}{ PEN_1000 } & Controle & 15 & 1,6667 & 1,33131 & $\overline{, 064}$ \\
\hline & Pacientes & 20 & 4,7650 & 6,11988 & \\
\hline \multirow[t]{2}{*}{ PEN_500 } & Controle & 15 & 1,6667 & ,87396 & , 123 \\
\hline & Pacientes & 20 & 4,6550 & 7,23576 & \\
\hline \multirow[t]{2}{*}{ PEN_250 } & Controle & 15 & 1,3267 & ,35550 & , 122 \\
\hline & Pacientes & 20 & 3,9095 & 6,26347 & \\
\hline \multirow[t]{2}{*}{ PEN_125 } & Controle & 15 & 1,2133 & ,33566 & , 126 \\
\hline & Pacientes & 20 & 3,1800 & 4,82031 & \\
\hline
\end{tabular}

Comparação entre as médias do índice de estimulação na proliferação linfocitária com penicilina entre pacientes e controles. Não houve diferença estatisticamente significante entre as médias em nenhuma das concentrações de penicilina testadas

As figuras $6 a, 6 b$ e $6 c$ mostram os padrões individuais de proliferação linfocitária para cada droga em suas diferentes concentrações e comparação entre suas médias. 
Figura 6a: Média do índice de estimulção (I.E.) na proliferação linfocitária com ampicilina em diferentes concentrações: Pacientes $X$ Controles

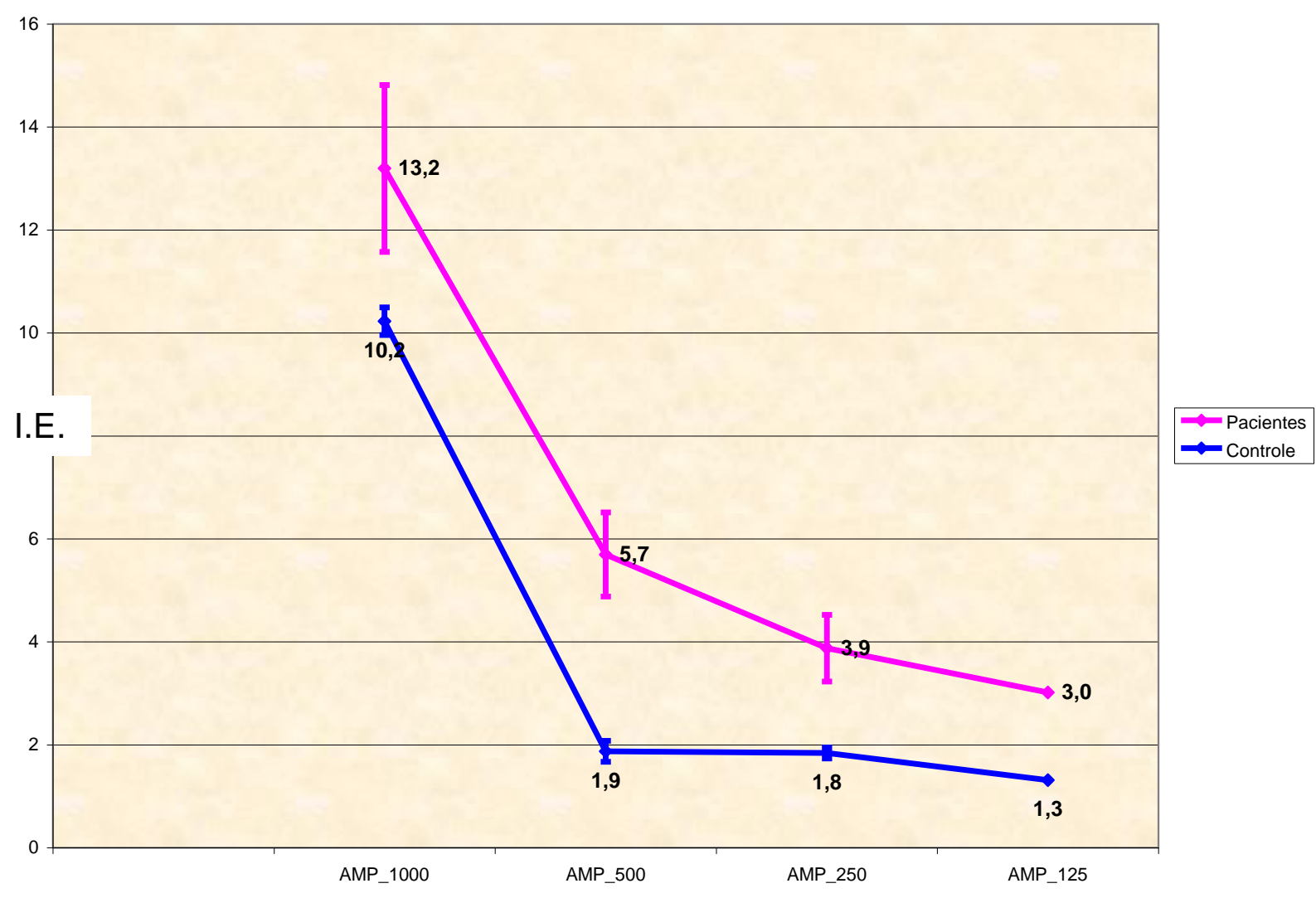

$(\mu \mathrm{g} / \mathrm{ml})$

Variação da média do índice de estimulação na transformação blástica de linfócitos em função da concentração de ampicilina em cultura de linfócitos de pacientes comparado com indivíduos controle. 
Padrão individual de proliferação com ampicilina - Controles

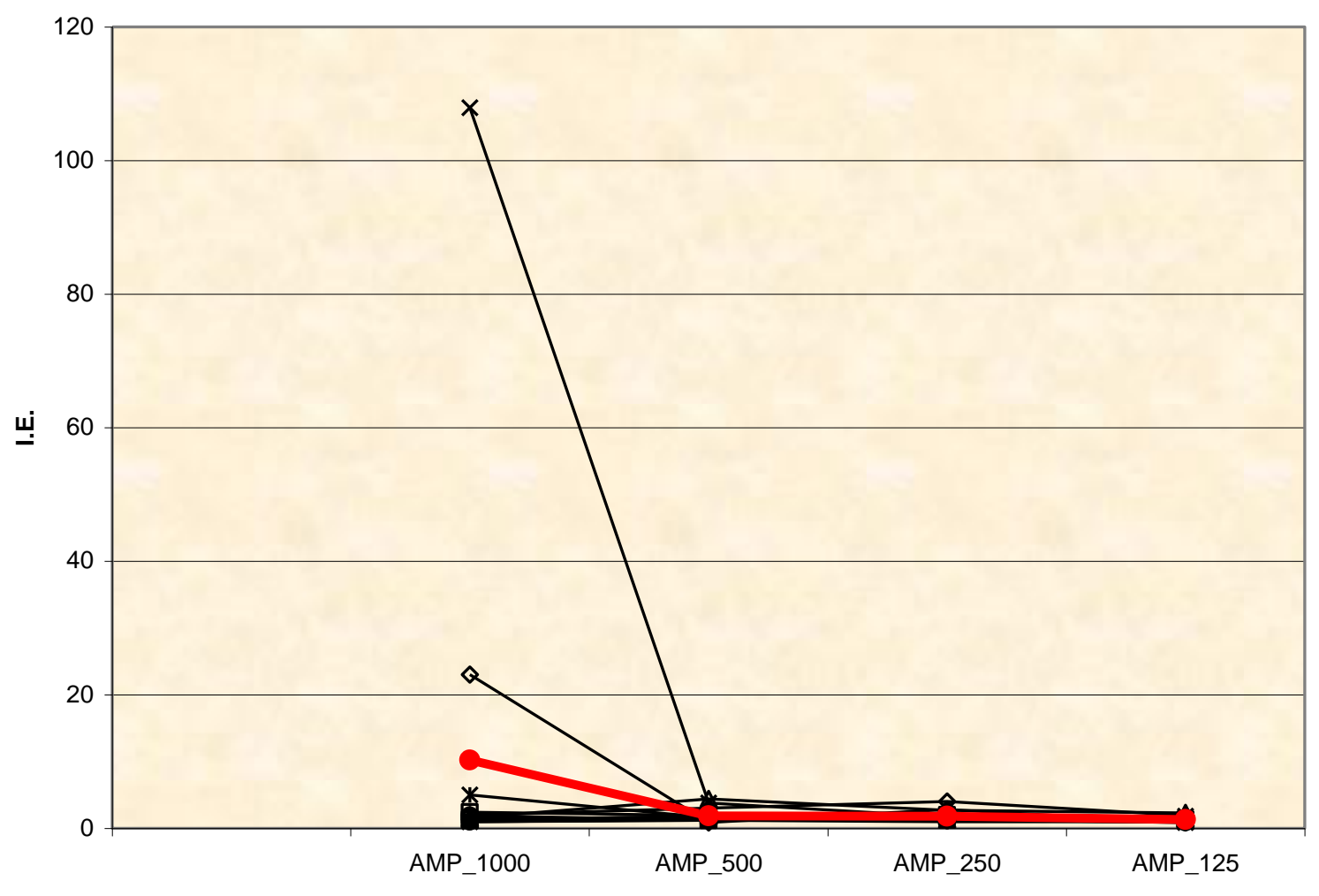

$(\mu \mathrm{g} / \mathrm{ml})$

Padrão individual da proliferação linfocitária com diferentes concentrações de ampicilina no grupo controle. A linha vermelha representa a média do índice de estimulação para o grupo em cada uma das concentrações. 
Padrão individual de proliferação com ampicilina - Pacientes

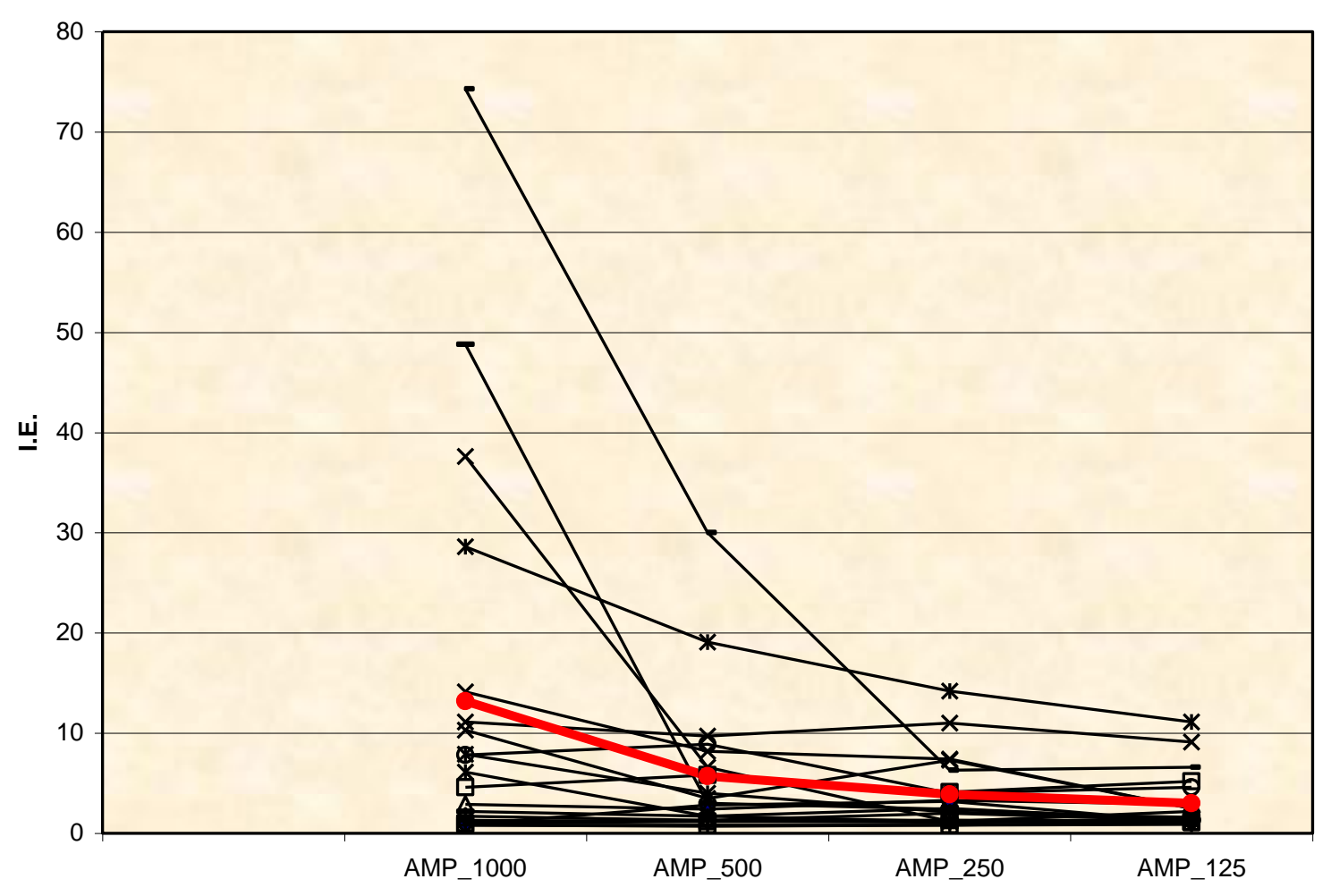

$(\mu \mathrm{g} / \mathrm{ml})$

Padrão individual da proliferação linfocitária com diferentes concentrações de ampicilina no grupo de pacientes. A linha vermelha representa a média do índice de estimulação para o grupo em cada uma das concentrações. 
Figura 6b: Média do índice de estimulção (I.E.) na proliferação linfocitária com amoxicilina em diferentes concentrações: Pacientes $X$

\section{Controles}

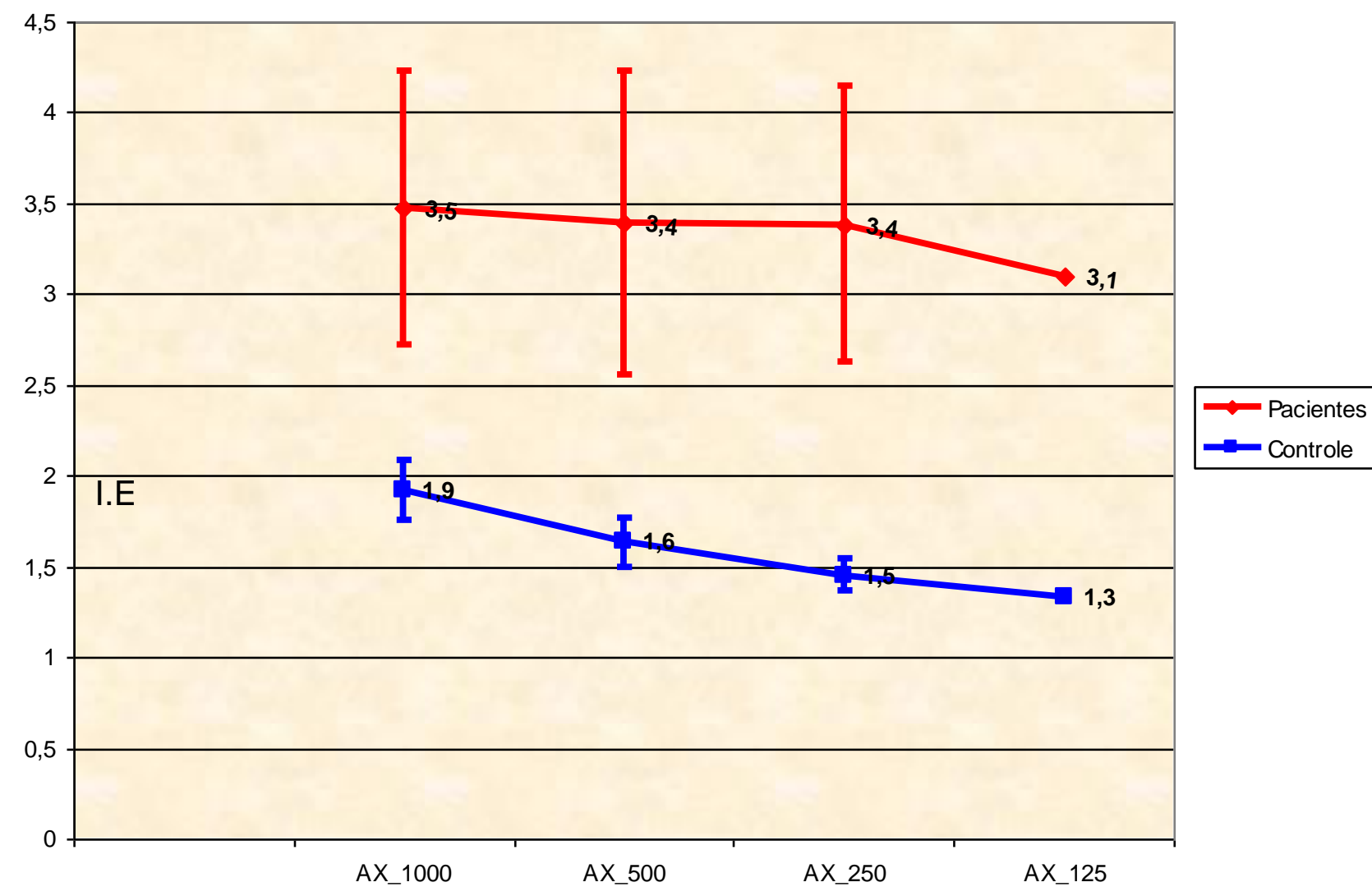

$(\mu \mathrm{g} / \mathrm{ml})$

Variação da média do índice de estimulação na transformação blástica de linfócitos em função da concentração de amoxicilina em cultura de linfócitos de pacientes comparado com indivíduos controle. 
Padrão individual de proliferação com amoxicilina - Controles

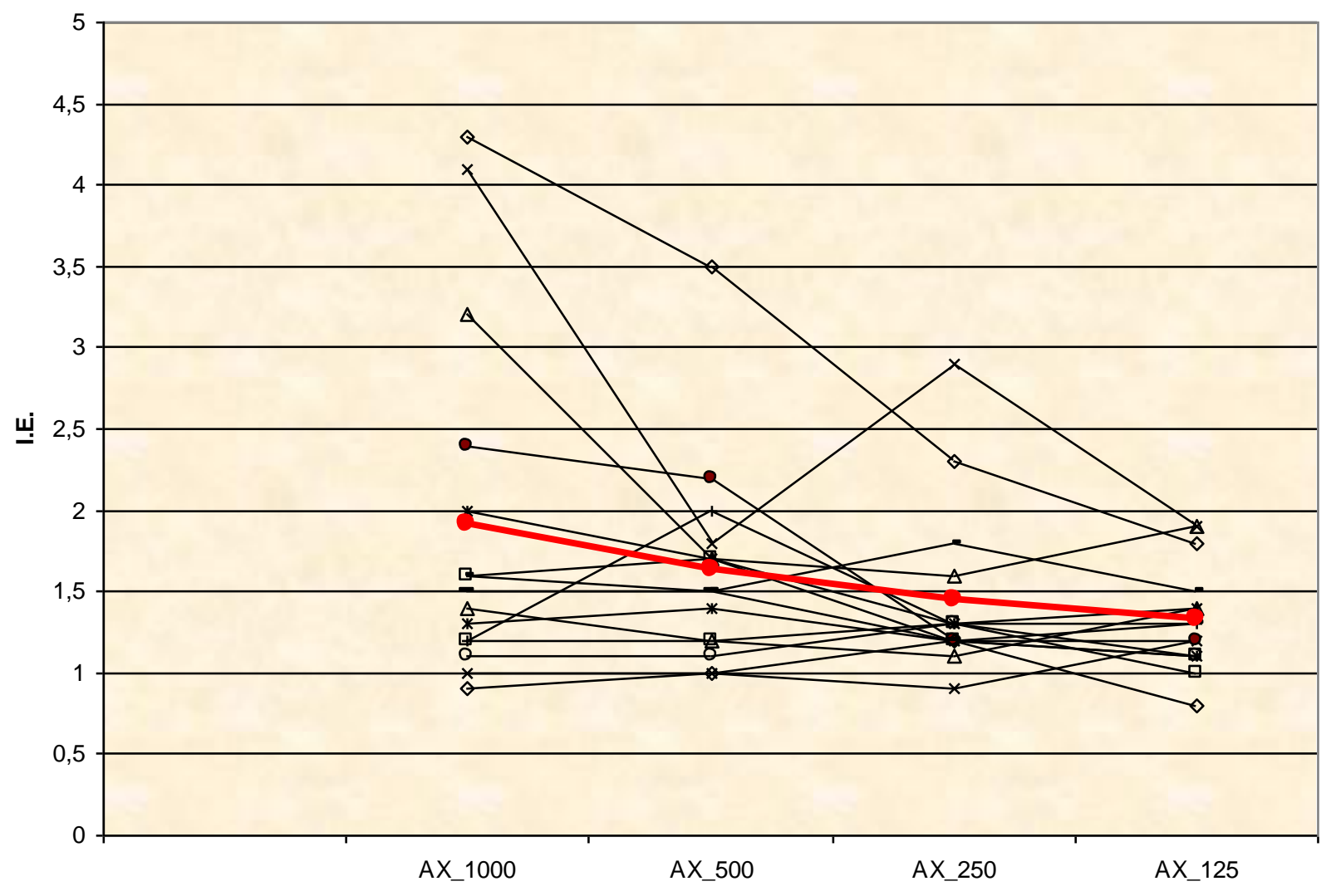

$(\mu \mathrm{g} / \mathrm{ml})$

Padrão individual da proliferação linfocitária com diferentes concentrações de amoxicilina no grupo controle. A linha vermelha representa a média do índice de estimulação para o grupo em cada uma das concentrações. 
Padrão individual de proliferação com amoxicilina - Pacientes

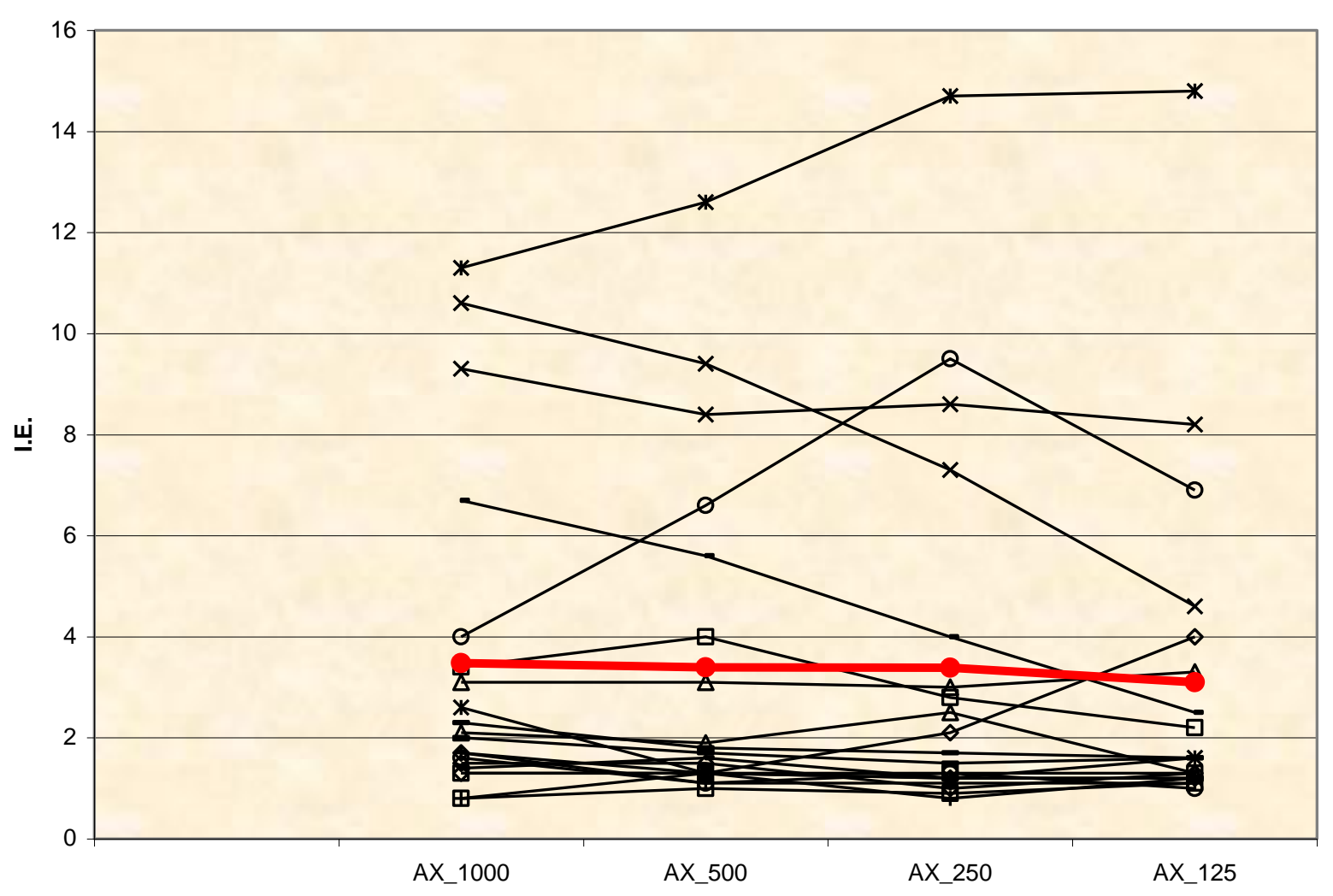

$(\mu \mathrm{g} / \mathrm{ml})$

Padrão individual da proliferação linfocitária com diferentes concentrações de amoxicilina no grupo de pacientes. A linha vermelha representa a média do índice de estimulação para o grupo em cada uma das concentrações. 
Figura 6c: Média do índice de estimulção (I.E.) na proliferação linfocitária com penicilina em diferentes concentrações: Pacientes $X$

\section{Controles}

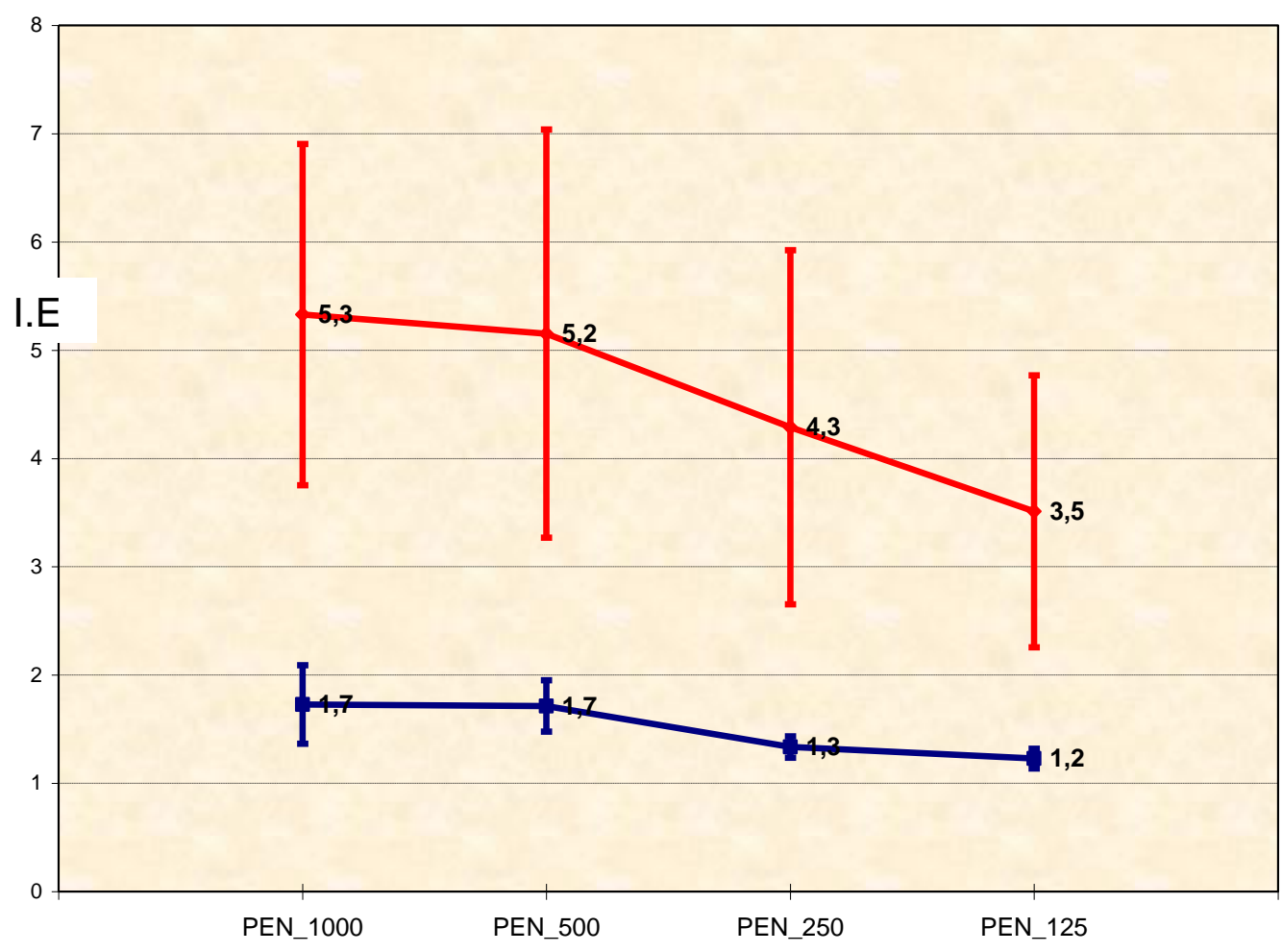

$(\mu \mathrm{g} / \mathrm{ml})$

Variação da média do índice de estimulação na transformação blástica de linfócitos em função da concentração de penicilina em cultura de linfócitos de pacientes comparado com indivíduos controle. 
Padrão individual de proliferação com penicilina - Controles

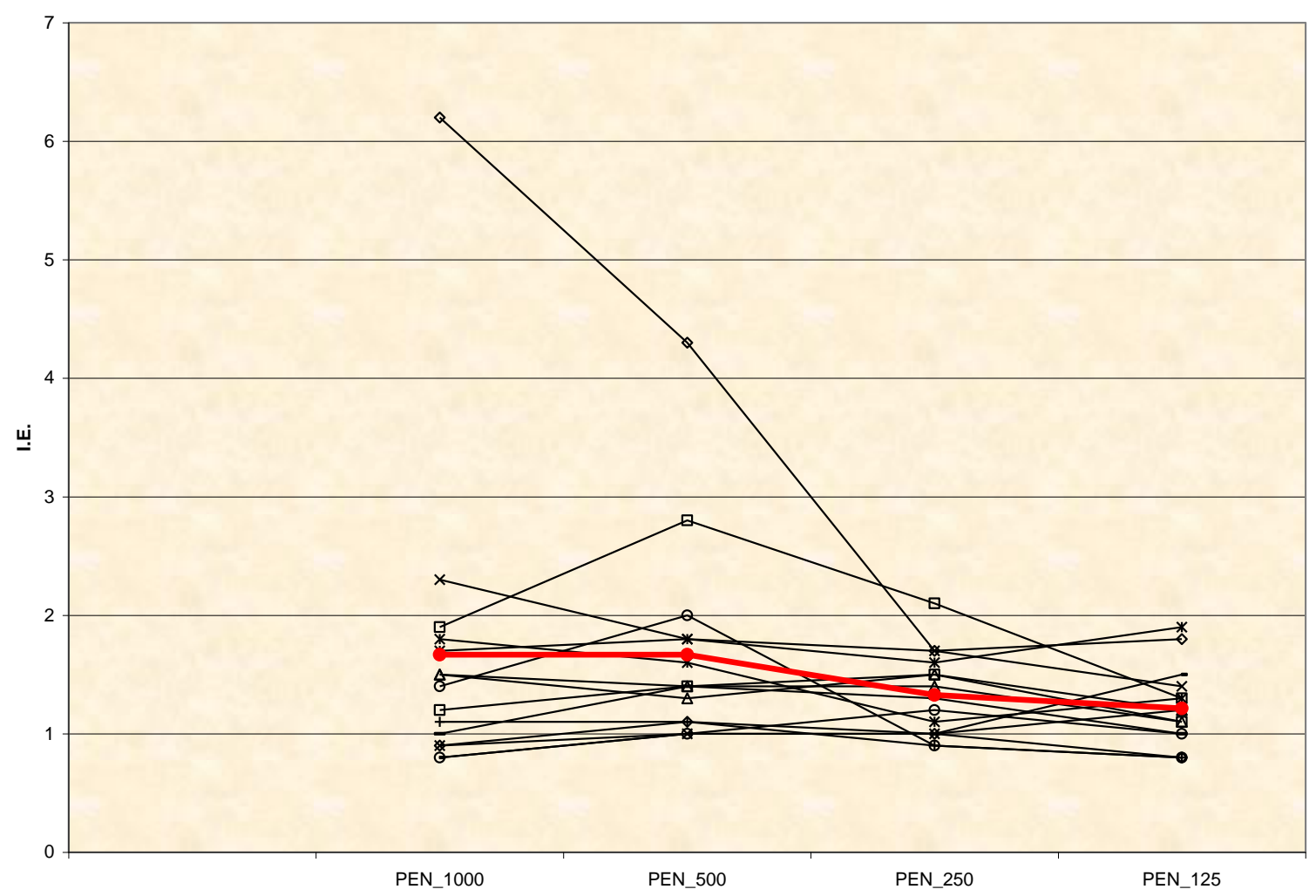

$(\mu \mathrm{g} / \mathrm{ml})$

Padrão individual da proliferação linfocitária com diferentes concentrações de penicilina no grupo controle. A linha vermelha representa a média do índice de estimulação para o grupo em cada uma das concentrações. 
Padrão individual de proliferação com penicilina - Pacientes

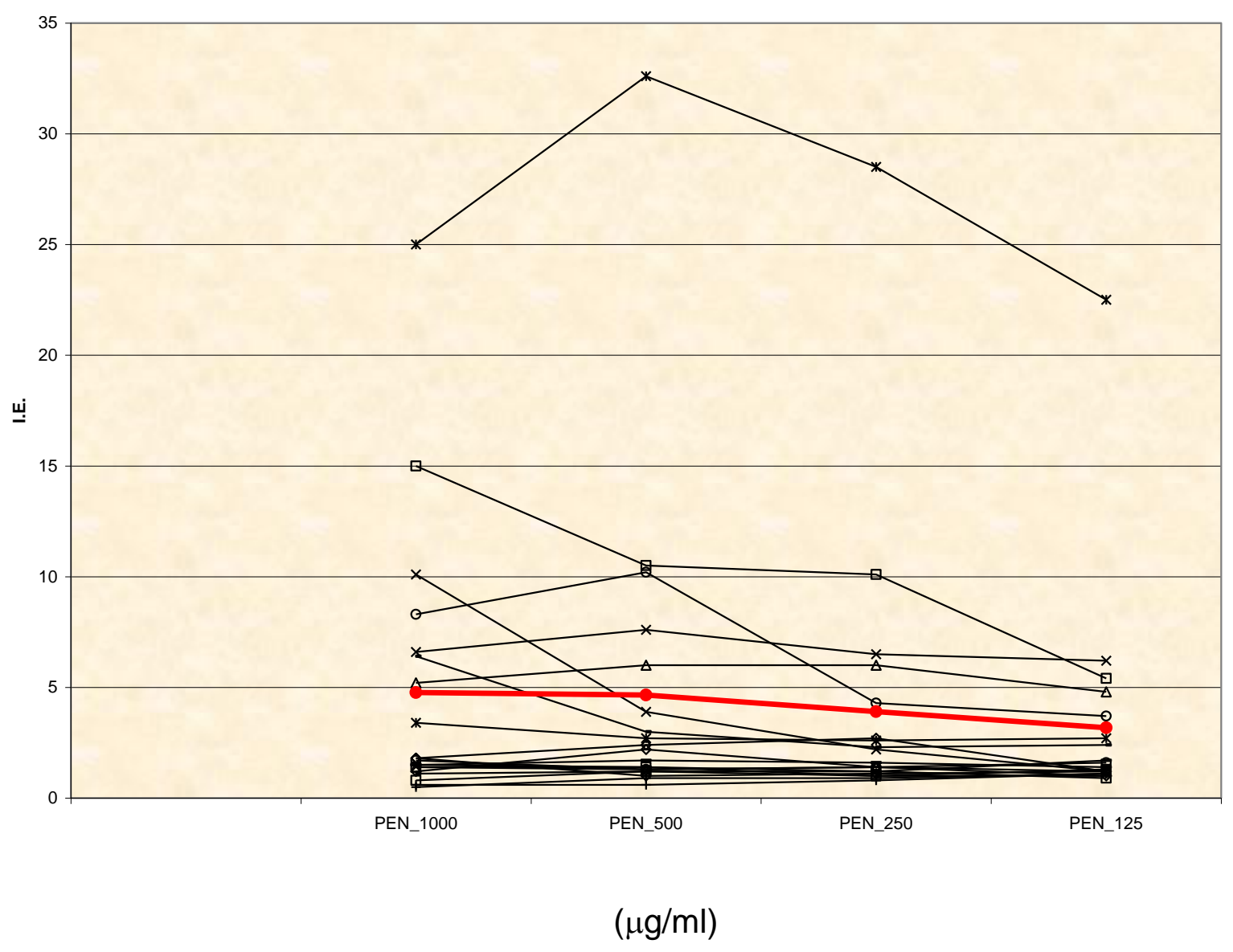

Padrão individual da proliferação linfocitária com diferentes concentrações de penicilina no grupo de pacientes. A linha vermelha representa a média do índice de estimulação para o grupo em cada uma das concentrações. 
A sensibilidade, especificidade, valores preditivo positivo e negativo da proliferação linfocitária para ampicilina, amoxicilina e penicilina em sua diferentes concentrações estão expressas nas tabelas 6a, 6b e 6c.

Tabela 6a: Sensibilidade, especificidade, valor preditivo positivo e negativo da proliferação linfocitária com ampicilina em diferentes concentrações

\begin{tabular}{|l|r|r|r|r|}
\hline Droga / Concentração & AMP 1000 & AMP 500 & AMP 250 & AMP 125 \\
\hline Sensibilidade (\%) & 55 & 50 & 45 & 25 \\
\hline Especificidade (\%) & 80 & 85 & 85 & 100 \\
\hline Valor Preditivo Positivo (\%) & 78 & 83 & 90 & 100 \\
\hline Valor Preditivo Negativo (\%) & 57 & 56,5 & 56 & 50 \\
\hline
\end{tabular}

Tabela 6b: Sensibilidade, especificidade, valor preditivo positivo e negativo da proliferação linfocitária com amoxicilina em diferentes concentrações

\begin{tabular}{|l|r|r|r|r|}
\hline Droga / Concentração & AX 1000 & AX 500 & AX 250 & AX 125 \\
\hline Sensibilidade (\%) & 35 & 35 & 30 & 30 \\
\hline Especificidade (\%) & 85 & 85 & 100 & 100 \\
\hline Valor Preditivo Positivo (\%) & 77 & 87,5 & 100 & 100 \\
\hline Valor Preditivo Negativo (\%) & 50 & 52 & 52 & 52 \\
\hline
\end{tabular}

Tabela 6c: Sensibilidade, especificidade, valor preditivo positivo e negativo da proliferação linfocitária com pencicilina em diferentes concentrações

\begin{tabular}{|l|r|r|r|r|}
\hline Droga / Concentração & PEN 1000 & PEN 500 & PEN 250 & PEN 125 \\
\hline Sensibilidade (\%) & 40 & 35 & 25 & 25 \\
\hline Especificidade (\%) & 85 & 85 & 100 & 100 \\
\hline Valor Preditivo Positivo (\%) & 89 & 87,5 & 100 & 100 \\
\hline Valor Preditivo Negativo (\%) & 54 & 52 & 50 & 50 \\
\hline
\end{tabular}


A sensibilidade dos experimentos de proliferações linfocitária variou entre $25 \%$ com penicilina na concentração de $250 \mu \mathrm{g} / \mathrm{ml}$ até $55 \%$ com ampicilina $1000 \mu \mathrm{g} / \mathrm{ml}$. Sua especificidade foi de $80 \%$ a $100 \%$ como demonstrado na tabela acima. $\mathrm{O}$ valor preditivo positivo foi elevado:77 a 100\%. Entretanto, o valor preditivo negativo não foi superior a $50 \%$.

\section{Dosagem de citocinas no sobrenadante da cultura de linfócitos:}

A dosagem de citocinas no sobrenadante da cultura foi realizada em todos os pacientes e controles. Trinta e cinco porcento dos pacientes e $6 \%$ dos indivíduos controle apresentaram níveis detectáveis de IFN- $\gamma$. No que diz respeito ao TNF- $\alpha$, encontramos resultados positivos em $95 \%$ dos pacientes e $60 \%$ dos controles. Nenhum dos indivíduos do grupo controle apresentou níveis elevados de IL-5 no sobrenadante da cultura linfocitária, contra $30 \%$ dos pacientes. A sensibilidade, especificidade, valores preditivos positivo e negativo do experimento são expressos na tabela 7a, 7b e 7c.

Tabela 7 a: Sensibilidade, especificidade, valor preditivo positivo e negativo da dosagem de IFN-gama no sobrenadante da cultura linfocitária

\begin{tabular}{|l|r|}
\hline & IFN-gama \\
\hline Sensibilidade & $35 \%$ \\
\hline Especificidade & $93 \%$ \\
\hline Valor Preditivo Positivo & $87,50 \%$ \\
\hline Valor Preditivo Negativo & $52 \%$ \\
\hline
\end{tabular}


Tabela 7b: Sensibilidade, especificidade, valor preditivo positivo e negativo da dosagem de TNF-alfa no sobrenadante da cultura linfocitária

\begin{tabular}{|l|r|}
\hline & TNF-alfa \\
\hline Sensibilidade & $95 \%$ \\
\hline Especificidade & $40 \%$ \\
\hline Valor Preditivo Positivo & $68 \%$ \\
\hline Valor Preditivo Negativo & $86 \%$ \\
\hline
\end{tabular}

Tabela 7c: Sensibilidade, especificidade, valor preditivo positivo e negativo da dosagem de IL-5 no sobrenadante da cultura linfocitária

\begin{tabular}{|l|r|}
\hline & IL-5 \\
\hline Sensibilidade & $30 \%$ \\
\hline Especificidade & $100 \%$ \\
\hline Valor Preditivo Positivo & $100 \%$ \\
\hline Valor Preditivo Negativo & $52 \%$ \\
\hline
\end{tabular}

Um resumo de todos os experimentos in vivo e in vitro realizados com todos os pacientes e controles estão expressos na tabela 8a e 8b (anexo 3) 


\section{Discussão:}

Os antibióticos da classe dos beta-lactâmicos constituem causa freqüente de reações adversas a medicamentos mediadas por mecanismos imunológicos. O reconhecimento destes antibióticos por células $\mathrm{T}$ em pacientes com reações tardias é de grande relevância e, estudos recentes corroboram com este achado (Depta, 2004).

Como descrito anteriormente, atopia não constitui um fator de risco para reação alérgica a antibióticos beta-lactâmicos. Alguns estudos mostram a existência de predisposição familiar para o desenvolvimento de alergia a drogas (Adkinson, 1984; Kurtz, 1999), porém, não conseguimos confirmar estes achados. O uso contínuo de medicações não foi associado a reações tardias com aos antibióticos estudados. Nós esperávamos o oposto, uma vez que o número de medicações de uso concomitante poderia contribuir para elevar a freqüência de reações adversas a medicamentos.

Adkinson, 1984, relatou em seus estudos sobre fatores de risco para reações a drogas que exposições repetidas a um determinado medicamento não estão associadas com risco maior de reações adversas e, em nosso estudo, não encontramos diferença significativa no número de cursos de antibióticos utilizados por pacientes e controles nos últimos 5 anos.

Os testes cutâneos intradérmicos de leitura tardia foram positivos em somente 3 pacientes (15\%), uma percentagem inferior àquela encontrada em outros estudos que mostraram uma positividade entre 36,8 (Macy, 1998) a 52\% (Romano, 1999) em pacientes com história de reações tardia a 
antibióticos beta-lactâmicos. A média de intervalo de tempo entre a reação aguda e a realização dos testes pode não ser uma das razões para esta diferença, uma vez que nossos pacientes foram testados com menos que 12 meses da reação aguda (média de 5,4 meses). Talvez exista alguma característica populacional envolvida como anteriormente sugerido por Primeau, 2002, que não encontrou resultados positivos nos testes intradérmicos e de contato em 15 pacientes com história de exantema máculo-papular induzido por antibióticos beta-lactâmicos.

Nenhum dos pacientes estudados apresentou testes cutâneos de leitura imediata positivos ou detecção de IgE sérica específica positiva. Isto demonstra a ausência de sensibilização mediada por lgE nestes indivíduos.

Assim como em outros estudos (Schnyder, 2000), nenhum dos nossos pacientes ou controles apresentou reação positiva com PPL e MDM, nem mesmo aqueles pacientes com teste intradérmico positivo com ampicilina, amoxicilina e penicilina. Estes resultados podem estar relacionados à natureza do carreador ou ao fato da droga envolvida em todas as reações ser a amoxicilina. A concentração do MDM pode também constituir um problema uma vez que estudos indicam que as reações positivas são vistas com mais freqüência com uso de concentrações maiores daquelas utilizadas nos extratos disponíveis comercialmente (Schnyder, 2000)

O teste de contato foi positivo nos mesmos 3 pacientes que apresentaram testes cutâneos intradérmicos de leitura tardia positivos. Não 
houve nenhum teste de contato positivo no grupo controle. A positividade dos testes de contato em pacientes com história de reação tardia com antibióticos beta-lactâmicos na literatura, é variável. Em pacientes com alta probabilidade de uma determinada droga estar envolvida na reação, a positividade do teste de contato pode variar de 31,7 a $50 \%$ (Barbaud, 2001). Resultados relevantes dependem da concentração utilizada da droga, veículo e local de aplicação dos testes. Encontramos uma positividade de $15 \%$ do teste de contato no grupo de pacientes, inferior àquela referida na literatura. A concentração das drogas utilizadas, veículo e local de aplicação dos testes foram os mesmos dos trabalhos anteriormente realizados e, desta forma, não existem diferenças técnicas na realização do procedimento. Da mesma forma que os testes cutâneos intradérmicos de leitura tardia, Primeau, 2000, não encontrou nenhum teste de contato positivo em 15 pacientes com história de exantema maculo-paular induzido por antibióticos beta-lactâmicos. Talvez, variações populacionais possam estar envolvidas nestas diferenças.

O exantema máculo-papular é a lesão cutânea mais associada a reações adversas a medicamentos, principalmente causadas por antibióticos do grupo das penicilinas (Bigby, 2001). Nosso estudo mostra que o exantema máculo-papular foi a lesão mais frequentemente descrita pelos pacientes durante a reação aguda. A amoxicilina é o beta-lactâmico mais comumente usado na nossa prática diária e, provavelmente, é uma das causas para a alta freqüência de reações adversas a estes medicamentos. 
A sensibilidade da proliferação linfocitária com antibióticos betalactâmicos é muito variável, dependendo das características do estudo e população analisada. Em nossos experimentos, $50 \%$ dos pacientes apresentaram índice de estimulação superior a 3,0 com pelo menos um dos antibióticos estudados. A sensibilidade com a amoxicilina (a droga mais envolvida nas reações) variou de 30 a $35 \%$, dependendo da concentração da mesma. Esta porcentagem é inferior àquela relatada por Nyfeler \& Pichler, em seu estudo publicado em 1997 , de $74 \%$, porém, isso pode ser explicado pelas diferenças no processo de seleção dos pacientes, nível de corte escolhido para o índice de estimulação e condições nas quais a cultura linfocitária foi realizada. Apesar desta diferença de sensibilidade da proliferação linfocitária entre nosso estudo e outros já publicados, acreditamos que este teste diagnóstico in vitro constitui um método útil na identificação de indivíduos alérgicos a peniclina, especialmente aqueles com história de reações tardias. A proliferação linfocitária mostrou-se mais produtiva quando comparado com os testes cutâneos.

Por outro lado, a especificidade da cultura de linfócitos foi alta: 80 a100\% com amoxicilina (em diferentes concentrações). Estes achados são condizentes com outros grupos (Luque, 2001; Nyfeler, 1997).

Nossos experimentos com proliferação linfocitária mostraram uma heteregenicidade na resposta antigênica. Alguns pacientes apresentaram resposta específica com amoxicilina e boa tolerância à penicilina, enquanto outros indivíduos responderam a ambas as drogas. Além disso, nossos resultados mostram que nas reações alérgicas não imediatas aos beta- 
lactâmicos não existe uma curva dose-resposta clara, e a concentração da drogas que induziu proliferação máxima variou entre os pacientes.

As bases científicas da proliferação linfocitária foram bem estabelecidas nos últimos anos e sua utilidade foi demonstrada em diversas doenças e com diferentes drogas. Desta forma, este teste tem contribuído muito para a melhor compreensão da imunopatologia das reações imunológicas a drogas. Se realizado de forma correta, este teste diagnóstico apresenta algumas vantagens: é um teste laboratorial (in vitro), seguro e pode ser positive em reações a medicamentos de diferentes mecanismos.

Entretanto, sua aplicação como um exame de rotina é ainda controverso. O mesmo é verdadeiro para a maioria dos testes diagnósticos em alergia a medicamentos. Estas limitações decorrem da grande heterogenidade das reações de hipersensibilidade a drogas, e um teste isolado não é capaz de demonstrar sensibilização ao medicamento envolvido com segurança suficiente. Além disso, experimentos de proliferação linfocitária requerem experiência em técnicas de manejo celular, equipamentos caros e um profundo conhecimento em farmacologia e imunologia do indivíduo que interpretará os resultados.

Um estudo de proliferação linfocitária positivo contribui para o diagnóstico de alergia a droga. Porém, uma vez que a sensibilidade do teste é limitada, um resultado negativo não exclui hipersensibilidade a drogas. Assim, torna-se evidente que são necessárias novas pesquisas a fim de 
simplificar estes testes e melhor definir as drogas e doenças para as quais a proliferação linfocitária seria mais útil.

Apesar de terem sido demonstrados diversos achados in vitro nas reações alérgicas a medicamentos, estes nem sempre reproduzem o que ocorre in vivo, e discrepâncias existem. Uma das estratégias para o melhor entendimento das reações adversas imunológicas a drogas envolve estudos da expressão de citocinas em células mononucleares periféricas de indivíduos com reações imediatas ou tardias a medicamentos. Esta abordagem consiste na quantificação da expressão e produção de algumas citocinas relevantes (IFN-gamma, TNF-alpha and IL-5) através de ELISA ou RT-PCR. A sensibilidade do método ELISA possui limitações. Sabe-se que o uso de ambas as técnicas constitui uma abordagem mais completa.

Em nosso estudo, 35\% dos pacientes e somente $6 \%$ dos controles apresentaram resultados positivos para a detecção de IFN- $\gamma$. No caso do TNF- $\alpha$, encontramos $95 \%$ de pacientes e $60 \%$ dos controles com resultados positivos. Nenhum dos controles apresentou detecção de IL-5 positiva, enquanto $30 \%$ dos pacientes o fizeram.

Outros grupos demonstram uma positividade de $50 \%$ quando a detecção de RNAm para IFN- $\gamma$ foi utilizada. Nossos achados de sensibilidade para IL-5 foram muito inferiores quando comparada a outros autores. Provavelmente, estas discrepâncias decorrem do método utilizado. 


\section{Conclusões:}

Os testes cutâneos de leitura tardia (intradérmico e de contato) não foram eficazes para o diagnóstico da urticária tardia e exantema maculopapular induzidos por antibióticos beta-lactâmicos.

A proliferação linfocitária apresentou alta especificidade, porém, baixa sensibilidade para a amoxicilina, a droga envolvida em 100\% das reações.

A detecção de citocinas no sobrenadante da cultura de linfócitos mostrou resultados variáveis, dependendo da citocina estudada. A detecção de IFN-gama apresentou baixa sensibilidade e alta especificidade, da mesma forma que a IL-5. Por outro lado, A detecção de TNF-alfa mostrou-se muito sensível, porém, pouco específico.

Concluímos que, uma vez que a imunopatogenia das reações de hipersensibilidade a drogas é complexa, seu diagnóstico se comporta da mesma forma. Somente uma abordagem combinada utilizando história clínica detalhada, testes cutâneos de leitura imediata e tardia quando disponíveis, testes in vitro quando possível e de provocação, podem contribuir para elucidação diagnóstica. 


\section{Referências Bibliográficas:}

Adams, R.C. Patch testing: a recapitulation. J Am Acad Dermatol. 1981; 5:629-643.

Adkinson, N. F. Risk factors for drug allergy. J Allergy Clin Immunol. $1984 ; 74: 567-572$

Adkinson, N. F. Beta-lactam crossreactivity. Clin Exp Allergy. 1998; 28(4): $37-40$.

Bachot, N. Roujeau J.-C. Differential diagnosis of severe cutaneous drug eruptions. Am J Clin Dermatol. 2003; 4(8): 561-572.

Bigby, M. Rates of cutaneous reactions to drugs. Archives of dermatology. 2001; 137(6): 765-770.

Blanca, M., C. Mayorga, et al. Clinical evaluation of Pharmacia CAP System RAST FEIA amoxicilloyl and benzylpenicilloyl in patients with penicillin allergy. Allergy. 2001; 56: 862-870.

Borish, L; Tilles, S.A. Immune Mechanisms of Drug Allergy. Immunology and Allergy Clinics of North América. 1998; 18 (4): 717-729. 
Brander, C., D. Mauri-Hellweg, et al. Heterogeneous T cell response to beta-lactam-modified self-structures are observed in epnicillin-allergic individuals. The Journal of Immunology. 1995; 155: 2670-2678.

Brugnolo, F., F. Annunziato, et al. Highly Th2-skewed cytokine profile of beta-lactam-specific $T$ cells from nonatopic subjects with adverse drug reactions. The Journal of Immunology. 1999; 163: 1053-1059.

Depta, J. P. H., F. Altznauer, et al. Drug interaction with T cell recptors: T cell receptor density determines degree of cross-reactivity. J Allergy Clin Immunol. 2004; 113: 519-527.

De Swarte RD: Drug Allergy. In Patterson R (ed): Allergic Diseases: Diagnosis and Management, ed 3. Philadelphia, JB Lippincott, 1989, p 505

Di Piro JT, Adkinson, NF Jr, Hamilton RG. Facilitation of penicillin haptenization to serum proteins. Antimicrobial Agents and Chemotherapy. 1993; July: 1463-7.

Dracoulakis, M., Criado, R.F.J., Aun, W.T., Mello, J. F. Avaliação das reações adversas cutâneas em pacientes internados no Hospital do Servidor Público Estadual de São Paulo - Francisco Morato de Oliveira. Rev Bras Aler Imunopatol. 2004; 27(4): 136 
Fiszenson-Albala, F., V. Auzerie, et al. A 6-month prospective survey of cutaneous drug reactions in a hospital setting. British Journal of Dermatology. 2003;149(5): 1018-1022.

Friedmann, P. S., M. S. Lee, et al. Mechanisms in cutaneous drug hypersensitivity reactions. Clin Exp Allergy. 2003; 33: 861-872.

Gaspard, I., M.-T. Guinnepain, et al. IL-4 and IFN-gamma mRNA induction in human peripheral lymphocytes specific for beta-lactam antibiotics in immediated or delayed hypersensitivity reactions. Journal of Clinical Immunology. 2000; 20(2): 107-115.

Gruchalla, R. S. Drug metabolism, danger signals, and drug-induced hypersensitivity. J Allergy Clin Immunol. 2001; 108: 475-488.

Halevy, S., A. D. Cohen, et al. Clinical implications of in vitrp drug-induced interferon gamma released from peripheral blood lymphocytes in cutaneous adverse drug reactions. J Am Acad Dermatol. 2005; 52: 254.

Hertl, M., H. Bohlen, et al. Predominance of epidermal CD8+ T lymphocytes in bullous cutaneous reactions caused by beta-lactam antibiotics. J Invest Dermatol. 1993a; 101: 794-799. 
Hertl, M., J. Geisel, et al. Selective generation of T CD8+ T cell clones from the peripheral blood of patients with cutaneous reactions to betalactam antibiotics. British Journal of Dermatology. 1993b; 128: 619-626.

Hunziker, T., U. P. Künzi, et al. Comprehensive hospital drug monitoring (CHDM): adverse skin reactions, a 20years suvey. Allergy. 1997; 52(4): 388-393.

Kuechler, P. C., M. Britschgi, et al. Cytotoxic mechanisms in different forms of T-cell-mediated drug allergies. Allergy. 2004; 59: 613-622.

Kurtz, K. M., T. L. Beatty, et al. Evidence for familial aggregation of immunologic drug reactions. J Allergy Clin Immunol. 1999; 105(1): 184185.

Levine BB Immunologic mechanisms of penicillin allergy. A haptenic model system for the study of allergic disease of man. $\mathrm{N}$ Engl $\mathrm{J}$ Med. $1966 ; 275: 1115-25$.

Luque, I., L. Leyva, et al. In vitro T-cell responses to [beta]-lactam drugs in immediate and nonimmediate allergic reactions. Allergy. 2001; 56(7): 611-618. 
Macy, E. Elective penicillin skin testing and amoxicillin challenge: effect on outpatient antibiotic use, cost, and clinical outcomes. J Allergy Clin Immunol. 1998; 102: 281-285.

Malaman, M. F., Iamnishi, E.M., Ensina, L.F.C., Costa, N. M. X., Criado, R.F.J., Bertocco, M. E. A., Aun, W.T., Mello, J.F. Incidência de reações cutâneas provocadas por drogas. Rer Bras Alerg Imunopatol. 2000; 23(5): TL-17

Merk, H. F., A. Dorfmüller, et al. Delayed Hypersensitivity reactions. Which tests exist? What is the sensitivity and specificity of these tests? ACl International. 2002; 14(5): 194-200.

Neugut, Al, Ghatak, AT, Miller, RL. Anaphylaxis in the United States. An investigation into its epidemiology. Archives of Internal Medicine. 2001; 161(8): 15-21.

Nyfeler, B. and W. J. Pichler The lymphocyte transformation test for the diagnosis of drug allergy: sensitivity and specificity. Clin Exp Allergy. 1997; 27(2): 175-181.

Padovan, E., S. von Greyers, et al. Antigen-dependent and independent IFN-gamma modulation by penicillins. The Jounal of immunology 1999; 162: $1171-1177$. 
Padovan E. T-cell response in penicillin allergy Clinical Experimental Allergy. 1998; 28(4): 33-36.

Pichler, W. J. Delayed drug hypersensitivity reactions. Ann Intern Med. 2003; 139: 683-693.

Pichler, W. J. and J. Tilch The lymphocyte transformation test in diagnosis of drug hypersensitivity."Allergy. 2004; 59: 809-820.

Pichler, W. J. and N. Yawalkar. Allergic reactions to drugs: involvment of T cells. Thorax. 2000; 55(suppl 2): S61-S65.

Posadas, S. J., L. Leyva, et al. Subjects with allergic reactions to drugs show in vivo polarized patterns of cytokine expression depending on the chronology of the clinical reaction. J Allergy Clin Immunol. 2000; 106: 769-776.

Posadas, S. J., A. Padial, et al. Delayed reactions to drugs show levels of perforin, granzyme $B$, and Fas- $L$ to be realted to disease severity. $J$ Allergy Clin Immunol. 2002; 109: 155-161.

Primeau, M.-N., R. G. Hamilton, et al. Negative patch tests and skin tests in patients with delayed cutaneous manifestation to penicillin. J Allergy Clin Immunol. 2002; 109(1): 816. 
Rademarker, M., A. Oakley, et al. Cutaneous adverse drug reaction in a hospital setting. New Zealand Medical Journal. 1995; 108: 165-166.

Romano, A., M. Blanca, et al. Diagnosis of nonimmediated reactions to beta-lactam antibiotics. Allergy. 2004; 59: 1153-1160.

Romano, A., D. Quaratino, et al. A diagnostic protocol for evaluating nonimmediated reactions to aminopenicillins. J Allergy Clin Immunol. 1999; 103: 1186-1190.

Romano, A., D. Quaratino, et al. Aminopenicillin allergy. Archives of Disease in Childhood. 1997; 76(6): 513-517.

Sachs, B., S. Erdmann, et al. Determination of interleukin-5 secretion from drug-specific activated ex vivo peripheral blood mononuclear cells as a test system for the in vitro detection of drug sensitization. Clin Exp Allergy. 2002; 32: 736-744.

Sachs, B. and H. Merk Demonstration and characterization od drugspecific lymphocyte reactivity in drug allergy. ACI International. 2001; 13: 91-98. 
Sachs, B., Al Masaoudi, T., Merk, H. F., Erdmann, S. Combined in vivo and in Vitro approach for the characterization of penicillin-specific polyclonal lymphocyte reactivity: tolerante tests with safe pencillins isnted of challenge with culprit drugs. British Journal of Dermatology. 2004; 151:809-816.

Schnyder, B. and W. J. Pichler. Skin and laboratory tests in amoxicillin and penicillin-induced morbilliform skin eruption. Clin Exp. 2000; Allergy 30: $590-595$.

Sogn, D. D., R. Evans III, et al. Results of the National Institute of Allergy and Infectious Collaborative Clinical Trial to test the predictive value of skin testing with major and minor penicillin derivates in hospitalized adults. Arch Intern Med. 1992; 152: 1025-1032.

Torres, M. J., A. Romano, et al. Diagnostic evaluation of a large group of patients with immediated allergy to penicillin: the role of skin testing. Allergy. 2001; 56(9): 850-856.

Torres, M. J., E. Sánchez-Sabaté, et al. Skin test evaluation in nonimmediated allergic reactions to penicillins. Allergy. 2004; 59: 219224.

Voorhost, R. Perfection of skin testing techinique. Allergy. 1980; 35: 247. 
von Greyerz, S., C. Burkhart, et al. Molecular basis of drug recognition by specific T-cell receptors. Int Arch Allergy Immunol. 1999; 119: 173-180.

Weiss, M. E. and N. F. Adkinson. Drug hypersensitivity. Immunology and Allergy Clinics of North America. 1998; 18(4): 731-741.

Weltzien, H. U. and E. Padovan. Molecular features of penicillin allergy. J Invest Dermatol. 1998; 110: 203-206.

Yawalkar, N., F. Egli, et al. Infiltration of cytotoxic T cells in drug-induced cutaneous eruptions. Clin Exp Allergy. 2000a; 30: 847-855.

Yawalkar, N. and W. J. Pichler. Immunohistology of drug-induced exanthema: clues to pathogenesis. Allergy Clin Immunol. 2001a; 1: 299303.

Yawalkar, N. and W. J. Pichler. Pathogenesis of drug-induced exanthema. International Archives of Allergy and Immunology. 2001b; 124: 336-338.

Yawalkar, N., M. Shrikhande, et al. Evidence for a role for IL-5 and eotaxin in activating and recruiting eosinophils in drug-induced cutaneous eruption. J Allergy Clin Immunol. 2000b; 106: 1171-1176. 


\section{Bibliografia consultada:}

Barbau, A. M., M.-C. Bene, et al. (1997). "Role of delayed cellular hypersensitivity and adhesion molecules in amoxicillin-induced morbilliform rashes." Archives of Dermatology 133(4): 481-486.

Barbaud, A., S. Reichert-Penetrat, et al. (1998). "The use of skin testing in the investigation of cutaneous adverse drug reactions." British Journal of Dermatology 139: 49-58.

Bennin, B., J. T. Apgar, et al. (1996). "Guidelines of care for cutaneous adverse drug reactions." J Am Acad Dermatol 35: 458-461.

Bernstein, L. and W. W. Storms (1995). "Pracice parameters for allergy diagnostic testing." Ann Allergy, Asthma and Immunology 75(Dec(part II)): $553-700$.

Blanca, M., S. Posadas, et al. (2000). "Expression of the skin-homing receptor in peripheral blood lymphocytes from subjects with nonimmediated cutaneous allergic drug reactions." Allergy 55(11): 9981004. 
Brockow, K., A. Romano, et al. (2002). "General considerations for skin test procedures in the diagnosis of drug hypersensitivity." Allergy 57(1): $45-51$.

Bruynzeel, D. P. and H. I. Maibach (1997). "Patch testing in systemic drug eruptions." Clin Dermatol 15: 479-484.

Cederbrant, K., V. Stejskal, et al. (1998). "In vitro lymphocyte proliferation in the diagnosis of allergy to phenoxymethylpenicillin." Allergy 53(12): $1155-1161$.

Choquet-Kastylevsky, G., L. Intrator, et al. (1998). "Incresed levels of interleukin-5 are associated with the generation of eosinophilia in druginduced hypersensitivity syndrome." British Association of Dermatology 139(6): 1026-1032.

Crowson, A. N., T. J. Brown, et al. (2003). "Progress in the understanding of the pathology and pathogenesis of cutaneous drug eruptions." Am J Clin Dermatol 4(6): 407-428.

de Haan, P., D. P. Bruynzeel, et al. (1986). "Onset of penicillin rashes: relation between type of penicillin administred and type of immune reactivity." Allergy 41(1): 75-78. 
Depta, J. P. H. and W. J. Pichler (2003). "Cross-reactivity with drugs at the T cell level." Curr Opin Allergy Clin Immunol 3: 261-267.

Dolen, W. K., Ed. (2001). Immunology and Allergy Clinics of North America. Skin testing. Philadelphia.

Gerber, B. O. and W. J. Pichler (2004). "Cellular mechanisms of T cell mediated drug hypersensiticity." Current Opinion in Immunology 16: 732737.

Grammer, L. C. and P. A. Greenberger (2004). "Drug allergy and protocols for management of drug allergies, 3rd edition." Allergy and Asthma Procedures 25(4): 267-272.

Gruchalla, R. (2000). “Understanding drug allergy.” J Allergy Clin Immunol 105: S637-S644.

Jick H: Adverse drug reactions: The magnitude of the problem. J Allergy Clin Immunology 74:555- 1984

Lerch, M. and W. J. Pichler (2004). "The immunological and clinical spectrum of delayed drug-induced exanthems." Curr Opin Allergy Clin Immunol 4: 411-419. 
Mauri-Hellweg, D., M. Zanni, et al. (1996). "Cross-reactivity of T cell lines to beta-lactam antibiotics." The Journal of Immunology 157: 1071-1079.

Neuman, M. G., I. M. Malkiewicz, et al. (2000). "A novel lymphocyte toxicity assay to asses drug hypersensitivity syndromes." Clinical Biochemistry 33(7): 517-524.

Pichler, W. J. (2002). "Pharmacological interaction of drugs with antigenspecific immune receptors: the p-i concept." Curr Opin Allergy Clin Immunol 2: 301-305.

Pichler, W. J., N. Yawalkar, et al. (2002). "Cellular and molecular pathophysiology of cutaneous drug reactions." Am J Clin Dermatol 3(4): 229-238.

Primeau, M.-N. and N. F. Adkinson (2001). "Recent advances in the diagnosis of drug allergy." Curr Opin Allergy Clin Immunol 1: 337-341.

Renn, C. N., W. Straff, et al. (2002). "Amoxicillin-induced exanthema in young adults with infectious mononucleosis: demonstration of drugspecific lymphocyte reactivity." British Journal of Dermatology 147: 11661170. 
Sachs, B., T. Al Masaoudi, et al. (2004). "Combined in vivo and in vitro approach for the characterization of penicillin-specific polyclonal lymphocyte reactivity: tolerance tests with safe penicillins isctead of challenge with the culprit drugs." British Journal of Dermatology 151: 809816.

Sachs, B., S. Erdmann, et al. (2001). "In vitro drug allergy detection system incorporating human liver microsomes in chlorazepate-induced skin rash: drug specific proliferation associated with interleukin-5 secretion." British Journal of Dermatology 144: 316-320.

Sánchez, E., M. J. Torres, et al. (2002). "Adverse drug reactions with an immunological basis: from clinical practice to basic research." Allergy 57(suppl 72): 41-44.

Sarti, W. (1985). "Routine use of skin testing for immediated penicillin allergy to 6764 patients in an outpatient clinic." Ann Allergy 55(2): 157161.

Snodin, D. J. (2004). "Regulatory immunotoxicology: does the published evidence support mandatory nonclinical immune function screening in drug development?" Regulatory Toxicology and Pharmacology 40: 336355. 
Stejskal, V. D. M., R. G. Olin, et al. (1986). "The lymphocyte transformation test for diagnosis of drug-induced occupational allergy." J Allergy Clin Immunol 77: 411-426.

Sullivan, T. J., H. J. Wedner, et al. (1981). "Skin testing to detect penicillin allergy." J Allergy Clin Immunol 68: 171-181. 


\section{Anexo 1:}

\section{Cronograma de visitas:}

\section{Visita 1:}

- Assinatura do termo de consentimento

- Verificação dos critérios de inclusão e exclusão

- História detalhada da exposição prévia e reação adversa ao antibiótico $\beta$ lactâmico

- Informações sobre medicações em uso atualmente, história médica e passado atópico

- Coleta de sangue para realização da pesquisa de IgE e IgG específicas.

- Testes cutâneos de punctura de leitura imediata e posteriormente testes intradérmicos de leitura imediata e tardia quando os primeiros forem negativos: PPL, MDM, amoxicilina (2 mg/ml) e ampicilina (2 $\mathrm{mg} / \mathrm{ml})$.

- Colocação do teste de contato: benzilpenicilina 5000Ul/grama de vaselina, ampicilina 5\% em vaselina e amoxacilina $5 \%$ em vaselina.

\section{Visita 2: ( $48 \mathrm{~h}$ após visita 1 )}

- Remover teste de contato

- Leitura dos testes intradérmicos

- Leitura do teste de contato após 30 minutos de sua retirada

\section{Visita 3: ( 24 horas após visita 2 )}

- Segunda leitura do Teste de contato

- Coleta de sangue para estudo de proliferação linfocitária e dosagem de citocinas. 
Nome:

Data:

Teste Cutâneo com $\beta$-lactâmico:

Data do teste de leitura imediata e leitura:

Data da leitura tardia de 48 horas:

Data da leitura de 72 horas:

\begin{tabular}{|c|c|c|c|c|c|}
\hline & $\begin{array}{l}\mathrm{Du} \\
\text { pla }\end{array}$ & Punctura & $\begin{array}{l}\text { ID } \\
\text { Imediata } \\
20 \text { min }\end{array}$ & $\begin{array}{l}\text { ID leitura tardia } \\
48 \text { horas }\end{array}$ & 72 horas \\
\hline \multirow[t]{2}{*}{$\overline{P P L}$} & 1 & $\begin{array}{l}\text { P: } \\
\text { E: }\end{array}$ & $\begin{array}{l}\text { P: } \\
E:\end{array}$ & $\begin{array}{l}\text { P: } \\
\text { E: }\end{array}$ & $\begin{array}{l}\mathrm{P}: \\
\mathrm{E}:\end{array}$ \\
\hline & 2 & $\begin{array}{l}\text { P: } \\
\text { E: }\end{array}$ & $\begin{array}{l}\text { P: } \\
\text { E: }\end{array}$ & $\begin{array}{l}\text { P: } \\
\text { E: }\end{array}$ & $\begin{array}{l}\text { P: } \\
\text { E: }\end{array}$ \\
\hline \multirow[t]{2}{*}{ MDM } & 1 & $\begin{array}{l}\mathrm{P}: \\
\mathrm{E}:\end{array}$ & $\begin{array}{l}\text { P: } \\
\text { E: }\end{array}$ & $\begin{array}{l}\text { P: } \\
\text { E: }\end{array}$ & $\begin{array}{l}\text { P: } \\
\text { E: }\end{array}$ \\
\hline & 2 & $\begin{array}{l}\text { P: } \\
\text { E: }\end{array}$ & $\begin{array}{l}\text { P: } \\
\text { E: }\end{array}$ & P: & $\begin{array}{l}\text { P: } \\
\text { E: }\end{array}$ \\
\hline \multirow[t]{2}{*}{$\begin{array}{l}\text { Amoxicilina } \\
2 \mathrm{mg} / \mathrm{ml}\end{array}$} & 1 & $\begin{array}{l}\text { P: } \\
\mathrm{E}:\end{array}$ & $\begin{array}{l}\text { P: } \\
\text { E: }\end{array}$ & $\begin{array}{l}\text { P: } \\
\text { E: }\end{array}$ & $\begin{array}{l}\text { P: } \\
\text { E: }\end{array}$ \\
\hline & 2 & $\begin{array}{l}\text { P: } \\
\text { E: }\end{array}$ & $\begin{array}{l}\text { P: } \\
\text { E: }\end{array}$ & $\begin{array}{l}\text { P: } \\
\text { E: }\end{array}$ & $\begin{array}{l}\text { P: } \\
\text { E: }\end{array}$ \\
\hline \multirow[t]{2}{*}{$\begin{array}{l}\text { Ampicilina } \\
2 \mathrm{mg} / \mathrm{ml}\end{array}$} & 1 & $\begin{array}{l}\text { P: } \\
\text { E: }\end{array}$ & $\begin{array}{l}\text { P: } \\
\text { E: }\end{array}$ & $\begin{array}{l}\text { P: } \\
\text { E: }\end{array}$ & $\begin{array}{l}\mathrm{P}: \\
\mathrm{E}:\end{array}$ \\
\hline & 2 & $\begin{array}{l}\text { P: } \\
E:\end{array}$ & $\begin{array}{l}\text { P: } \\
\text { E: }\end{array}$ & $\begin{array}{l}\mathrm{P}: \\
\mathrm{E}:\end{array}$ & $\begin{array}{l}\mathrm{P}: \\
\mathrm{E}:\end{array}$ \\
\hline \multirow[t]{2}{*}{$\begin{array}{l}\text { Controle } \\
\text { Positivo }\end{array}$} & 1 & $\begin{array}{l}\text { P: } \\
\text { E: }\end{array}$ & $\begin{array}{l}\text { P: } \\
\text { E: }\end{array}$ & $\begin{array}{l}\text { P: } \\
\text { E: }\end{array}$ & $\begin{array}{l}\text { P: } \\
\text { E: }\end{array}$ \\
\hline & 2 & $\begin{array}{l}\mathrm{P}: \\
\mathrm{E}:\end{array}$ & $\begin{array}{l}\mathrm{P}: \\
\mathrm{E}:\end{array}$ & $\begin{array}{l}\mathrm{P}: \\
\mathrm{E}:\end{array}$ & $\begin{array}{l}\text { P: } \\
\text { E: }\end{array}$ \\
\hline Negativo & & & & & \\
\hline
\end{tabular}


Nome:

Data:

Teste de Contato com $\beta$-lactâmicos:

\begin{tabular}{|c|c|c|c|c|c|}
\hline No. & Substância & Dupla & $\begin{array}{l}1^{\text {a }} \text { leitura } \\
48 \text { horas }\end{array}$ & $\begin{array}{l}2^{\mathrm{a}} \text { leitura } \\
72 \text { horas }\end{array}$ & $\begin{array}{l}\text { Interpretação } \\
\text { Final }\end{array}$ \\
\hline \multirow[t]{2}{*}{1} & \multirow{2}{*}{$\begin{array}{l}\text { Controle } \\
\text { Negativo }\end{array}$} & 1 & & & \\
\hline & & 2 & & & \\
\hline \multirow[t]{2}{*}{2} & \multirow{2}{*}{$\begin{array}{l}\text { Benzilpenicilina } \\
5000 \mathrm{Ul} / \mathrm{g}\end{array}$} & 1 & & & \\
\hline & & 2 & & & \\
\hline \multirow[t]{2}{*}{3} & \multirow[t]{2}{*}{ Amoxacilina 5\% } & 1 & & & \\
\hline & & 2 & & & \\
\hline \multirow[t]{2}{*}{4} & \multirow[t]{2}{*}{ Ampicilina 5\% } & 1 & & & \\
\hline & & 2 & & & \\
\hline
\end{tabular}




\section{Anexo 2:}

Questionário para investigação de reações a drogas

Nome:

Endereço:

Telefone: Data de Nascimento:

Registro: Data da entrevista:

Forma de Entrevista: $\square$ Direta Telefone

Parte I:

Você já teve uma reação a algum medicamento? Se "sim", passar para parte II.
$\square \operatorname{Sim}$
Não

Parte II:

1) Qual é o nome da primeira medicação a qual você apresentou reação? Nome: $\square$ Nome de fantasia $\square$ Nome genérico $\square$ Não sabe Caso não saiba qual medicação: Para quê o remédio foi receitado? Indicações: $\square$ Antibiótico $\square$ Analgésico $\square$ Outros:

2) Em que ano ocorreu a reação?

Se foi nos últimos 12 meses, especificar o mês:

3) Foi a primeira vez que você usou esta medicação? $\square$ Sim $\quad \square$ Não Se "não": Quanto tempo faz que você a tomou pela última vez? (sem/meses/anos) 
3) Por quanto tempo você tomou a medicação ante do aparecimento da reação?

Dentro das primeiras 4 horas após a primeira dose

Entre 4 e 24 horas depois da primeira dose

- Entre 1 e 3 dias depois do início da medicação

$\square$ Entre 4 e 7 dias depois do início da medicação

Mais de 7 dias depois do início da medicação

Depois do término da medicação $\rightarrow$ Quanto tempo depois? dias

4) A reação incluiu qualquer um dos sintomas?

Sim Não Se "sim": quanto tempo duraram os sintomas? (d/m/a)

Lesões na pele $\rightarrow$ Se "sim" $\rightarrow \square$ Não lembra tipo de lesão

Urticas

Lesões como "sarampo"

lesões planas somente com vermelhidão

úlceras dolorosas em boca, vagina ou reto

Bolhas na pele

Descamação e desprendimento da pele

$\rightarrow$ Isto precisou de internação hospitalar? $₫ \operatorname{Sim}$

Prurido

Febre

Calafrios

Inchaço de lábios, rosto ou boca

Inchaço em algum outro local 
Dor nos músculos ou articulações

Tontura, vertigem ou perda de consciência

Queda da pressão arterial

Espirros ou bloqueio nasal

Náusea, vômito e/ou diarréia

Sensação de aperto no peito, chiado ou falta de ar

$\rightarrow$ Você já foi diagnosticado como asmático? $\square \operatorname{Sim} \quad \square$ Não

Alteração dos exames de sangue $\rightarrow$ Especificar:

6) O que mais você se lembra sobre a reação?

7) Você se lembra de qualquer tratamento que Ihe foi dado além de interromper a droga?

Não

Sim $\rightarrow \square$ Ligação $p$ / resgate $\square$ Procurou pronto socorro $\square$ Contatou seu médico

Qual tratamento você recebeu?

$\square$ adrenalina $\square$ anti-histamínicos

$\square$ corticosteróides $\rightarrow \square$ comprimidos via oral $\square \quad$ EV $\square \quad \mathrm{IM} \rightarrow$ duração:

cremes ou loções

outras medicações: 
8) Quanto tempo demorou para a reação desaparecer completamente?

$\square$ menos de 1 hora $\square 1$ a 24 horas $\square 1$ a 3 dias $\square 4$ a 7 dias $\square$ mais de 7 dias

9) Você tomou esta mesma medicação novamente depois da reação? Não

$\square \operatorname{Sim} \rightarrow$ a) quando (dias, meses, anos) depois

b) o que aconteceu? $\square$ não ocorreu reação $\square$ ocorreu uma reação similar reação diferente $\rightarrow$ descreva:

10) Avaliação do entrevistador

Sua impressão sobre a confiabilidade dos dados apresentados pelo paciente:

$\square$ Boa $\quad \square$ Satisfatória $\quad \square$ Ruim

Esta reação foi compatível com uma reação imunológica por droga?

$\square$ Não (marque um ou mais abaixo) $\square$ Sim

Reação adversa/tóxica $\quad \square \operatorname{lgE}$ dependente

Intolerância $\square$ citotóxica ou imunocomplexo

Overdose (incluindo dça soro-tipo II e III)

Pseudoalérgica/ldiossincrasia $\square$ Cél. T dependente (tipo IV)

Não relacionada à droga $\quad \square$ outra não classificada

$\square$ Outras: 
Como você classificaria a gravidade desta reação?

Leve (sem necessidade de cuidados médicos ou tratamento)

$\square$ Moderada $\square$ Grave (risco de vida potencial ou incapacidade ou prolongada)

O quanto você está confidente de que a reação acima foi ou não foi imunológica em sua origem?

$\square$ Muito confidente $\square$ Moderadamente confidente $\quad \square$ Incerto Parte III:

Agora, nós gostaríamos de fazer algumas perguntas sobre sua exposição prévia a alguns medicamentos comuns:

1) Quantas vezes você foi tratado com antibióticos durante toda sua vida?

$\square$ Nenhum $\square 1$ a $3 \quad \square 4$ a $10 \quad \square 10$ a $25 \quad \square$ mais que 25

2) Quantos cursos de penicilina você já tomou durante toda sua vida?

$\square$ Nenhum $\square 1$ a $3 \quad \square 4$ a $10 \quad \square 10$ a $25 \square$ mais que 25

3) Quantos cursos de antibióticos diferente de penicilina você já tomou em toda sua vida?

$\square$ Nenhum $\square 1$ a $3 \quad \square 4$ a $10 \quad \square 10$ a $25 \quad \square$ mais que 25

4) Quantas vezes você tomou qualquer antibiótico nos últimos 5 anos?

$\square$ Nenhum $\square 1$ a $3 \quad \square 4$ a $10 \quad \square 10$ a $25 \quad \square$ mais que 25

5) Quantas vezes você tomou penicilina nos últimos 5 anos?

$\square$ Nenhum $\square 1$ a $3 \quad \square 4$ a $10 \quad \square 10$ a $25 \quad \square$ mais que 25

6) Quantas vezes você tomou antibióticos diferentes de penicilina nos últimos 5 anos?

$\square$ Nenhum $\square 1$ a $3 \quad \square 4$ a $10 \quad \square 10$ a $25 \quad \square$ mais que 25 
7) Você já tomou uma única medicação continuamente por 5 anos ou mais? $\square \operatorname{Sim} \square$ Não

Se "não", vá para o item 8. Se "sim", diga os nomes destas medicações, por quantos anos você as tomou ou está tomando, e a doença para qual ela foi indicada:

\begin{tabular}{|l|l|l|}
\hline Medicação & Duração (anos) & Indicação Médica \\
\hline & & \\
\hline & & \\
\hline & & \\
\hline & & \\
\hline & & \\
\hline & & \\
\hline & & \\
\hline & & \\
\hline
\end{tabular}


8) Você já tomou uma única medicação continuamente por mais de 1 anos, mas menos de 5 anos? $\square \operatorname{Sim} \quad \square$ Não

Se"não", vá para o final. Se "sim", diga os nomes destas medicações, por quantos anos você as tomou ou está tomando, e a doença para qual ela foi indicada:

\begin{tabular}{|l|l|l|}
\hline Medicação & Duração (anos) & Indicação Médica \\
\hline & & \\
\hline & & \\
\hline & & \\
\hline & & \\
\hline & & \\
\hline & & \\
\hline & & \\
\hline & & \\
\hline
\end{tabular}

Entrevistador:

Paciente: 


\section{Anexo 3}

Tabela 8a: Resultados dos testes cutâneos de leitura tardia, teste de contato, proliferação linfocitária, IgE sérica específica, Dosagem de citocinas no sobrenadante da cultura linfocitária (pacientes $n=20$ )

\begin{tabular}{|c|c|c|c|c|c|c|c|c|}
\hline & Paciente & $T C I D$ & $T C$ & $L T T$ & IgE especiffica & IFN-gama & TNF-alfa & $I L-5$ \\
\hline LBRP & 1 & neg & neg & neg & neg & positivo & neg & neg \\
\hline JSC & 2 & neg & neg & positivo & neg & neg & positivo & neg \\
\hline MRAR & 3 & neg & neg & positivo & neg & neg & positivo & neg \\
\hline $\mathrm{RCL}$ & 4 & positivo & positivo & positivo & neg & positivo & positivo & positivo \\
\hline ASN & 5 & neg & neg & positivo & neg & neg & positivo & neg \\
\hline$G$ & 6 & neg & neg & positivo & neg & neg & positivo & neg \\
\hline VMGG & 7 & neg & neg & neg & neg & neg & positivo & neg \\
\hline $\mathrm{MB}$ & 8 & neg & neg & neg & neg & neg & positivo & neg \\
\hline WSF & 9 & neg & neg & neg & neg & positivo & positivo & positivo \\
\hline APG & 10 & positivo & positivo & neg & neg & neg & positivo & neg \\
\hline VMMP & 11 & neg & neg & positivo & $N R$ & positivo & positivo & positivo \\
\hline HGMC & 12 & neg & neg & positivo & neg & positivo & positivo & positivo \\
\hline $\mathrm{CO}$ & 13 & neg & neg & positivo & neg & neg & positivo & neg \\
\hline MRC & 14 & neg & neg & neg & neg & neg & positivo & neg \\
\hline MLNS & 15 & neg & neg & neg & neg & neg & positivo & neg \\
\hline MCSP & 16 & neg & neg & neg & neg & neg & positivo & neg \\
\hline WOF & 17 & positivo & positivo & positivo & neg & positivo & positivo & positivo \\
\hline Lisandra & 18 & neg & neg & positivo & neg & neg & positivo & neg \\
\hline MAGJ & 19 & neg & neg & neg & neg & positivo & positivo & positivo \\
\hline DV & 20 & neg & neg & neg & neg & neg & positivo & neg \\
\hline
\end{tabular}

TCID: teste cutâneo intradérmico

TC: teste de contato

LTT: lymphocyte transformation test (proliferação linfocitária)

NR: não realizado 
Tabela 8a: Resultados dos testes cutâneos de leitura tardia, teste de contato, proliferação linfocitária, lgE sérica específica, Dosagem de citocinas no sobrenadante da cultura linfocitária (controles $n=15$ )

\begin{tabular}{|c|c|c|c|c|c|c|c|c|}
\hline & Controle & $T C I D$ & $T C$ & LTT & $\begin{array}{c}\text { lgE } \\
\text { específica }\end{array}$ & IFN-gama & TNF-alfa & IL-5 \\
\hline DS & 1 & neg & neg & positivo & neg & neg & neg & neg \\
\hline LKT & 2 & neg & neg & neg & neg & positivo & positivo & neg \\
\hline LCD & 3 & neg & neg & neg & neg & neg & positivo & neg \\
\hline FP & 4 & neg & neg & neg & neg & neg & neg & neg \\
\hline MFM & 5 & neg & neg & neg & neg & neg & positivo & neg \\
\hline AKBO & 6 & neg & neg & neg & neg & neg & positivo & neg \\
\hline MD & 7 & neg & neg & neg & neg & neg & positivo & neg \\
\hline DBV & 8 & neg & neg & neg & neg & neg & positivo & neg \\
\hline $\mathrm{AO}$ & 9 & neg & neg & neg & neg & neg & positivo & neg \\
\hline DCM & 10 & neg & neg & neg & neg & neg & positivo & neg \\
\hline Genair & 11 & neg & neg & neg & neg & neg & positivo & neg \\
\hline Rosana & 12 & neg & neg & neg & neg & neg & neg & neg \\
\hline $\begin{array}{l}\text { Ana } \\
\text { Lúcia }\end{array}$ & 13 & neg & neg & neg & neg & neg & neg & neg \\
\hline JMG & 14 & neg & neg & neg & neg & neg & neg & neg \\
\hline MSS & 15 & neg & neg & positivo & neg & neg & neg & neg \\
\hline
\end{tabular}

TCID: teste cutâneo intradérmico

TC: teste de contato

LTT: lymphocyte transformation test (proliferação linfocitária)

NR: não realizado 